\title{
Sustaining Biodiversity and Ecosystem Services in the Hindu Kush Himalaya
}

\author{
Coordinating Lead Authors \\ Jianchu $\mathrm{Xu}$, World Agroforestry Centre, East and Central Asia Regional Programme; Kunming Institute of \\ Botany, Kunming Yunnan Province, P.R. China, e-mail: J.C.Xu@cgiar.org; jxu@mail.kib.ac.cn \\ Ruchi Badola, Wildlife Institute of India, Chandrabani, Dehra Dun, Uttarakhand, India, \\ e-mail: ruchi@wii.gov.in \\ Nakul Chettri, International Centre for Integrated Mountain Development, Kathmandu, Nepal, \\ e-mail: Nakul.Chettri@icimod.org (corresponding author)
}

\section{Lead Authors}

Ram P. Chaudhary, Research Center for Applied Sciences \& Technology (RECAST), Tribhuvan University, Kirtipur, Kathmandu, Nepal, e-mail: ram@cdbtu.wlink.com.np

Robert Zomer, World Agroforestry Centre, East and Central Asia Regional Programme; Kunming Institute of Botany, Kunming Yunnan Province, P.R. China, e-mail: r.zomer@mac.com

Bharat Pokhrel, HELVETAS, Swiss Inter-cooperation Nepal, Programme Coordination Office, Lalitpur,

Kathmandu, Nepal, e-mail: bharat.pokharel@ helvetas.org.np

Syed Ainul Hussain, Wildlife Institute of India, Chandrabani, Dehra Dun, Uttarakhand, India,

e-mail: hussain@wii.gov.in

Sunita Pradhan, Ashoka Trust for Research in Ecology and the Environment, Regional Office Eastern Himalaya, Gangtok, Sikkim, e-mail: sunita.pradhan@atree.org

Rebecca Pradhan, Royal Society for Protection of Nature, Thimphu, Bhutan,

e-mail: rebecca.pradhan@gmail.com

\section{Contributing Authors}

Pratikshya Kandel, International Centre for Integrated Mountain Development, Kathmandu, Nepal, e-mail: pratikshya.kandel@icimod.org

Kabir Uddin, International Centre for Integrated Mountain Development, Kathmandu, Nepal, e-mail: kabir.uddin@icimod.org

Pariva Dobriyal, Wildlife Institute of India, Chandrabani, Dehra Dun, Uttarakhand, India, e-mail: pariva@wii.gov.in

Upma Manral, Wildlife Institute of India, Chandrabani, Dehra Dun, Uttarakhand, India, e-mail: upma@wii.gov.in

Amanat K. Gill, Wildlife Institute of India, Chandrabani, Dehra Dun, Uttarakhand, India, e-mail: amanat@wii.gov.in

Uma Partap, International Centre for Integrated Mountain Development, Kathmandu, Nepal, e-mail: uma.partap@icimod.org

Kamal Aryal, International Centre for Integrated Mountain Development, Kathmandu, Nepal, e-mail: kamal.aryal@icimod.org

\section{Review Editors}

Sarala Khaling, Ashoka Trust for Research in Ecology and the Environment, Regional Office Eastern Himalaya, Gangtok, Sikkim, e-mail: sarala.khaling@atree.org

Yan Zhaoli, Chengdu Institute of Biology, Chinese Academy of Sciences, Chengdu, China, e-mail: zhaoliy@cib.ac.cn

S.P. Singh, Central Himalayan Environment Association (CHEA) Nainital, Uttarakhand, India, e-mail: singh.js1@gmail.com

\section{Corresponding Author}

Nakul Chettri, International Centre for Integrated Mountain Development, Kathmandu, Nepal, e-mail: Nakul.Chettri@icimod.org 


\section{Contents}

Chapter Overview

5.1 Mountain Biodiversity and Ecosystem Services: A Major Global Asset Under Threat 131

5.2 The Rich Biodiversity of the HKH Region

5.2.1 Ecosystem Diversity

5.2.2 Species Diversity

5.2.3 Genetic Diversity

5.2.4 Functional Diversity

5.3 Ecosystem Services-The Source of Human Wellbeing .................................................... 138

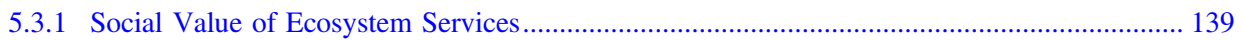

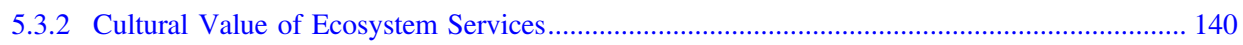

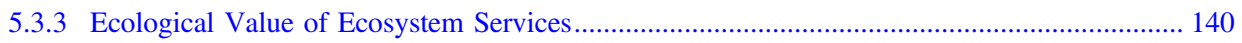

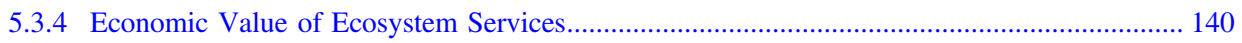

5.3.5 Changing Ecosystem Services of the HKH Region ............................................................ 141

5.3.6 Trade-offs and Synergies - Implications for Development .................................................. 143

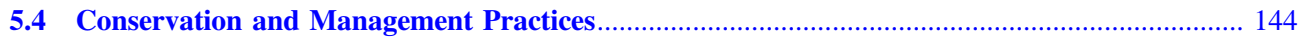

5.4.1 Flagship and Keystone Species Conservation ...................................................................... 145

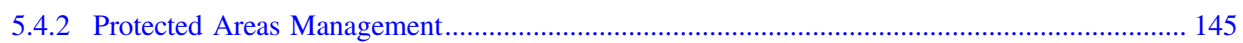

5.4.3 Conservation Through Traditional Knowledge ..................................................................... 145

5.4.4 The Landscape Approach — Recognizing Complexity and Understanding Linkages ............... 149

5.4.5 Participatory Forest Resources Management Practices ......................................................... 150

5.4.6 National and International Policies and Legislations-Support for Biodiversity

Conservation

5.5 Sustaining Ecosystems - Challenges, Opportunities, and Strategies.

5.5.1 An Integrated Approach - The Landscape as a Socio-Ecological System ............................. 154

5.5.2 Building Knowledge — Science in Support of Decision-Making ............................................. 155

5.5.3 Regional Cooperation for Regional Challenges and Opportunities ....................................... 155

5.5.4 National and Global Investment-Securing Future of Biodiversity and Ecosystem Services.

\section{Chapter Overview}

\section{Key Findings}

1. The mountain ecosystems of the Hindu Kush Himalaya (HKH) are diverse with one of the highest diversity of flora and fauna providing varied ecosystem services to one fourth of humanity. With four out of 36 global biodiversity hotspots the HKH is a cradle for $35,000+$ species of plants and 200+ species of animals. At least 353 new species-242 plants, 16 amphibians, 16 reptiles, 14 fish, two birds, and two mammals, and at least 61 invertebrates - have been discovered in the
Eastern Himalaya between 1998 and 2008, equating to an average of 35 new species finds every year.

2. The HKH has numerous seeds of good practices in conservation and restoration of degraded habitat along with community development which need upscaling and out scaling. These participatory and community-based approaches have had large ecological, economic, and social positive impacts. Substantial degraded forest areas are regenerating, as decentralized practices reverse deforestation trends. Local communities have gained institutional space to decide for themselves 
on issues related to forests, income, inclusion, and social justice.

3. Global and regional drivers of change on biodiversity and ecosystem loss are prevalent and increasing in the HKH. These drivers include land use and land cover change, pollution, climate change, invasive species, solid waste, habitat degradation, and overexploitation of resources, among others, impacting biodiversity, ecosystem services, and human wellbeing.

\section{Policy Messages}

1. Regional efforts will enhance the resilience of HKH ecosystems to extreme events while conserving biodiversity and promoting sustainable development. Climate change and other drivers are altering the structure and population of some $\mathrm{HKH}$ ecosystems and species, including their distribution range, with risks to biodiversity and resilience. Because many of these critical HKH ecosystems are transnational, regional cooperation is essential for translating conservation and development challenges into sustainable development opportunities. Attaining the Sustainable Development Goals (SDGs) will depend on such cooperation.

2. The mountain ecosystems of the HKH need an integrated and transboundary ecosystem approach at the landscape scale for conservation and sustainable development. It should be managed as a mosaic of integrated socio-ecological systems across political boundaries. Efforts are needed to build on existing traditional practices, promote regional cooperation, and increase national and global investments.

3. Investments in mountain ecosystems should be made where they are most needed to conserve biodiversity, alleviate poverty, and enhance sustainable livelihoods. A large population in the $\mathrm{HKH}$ region still lives in poverty and is highly dependent on ecosystem services for livelihoods, especially in remote areas and developing nations. Because of varying priorities and resource availability, HKH countries are at different levels of investment in managing the mountain ecosystems. Therefore, more investment should be set aside for enhancing resilience with win-win trade-offs in the remote areas and developing countries.
Mountains make up $24 \%$ of the world's land area, are home to $20 \%$ of the world's population, provide $60-80 \%$ of the world's fresh water, and harbour $50 \%$ of the world's biodiversity hotspots (well-established). The United Nations recognized the importance of mountain ecosystems, both for conserving biological diversity and for sustaining humanity, in Chap. 13 of Agenda 21. More generally, ecosystem diversity, species diversity, genetic diversity, and functional diversity all play key roles in the ecosystem services that benefit people and communities (well-established).

All these types of diversity are fundamental for the mountains of the HKH. With its unique high mountains and numerous micro climates, the HKH contains varied ecological gradients that set the stage for species evolution. The result is the youngest global mountain biome and one of the most ecologically diverse ecosystems in the world (wellestablished). Between 1998 and 2008, an average of 35 new species were discovered each year in the Eastern Himalaya alone (well-established).

The ecological diversity of the HKH has long been modified by extraction, trade, culture, and land use (established but incomplete). Of the region's population, 70-80\% live in rural areas, while 60-85\% subsist directly through ecosystem services (well-established). Now, however, the region is being subjected to pressures that are more aggressively unfriendly to ecosystems. Climate change is one of these pressures; unprecedented development is another (established but incomplete).

Global and regional drivers of biodiversity loss — such as land use change and habitat loss, pollution, climate change, and invasive alien species - are prevalent and increasing in the HKH (established but incomplete). For example, by the year 2100 the Indian Himalaya could see nearly a quarter of its endemic species wiped out (inconclusive). Countries in the region already place a premium on functional ecosystems and ecosystem services: more than $39 \%$ of all land in the HKH lies within a protected area network (well-established). Even so, ecosystems are in stress or subject to risks from a changing climate, from varying government policies, and from expanding markets - at all levels (established but incomplete).

Broadly, ecosystem services have four kinds of value:

- Social-for public benefit

- Cultural-for aesthetic and communal significance

- Ecological-for environmental conservation and sustainability

- Economic-for livelihoods through goods and services production. 
We generally know less about social and cultural value in the HKH than about ecological and economic value (established but incomplete). All four kinds of value, however, have received little attention - either qualitative or quantitative - compared with such widely researched topics in the region as carbon, water, and hydropower (wellestablished). For example, recreation is a growing principal livelihood activity in the Himalaya. Some analyses acknowledge the positive economic gains, but also negative impacts on biodiversity and ecosystem services (established but incomplete). However, many of these studies focus on a small area and lack the holistic view needed to inform policy decisions (well-established).

Better management of $\mathrm{HKH}$ ecosystem services entails learning more about the state and trends of coupled socio-ecological systems. The diverse landscapes of the region provide multiple services with complex, dynamic interrelations. Some studies based on integrated systems analysis (most emerging from hydrology and geology) have traced upstream-downstream links at both the catchment and the basin scale. Common drivers, affecting multiple ecosystem processes and interactions among ecosystem services, can create both synergies and trade-offs between ecosystem health and the flow of services (established but incomplete). Trade-off analysis is thus critical for integrating ecosystem services into landscape planning, management, and decision making-especially in looking at alternate paths to sustainable land use (well-established).

Recent decades have seen considerable development in concepts of biodiversity conservation-from perspectives that focused on species while excluding people, to new approaches centred on people and communities (wellestablished). As a result, biodiversity conservation in the $\mathrm{HKH}$ has changed along with natural resource management. Participatory models have emerged and been accepted in various sectors, with the region generally adopting the 'ecosystem approach' advocated by the United Nations Convention on Biological Diversity (1992). Traditional ecological knowledge, beliefs, and culture have contributed substantially towards meeting conservation goals (estab-

\section{lished but incomplete).}

These participatory and community-based approaches have had large ecological, economic, and social positive impacts. Substantial degraded forest areas are regenerating, as decentralized practices reverse deforestation trends. Local communities have gained institutional space to decide for themselves on issues related to forests, income, inclusion, and social justice. As people make their own decisions rather than reacting to orders from government officials, rural residents have been able to avail themselves of more local economic opportunities. Progressive policies have driven this paradigm shift (established but incomplete).
And yet the challenges facing the region could have cascading effects, especially for communities highly dependent on ecosystem services (established but incomplete). The transformative changes to date were driven mainly by a changing climate and land use change. As a result, changes to production systems are required to address potential resource crises arising from a growing population and increasing demand. Special attention must now be paid to governance effectiveness and implementation of evolving policies (established but incomplete).

Despite successes in community-based conservation and development, conserving the global assets of the HKH remains a challenge (established but incomplete). The $\mathrm{HKH}$ ecosystems provide crucial ecosystem services to 1.9 billion people, more than any other mountain system (well-established). As they continue to provide these services both within and outside the region, how can their biodiversity be sustained and the continued flow of services assured? The solution will be to manage the $\mathrm{HKH}$ as a mosaic of integrated socio-ecological systems across political and sectoral boundaries, linking upstream and downstream conservation action with local climate adaptation strategies (established but incomplete).

We still need to improve our understanding of biodiversity and ecosystem functions and services in the HKH (wellestablished). Only with improved technical knowledge, policies, and practices can environmental security be assured. It should also be strengthened through integration of traditional practices with science-based conservation, regional cooperation, and national and global investments (established but incomplete).

\section{Biodiversity, Ecosystems and the Sustainable Development Goals}

Building the social and ecological resilience of $\mathrm{HKH}$ mountain ecosystems will be essential for attaining Sustainable Development Goal (SDG) 15: Protect, restore and promote sustainable use of terrestrial ecosystems, sustainably manage forests, combat desertification, and halt and reverse land degradation and halt biodiversity loss. Most specifically relevant is Target 15.4: "By 2030, ensure the conservation of mountain ecosystems, including their biodiversity, in order to enhance their capacity to provide benefits that are essential for sustainable development."

In addition, sustaining the flow of HKH ecosystem services can help attain SDGs 1 (alleviating poverty), SDG 2 (zero hunger), SDG 5 (addressing gender and social equity), SDG 6 (water, sanitation, and water for productive purposes), and SDG 7 (access to clean energy). Here, inclusive and transformative change is 
needed-recognizing the role of mountain communities in providing ecosystem services, adding new incentives, generating opportunities. Policies should develop and support markets for mountain niche products, and should enable investment in the mountains.

\subsection{Mountain Biodiversity and Ecosystem Services: A Major Global Asset Under Threat}

Mountains make up $24 \%$ of the world's land area, are home to $20 \%$ of the world's population, provide $60-80 \%$ of the world's freshwater, and harbour $50 \%$ of globally recognized biodiversity hotspots (Mittermeier et al. 2004; Rodríguez-Rodríguez et al. 2011; Maselli 2012). Mountain ranges act as barriers to some organisms and bridges to others, and therefore facilitate species isolation, speciation, extinction, and migration (Körner and Ohsawa 2005). The mountain ecosystems provide key livelihood resources such as food, timber, fibre, and medicine and a wide range of services such as fresh air and water, climate regulation, carbon storage, and the maintenance of aesthetic, cultural, and spiritual values (Grêt-Regamey et al. 2008; Schild 2008; Bhat et al. 2013; Sandhu and Sandhu 2014; Ahmad and Nizami, 2015; Hamilton 2015). The natural and semi-natural vegetation cover on mountains helps to stabilize headwaters, prevent flooding, and maintain steady year-round flows of water by facilitating the seepage of rainwater into aquifers, vital for maintaining human life in the densely populated areas downstream. As a result, mountains have often been referred to as 'water towers' (Schild 2008; Mukherji et al. 2015; Molden et al. 2016). Recognizing the importance of mountains for biodiversity and sustaining ecosystem services, Chap. 13 of Agenda 21 (1992) has recognized mountains as a significant habitat for support of all forms of living organisms, animals (including humans), and plants (UN 1992).

Driven by plate tectonics, the mountains of the HKH have unique ecosystems with altitudinal variation giving rise to numerous micro climates and diverse ecological gradients. The HKH is the youngest and one of the most diverse ecosystems among the global mountain biomes, with extreme variations in vegetation, climate, and ecosystems resulting from altitudinal, latitudinal, and soil gradients $(\mathrm{Xu}$ et al. 2009a; Sharma et al. 2010). This diverse biophysical habitat sets the stage for a rich biodiversity and species evolution (Miehe et al. 2014; Hudson et al. 2016). The region is the source of 10 major river systems with productive landscapes and strong upstream downstream linkages (Xu et al. 2009a), and includes all or part of four global biodiversity hotspots-Himalaya, Indo-Burma, mountains of Southwest China, and mountains of Central Asia (Mittermeier et al. 2004; Chettri et al. 2010)—which contain a rich variety of gene pools and species with high endemism and novel ecosystem types (Fig. 5.1.) In addition, the region supports more than 60 different ecoregions, many of them Global 200 ecoregions (Olson and Dinerstein 2002). The ecosystem services from the HKH sustain 240 million people in the region and benefit some 1.7 billion people in the downstream river basin areas (see Box 1.1) and have been well recognized by many scholars (Quyang 2009; Xu et al. 2009a; Molden et al. 2014a; Sharma et al. 2015).

The natural and semi-natural landscapes of the HKH have been altered, modified, and influenced by human history, culture, and traditional practices for thousands of years (Deterra 1937; Ives and Messerli 1989; Goldewijk et al. 2010, 2011; Ellis 2015). The HKH has witnessed human intervention since circa 5000 years BP, bringing crop diversity, cattle farming, and cultural congruence from east and west and leading to the creation of dynamic landscapes (Gurung 2004a; Miehe et al. 2009, 2014; Chen et al. 2015a). These dynamic landscapes have brought higher biological diversity through use, diversification, and promotion of plants, animals, agrobiodiversity, and traditional knowledge (Xu et al. 2005; Uprety et al. 2016). The diverse social networks across the region and rapid development of trade facilitated the exchange of cultures, knowledge, and materials (Chaudhary et al. 2015a, b). They evolved into coupled socio-ecological systems which have been significant not only for the people living in the mountain areas, but also for those beyond who benefit from the ecosystem services (Blaikie and Muldavin 2004; Nepal et al. 2014a, b).

The HKH is now being subjected to further change, including climate change (Shrestha et al. 2012) and unprecedented development that is environmentally unfriendly (Pandit et al. 2007; Grumbine and Pandit 2013; Xu and Grumbine 2014a). There are examples of both negative and positive impacts of the various drivers resulting in change in wildlife population, plant phenology, and ecosystem productivity across the region (Bawa and Seidler 2015; Singh and Borthakur 2015; Chaudhary et al. 2016a, b). Moreover, an increase in the number and severity of natural disasters as well as a breakdown of traditional systems of management is an indicator of the decreasing resilience of the HKH system (Elalem and Pal 2015). Global drivers of biodiversity loss, namely land use land cover change, habitat change, overexploitation, pollution, invasive alien species, and climate change, are prevalent in the HKH (Maxwell et al. 2016) and are increasing (Chettri and Sharma 2016). Solid waste management and haphazard development are bringing additional challenges (Kala 2014; Posch et al. 2015). Although there are a number of examples of best practices in community-based 


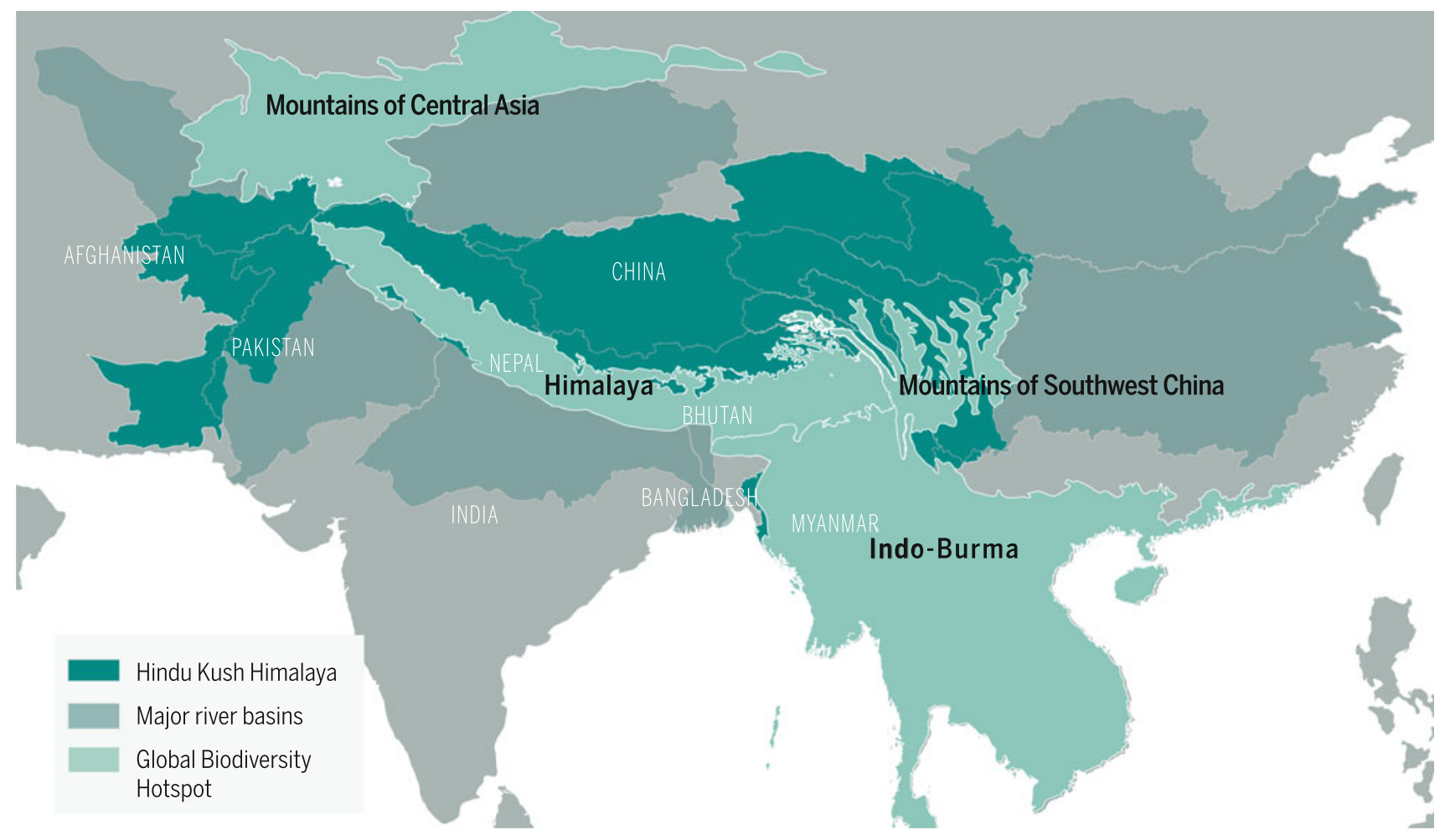

Fig. 5.1 Four global biodiversity hotspots and 10 river basins of the HKH

conservation and development initiatives, the challenges still exist in terms of good governance (Pai and Dutta 2006; Sharma et al. 2010). Sectoral and piecemeal approaches are among the limiting factors as they do not create many incentives for local communities to conserve biodiversity and water resources (Rasul 2014). Despite this, the Himalaya continue to provide ecosystem services that sustain societies both within the region and beyond. The diverse cultures and traditions manifested by over 1,000 ethnic groups (Turin 2005) continue to nurture the ecosystems at various spatial scales. In addtion, innovative practices have also promoted the production, restoration, and conservation of ecosystems and the services that they provide (Banskota et al. 2007; Sharma et al. 2007a, b, c; Aase et al. 2013).

In order to ensure the sustainability of ecosystems and continuity of ES, it is critical that biodiversity be managed as a mosaic of integrated socio-ecological systems. This should encompass systems across political and sectoral boundaries, and link upstream and downstream conservation action with local climate adaptation (Xu and Grumbine 2014a). To gain a better knowledge of the ecosystem services that people depend on for benefits and values, it is necessary to understand the state and dynamics of biodiversity and ecosystem functions. This understanding could be strengthened through deeper understanding of traditional practices and integrated with science-based conservation, regional cooperation, and national and global investments on policy and practices for environmental security (Fig. 5.2). In this chapter we move forward with this integrated approach to biodiversity conservation and ecosystem services and try to visualize their provision spatially and temporally. The content is basically drawn from learning and good practices from the past and lessons from the present, and we try to sow seeds for the sustainability of these services in the future with recommendations for future policy and practice.

Due to the extremely wide scope of the chapter and large volume of literature available, we have attempted to focus only on the key thematic areas of biodiversity and ecosystem services, with some examples to illustrate the trends observed across the HKH. We have structured our chapter to (1) contextualize the state of biodiversity and ecosystem status; (2) highlight the status and trends in biodiversity and ecosystem services; (3) document the current state of the coupled socio-ecological system; (4) highlight conservation and management practices; and (5) identify gaps and suggest strategic directions for mountain sustainability.

\subsection{The Rich Biodiversity of the HKH Region}

The Convention on Biological Diversity gives a formal definition of biodiversity in Article 2: "biological diversity means the variability among living organisms from all sources including, inter alia, terrestrial, marine, and other 
Fig. 5.2 Linkages between ecosystems, biodiversity, and human wellbeing (adapted from de Groot et al. 2010)
Integrated socio-ecological systems

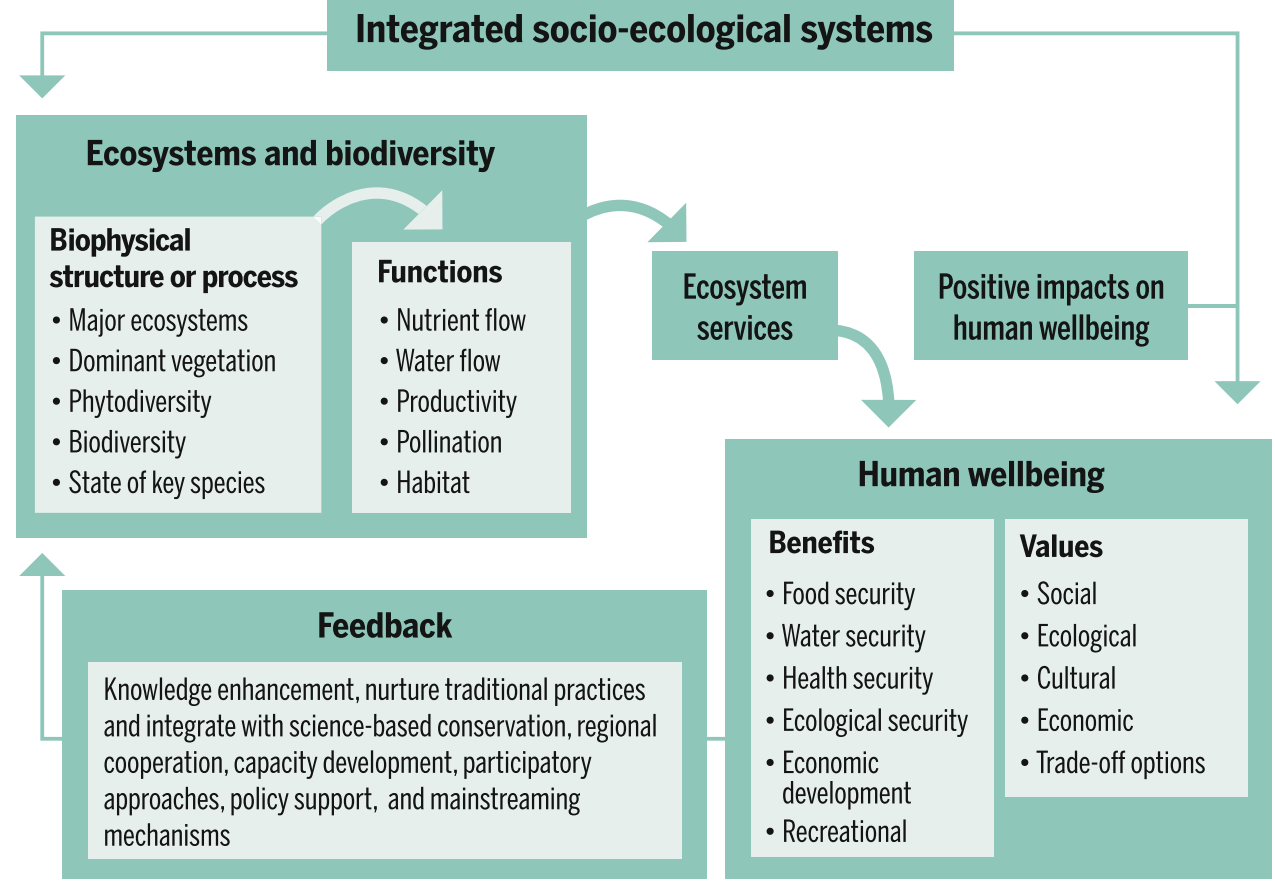

aquatic ecosystems and the ecological complexes of which they are part; this includes diversity within species, between species, and of ecosystems". The HKH exhibits high levels of diversity and heterogeneity, partly in response to the high climatic variability and rugged topography. Very high levels of biodiversity and species richness (Myers et al. 2000; Sharma et al. 2010; Zomer and Oli 2011) are the result of a combination of several biophysical and geographical factors (Ives and Messerli 1989; Miehe et al. 2015a), including altitudinal zonation along a long and steep elevation gradient that ranges from near sea level at the base of the foothills up to the highest mountains in the world, with a prominent rain shadow zone on the Tibetan Plateau; a moisture and precipitation gradient that goes from generally wetter in the east to semi-arid and drier zones in the west; and the blocking effect of the high mountain barrier which allows tropical conditions to flourish in deep valleys by blocking cold continental northern winds from protruding further south, even though physically these mountains are outside the tropics. Rainfall in the HKH is primarily fed by the Indian summer monsoon, which weakens as it moves from the eastern reaches of the Himalaya northwest towards the Hindu Kush, and by winter storms which bring moisture in from the Arabian Sea (Barlow et al. 2005). The interaction of these two main precipitation regimes with the altitudinal gradient results in pronounced spatial, but also temporal, gradients in temperature and precipitation throughout the $\mathrm{HKH}$, and consequently high levels of ecosystem diversity.

Additionally, the steep slopes of the HKH have high levels of erosion (Ives and Messerli 1989), which provide nutrient-rich sediments that help to sustain ecosystem flow to the 10 Asian river basins emanating from these highland water towers and impact the agricultural productivity of the floodplains. Equally, the high levels of erosion also result in habitat degradation and biodiversity loss (Xu et al. 2009a).

The mountain building, driven by plate tectonics, have created a diverse landscape, climate variability, ecological gradients, and physical habitats that set the stage for ecosystem differentiation (Hua 2012) and species evolution (Hoorn et al. 2013; Tremblay et al. 2015). The initial uplift of the Himalayan and Hindu Kush ranges from the mid to late Eocene, and the more recent (early Pliocene) uplift of the Hengduan Mountains, have enabled the development of a large number of recognized 'biodiversity hotspots' (Hughes and Atchison 2015; Mittermeier et al. 2015; Rodríguez-Rodríguez et al. 2011). The high levels of species richness found here are derived from both endemic speciation from local ancestors and migration of organisms from distant locales, noting that this region represents a congruence of two different floristic realms (Palearctic and Indomalayan) (Olson and Dinerstein 2002). Likewise, the region is also one of the most productive and intensively cultivated mountain regions in the world, with a high population density and ethnic diversity, which likewise has led to high levels of agrobiodiversity, farming system and agro-ecosystem differentiation, and domestication of many important food plants and animals (Gorenflo et al. 2012; Pandit et al. 2014; Karan 2015).

The bioclimatic zones range from hot tropical moist to lush green and humid valleys in the central and eastern midhills along the ranges, extensive mountain forests, 


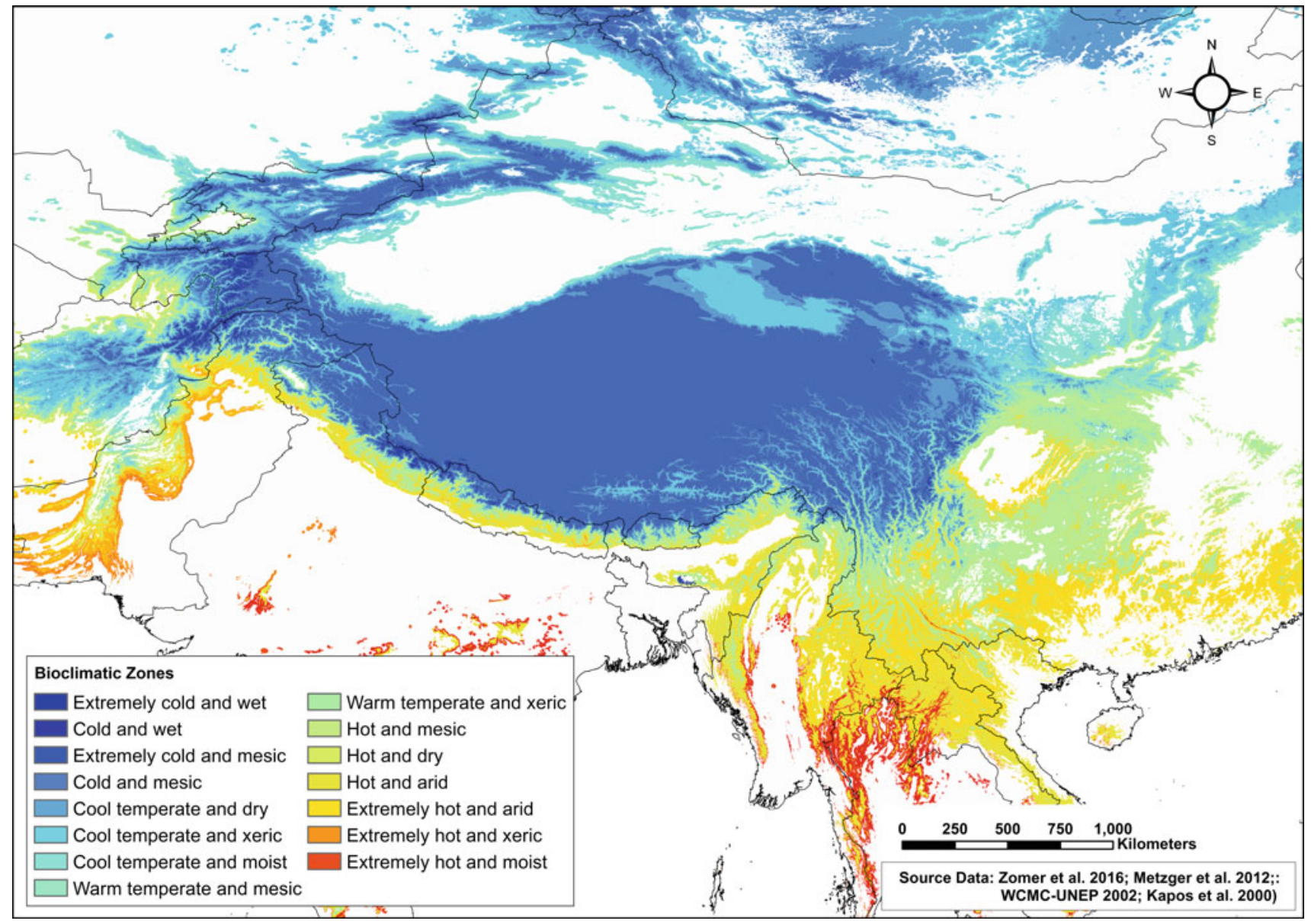

Fig. 5.3 Major bioclimatic zones, based on the Global Environmental Stratification (Metzger et al. 2013), found within the mountainous and highland regions of Asia. Mountains and highland areas are identified based on Kapos et al. (2000) using data from WCMC-UNEP (2002)

moist alpine meadows, remote and arid trans-Himalayan valleys, the cold Tibetan Plateau and vast areas of high altitude grasslands and steppe, and arid and semi-arid regions in the west, as well as extensive areas of permanent snow and ice. Zomer et al. (2016) found that 105 of 125 bioclimatic strata worldwide (Metzger et al. 2013), each representing a broad set of unique but homogenous bioclimatic conditions, were found within the HKH and its associated downstream river basins (Fig. 5.3). This bioclimatic and geographic heterogeneity has given rise to an array of ecosystems, biomes, and forest types (ranging from moist tropical broadleaf to temperate oak forests, alpine conifers, alpine pastures, and high altitude grasslands) providing habitat for a diversity of wildlife (including tiger, Asian elephant, musk deer, blue sheep, snow leopard, Tibetan antelope, and many other rare and endangered species). Many of the highest levels of diversity worldwide, in terms of plants and animals, are found in these mountain ranges, in three major global biodiversity
hotspots-Himalaya, Indo-Burma, and the mountains of Southwest China (Allen et al. 2010). This area represents an important habitat for a high proportion of endemic and threatened mammals (Hoffmann et al. 2010); fish, molluscs, and dragonflies (Allen et al. 2010); birds (Dunn et al. 2016); and agrobiodiversity (Chettri et al. 2010), for which the HKH is renowned.

The Indo-Burma hotspot is one of the most significant hotspots, with rich diversity and a high proportion of endemism (Table 5.1). However, high levels of endemism are found throughout these mountains (Myers et al. 2000) amongst a vast array of plants, mammals, birds, reptiles, and other taxa, many of which are threatened or endangered. Recently, the region has been mentioned prominently within various listings of crisis ecoregions, endemic bird areas, megadiverse countries, and Global 200 ecoregions (see Brooks et al. 2006). However, the predictive models indicate that about $70-80 \%$ of the original habitat has already been lost and that loss may increase to 80$87 \%$ by 2100 (see Jantz et al. 2015 and Table 5.2). 
Table 5.1 Distribution of total and endemic (in parentheses) species in the four biodiversity hotspots in the $\mathrm{HKH}$

\begin{tabular}{l|l|l|l|l}
\hline Biodiversity & Himalaya & Indo-Burma & $\begin{array}{l}\text { Mountains } \\
\text { of } \\
\text { Southwest } \\
\text { China }\end{array}$ & $\begin{array}{l}\text { Mountains } \\
\text { of Central } \\
\text { Asia }\end{array}$ \\
\hline Plants & $\begin{array}{l}10,000 \\
(3,136)\end{array}$ & $\begin{array}{l}13,500 \\
(7,000)\end{array}$ & $\begin{array}{l}12,000 \\
(3,500)\end{array}$ & $\begin{array}{l}5,500 \\
(1,500)\end{array}$ \\
\hline Mammals & $300(12)$ & $433(73)$ & $237(5)$ & $143(6)$ \\
\hline Birds & $977(15)$ & $1,266(64)$ & $611(2)$ & $489(0)$ \\
\hline Reptiles & $176(48)$ & $522(204)$ & $92(15)$ & $59(1)$ \\
\hline Amphibians & $105(42)$ & $286(154)$ & $90(8)$ & $7(4)$ \\
\hline $\begin{array}{l}\text { Freshwater } \\
\text { fish }\end{array}$ & $269(33)$ & $1,262(553)$ & $92(23)$ & $27(5)$ \\
\hline SOurce Cons) & & & &
\end{tabular}

Source Conservation International (2016)

\subsubsection{Ecosystem Diversity}

The variation in species richness and diversity are mainly driven by ecosystem diversity (Tews et al. 2004). When there is a mosaic of habitats comprised of different ecosystems such as forest, grassland, water bodies, agriculture and so on, species diversity increases due to interspecific facilitation (Cardinale et al. 2002). This is one of the reasons biodiversity is not equally distributed across the HKH; the western part of the region is comparatively homogenous with arid and semi-arid vegetation (Fig. 5.3). A recent analysis identified the dominant terrestrial ecosystems to be high altitude grassland (54\%), followed by forest (20\%), shrubland (15\%), and agricultural land (5\%), with the remaining $6 \%$ composed of barren land, rocky outcrops, built-up areas, snow cover, and water bodies (Xu et al. 2009a).

In socio-ecological systems, people are directly or indirectly dependent on their surrounding ecosystems; forest, rangeland (alpine), agriculture, and wetland ecosystems play an important role in the HKH in this context. The most widespread ecosystem in the HKH is rangeland; it is mostly distributed in the western Himalaya and Tibetan Plateau, and provides habitat for many globally significant plants and animals including one of the highest densities of domesticated animals such as yak (Bos grunniens) (Schaller 1998; Foggin 2012). The forest ecosystem, with about $20 \%$ of the land cover, is one of the most important ecosystems both for local communities and for wildlife living in tropical and temperate conditions. Forest has provided fodder, fuel, medicine, fibre, and many other services for people, and a habitat and corridor for wildlife, for millennia (Uprety et al. 2016; Wang et al. 2016). Although the agriculture ecosystem only covers $5 \%$ of the total area, it is key to the direct provision of food and food security and nutrient supply (Rasul and Sharma 2015). The majority of people are subsistence farmers with comparatively small landholdings compared to their counterparts in lowland areas (Hussain et al. 2016). The region has one of the largest number of high altitude wetlands in the world, around 36 of which are designated as Ramsar sites (Upadhaya et al., 2009). These wetland ecosystems are a repository for a wide range of flora and fauna including threatened and endemic species (Jain et al. 2000; Savillo 2009; Sharma et al. 2016), and many of them are vital to culture and tourism (Maharana et al. 2000; Anand et al. 2012).

The ecosystem diversity is further supported by elevation, micro climate, and aspect variations leading to gradients of forest and other ecosystems along the altitudinal variation (see Fig. 5.4). The gradient from tropical $(<500 \mathrm{~m})$ to alpine ice-snow $(>6000 \mathrm{~m})$, with a principal vertical vegetation regime composed of tropical and subtropical rainforest, temperate broadleaf deciduous or mixed forest, and temperate coniferous forest, including high altitude cold shrub or steppe and cold desert, brings more ecosystem diversity. The variation in ecosystem functions and processes provides different ecosystem services to people and different opportunities to support livelihoods (Miehe et al. 2015b). Some of the ecosystems such as wetlands provide more than $85 \%$ of gross household income locally (Sharma et al. 2015).

Table 5.2 Current and future (seven climate-change scenarios) estimates of loss of area in individual biodiversity hotspots relative to the year 1500

\begin{tabular}{|c|c|c|c|c|c|c|c|c|c|}
\hline \multirow[b]{2}{*}{ Hotspot } & \multicolumn{2}{|c|}{ Current estimates of loss (\%) } & \multicolumn{7}{|c|}{ Year 2100 estimates of $\operatorname{loss}^{\mathrm{a}}(\%)$} \\
\hline & $\begin{array}{l}\text { Mittermeier et al. } \\
(2004)\end{array}$ & $\begin{array}{l}\text { Modelled } \\
2005\end{array}$ & $\mathrm{RCP} 2.6$ & RCP2.6 & RCP4.5 & RCP6.0 & RCP6.0 & RCP8.5 & $\mathrm{RCP} 8.5$ \\
\hline Himalaya & 75 & 77 & 93 & 91 & 91 & 95 & 93 & 86 & 92 \\
\hline Indo-Burma & 95 & 38 & 71 & 64 & 63 & 68 & 64 & 83 & 61 \\
\hline $\begin{array}{l}\text { Mountains of Central } \\
\text { Asia }\end{array}$ & 80 & 69 & 76 & 77 & 77 & 72 & 77 & 77 & 76 \\
\hline $\begin{array}{l}\text { Mountains of } \\
\text { Southwest China }\end{array}$ & 92 & 66 & 97 & 97 & 97 & 83 & 97 & 78 & 96 \\
\hline Total & 86 & 70 & 84 & 78 & 77 & 82 & 80 & 87 & 80 \\
\hline
\end{tabular}

${ }^{\mathrm{a}}$ See Jantz et al. (2015) for descriptions of the land-use change scenarios $\mathrm{RCP}=$ representative concentration pathway 


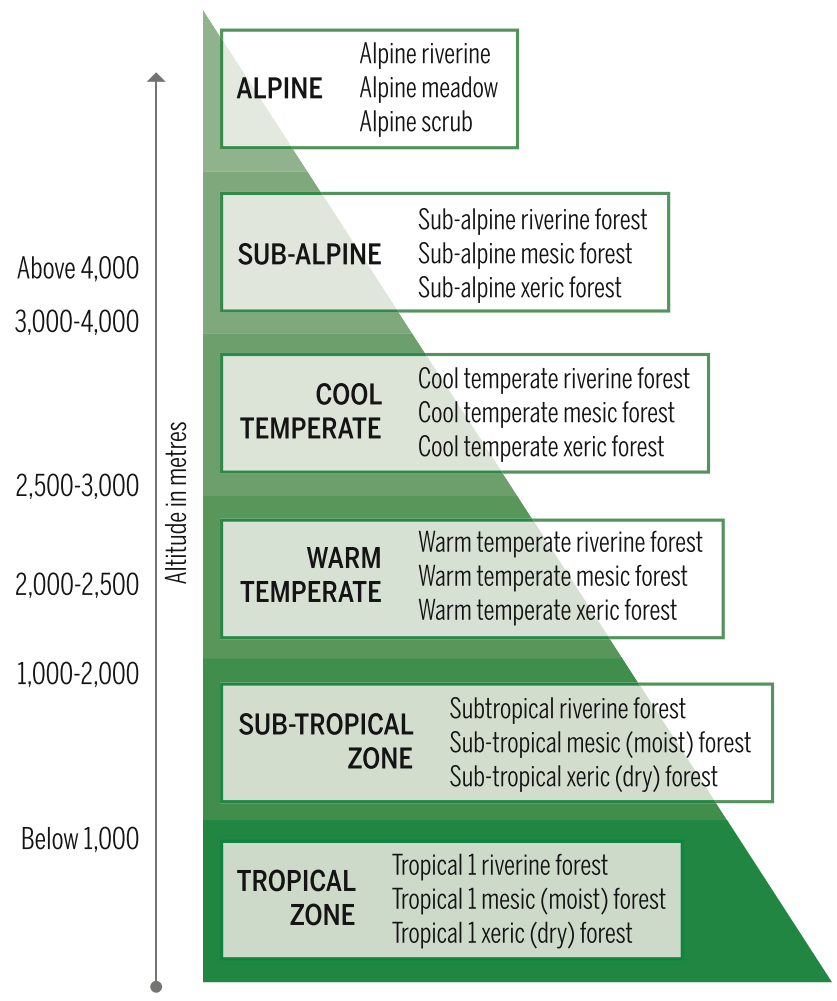

Fig. 5.4 Vegetation zones and dominant forest types found across the HKH (Chettri et al. 2010)

\subsubsection{Species Diversity}

The variation in ecosystems, land use, and landcover across the HKH is reflected in the species distribution, with high diversity and richness in megadiverse countries like China, India, and Myanmar and comparatively less diversity and richness in arid and semi-arid regions such as Afghanistan
(Table 5.3). At least 353 new species were discovered in the Eastern Himalaya between 1998 and 2008, an average of 35 new species finds per year. The discoveries included 242 plants, 16 amphibians, 16 reptiles, 14 fish, 2 birds, 2 mammals, and at least 61 invertebrates (Thompson 2009). In addition, the HKH region - mostly the Eastern Himalayais also known for some iconic species such as Rhododendron. With seven species of Rhododendron have been reported in the western Himalaya, with increasing diversity shown towards the Eastern Himalaya (Nepal, Sikkim and Darjeeling in India, Bhutan, and North East India), and the highest number of species in China (Milleville 2002; Pradhan et al. 2003; Singh 2009; Shu 2005). As many as 46 Rhododendron species have been classified as rare or threatened in the India area of the Eastern Himalaya alone (Menon et al. 2012). In addition, orchids, medicinal and aromatic plants, and wild edible plants also play an important role in livelihoods and local economies and are abundant in the region (Kalita et al. 2014; MoEF 2014). Interestingly, the region also contains, wholly or partially, three of Vavilov's eight centres of origin of cultivated plants (Simpson and Ogorzaly 1986).

\subsubsection{Genetic Diversity}

Genetic diversity, defined as the variety of alleles and genotypes present in a population, is a fundamental source of biodiversity (Hughes et al. 2008). It is critical for the survival and adaptability of a species, helping organisms to cope with current environmental variability, reducing the potentially deleterious effects of close relative breeding, and increasing disease resistance (Frankham 2005). Maintaining diversity at a genetic level also holds significance for species

Table 5.3 Reported species richness in the countries of the HKH

\begin{tabular}{|c|c|c|c|c|c|c|c|c|}
\hline \multirow[t]{2}{*}{ Country } & \multirow{2}{*}{$\begin{array}{l}\text { Area } \\
\left(\mathrm{km}^{2}\right)^{9}\end{array}$} & \multicolumn{2}{|c|}{ Floral diversity } & \multicolumn{5}{|c|}{ Faunal diversity } \\
\hline & & Angiosperms & Gymnosperms & Mammals & Birds & Reptiles & Amphibians & Fish \\
\hline Afghanistan $^{1}$ & 652,230 & $3,500-4,500$ & NA & $137-150$ & $\begin{array}{l}428- \\
515\end{array}$ & $92-112$ & $6-8$ & $101-139$ \\
\hline Bangladesh $^{2}$ & 144,000 & 3,723 & 7 & 128 & 650 & 154 & 49 & 712 \\
\hline Bhutan $^{3}$ & 38,394 & 5,603 & NA & 200 & 700 & 124 & 61 & 91 \\
\hline China $^{4}$ & $9,596,960$ & 34,984 & NA & 556 & 1,300 & 1,186 & 380 & 279 \\
\hline India $^{5}$ & $2,387,590$ & 17,926 & 74 & 423 & 1,233 & 526 & 342 & 3,022 \\
\hline Myanmar $^{6}$ & 676,577 & 11,800 & NA & 251 & 1,000 & 279 & 82 & 350 \\
\hline $\mathrm{Nepal}^{7}$ & 147,181 & 6,973 & 26 & 208 & 867 & 123 & 117 & 230 \\
\hline Pakistan $^{8}$ & 882,000 & 5,757 & 38 & 198 & 696 & 177 & 22 & $\begin{array}{l}>1,000 \text { marine; } 198 \\
\text { freshwater }\end{array}$ \\
\hline
\end{tabular}

Sources ${ }^{1}$ ANBSAP (2013); ${ }^{2} \operatorname{DoE}(2015) ;{ }^{3} \mathrm{MoAF}$ (2014); ${ }^{4} \mathrm{MoEPC}(2014) ;{ }^{5} \mathrm{MoEF}(2004,2008) ;{ }^{6} \mathrm{MoECF}(2011) ;{ }^{7} \mathrm{MoFSC}(2014) ;{ }^{8} \mathrm{CCD}$ (2014); ${ }^{9}$ Chettri and Sharma (2016) (except Nepal)

$\mathrm{NA}=$ data not available

Except for Bhutan and Nepal, the numerical data are for the whole country and not segregated for the HKH region 
evolution, and through agricultural biodiversity contributes to sustaining and strengthening food, nutrition, health, and livelihood security (Notter 1999; Esquinas-Alcázar 2005). The origin of the chicken and its domestication (Gallus gallus domesticus) is thought to be in the region, particularly in India and China (Liu et al. 2006). The huge variety of traditional crops and cultivars used in the subsistence farming system, including swidden agriculture, is very little known outside the region. These species harbour an enormous genetic diversity (landrace/varieties) of both regional and global significance. For example, 2,500 landraces of rice (Oryza sativa) have been identified in Nepal (Gupta et al. 1996). The number could increase significantly if reviewed; the western Himalaya alone adds 100 types of basmati rice (Salgotra et al. 2015). Taro (Colocasia esculenta) is another widely distributed food crop, which is believed to be from the Eastern Himalaya (Xu et al. 2001). Studies have shown that the indigenous crop varieties traditionally cultivated and maintained by farmers contain high levels of genetic diversity and can serve as potential genetic resources for improving yield, resistance to pests and pathogens, and agronomic performance, thereby helping to maintain future food security in the light of the changing climate (Brush 1995; Hoisington et al. 1999; Mandel et al. 2011).

Despite being a repository of genetic resources of the global significance, the region has received comparatively little attention in terms of genetic research and in situ conservation. For example, in a recent review of biodiversity research, Kandel et al. (2016) noted that only around $2 \%$ of the research on the Kangchenjunga Landscape is at genetic level, compared to $20 \%$ at the ecosystem level and $78 \%$ at the species level. The identification and recording of species are still at an early stage, the necessary baseline data for identifying genetic diversity are not available, and the constant monitoring needed to examine population dynamics as a function of changing climate impacts is sorely lacking. The scant amount of genetic-level research could be due to very limited financial resources, lack of institutional capacity, an inadequate knowledge base, lack of accessible sophisticated technologies, and restrictive government policies towards such research in the region (Grajal 1999; Bubela and Gold 2012).

\subsubsection{Functional Diversity}

Functional diversity is a component of biodiversity that generally concerns the range of things that organisms do in communities and ecosystems. A variety of definitions exist, such as "the functional multiplicity within a community" (Tesfaye et al. 2003) and "the value and range of those species and organismal traits that influence ecosystem functioning" (Tilman et al. 2001). But the term is frequently used without definition or reference, normally considering phenotypic trait and/or trophic levels (Tilman et al. 2001). The framework of this paper (see Fig. 5.2) indicates that functional diversity among the individual species within an ecosystem is vitally important for the production and flow of ecosystem services. The physiological interaction among biotic and abiotic elements with a production function is instrumental in the derivation of ecosystem services (see de Groot et al. 2010). Among these, nutrient production from decomposition, water from evapotranspiration, and food from pollination services are important ecosystem functions resulting from functional diversity (see Fig. 5.2). In recent years monitoring the functional values of the ecosystems for monitoring has been recognized for better understanding of the ecosystems (Gagic et al. 2015).

Containing some of the youngest mountain ecosystems on Earth, the HKH ecosystem continues to be shaped and reshaped by anthropogenic and geological processes, leading to diversity. This diversity is manifested by thousands of phenotypic traits and their interaction at different trophic levels supporting species evolution and richness. A very high diversity and wide range of climatic zones are found across this highly heterogeneous region, associated with steep elevational gradients and continental, oceanic, and latitudinal influences. Out of 125 bioclimatic strata identified in the Global Environmental Stratification (GEnS) worldwide, more than 105 are found within the $\mathrm{HKH}$ and its associated downstream basins (Metzger et al. 2013). This wide range of bioclimatic diversity, combined with the heterogeneous terrain and topographic and orographic effects, and along with the confluence of several major floristic zones across the region, has enabled a rich and highly diverse biodiversity to develop, with a high degree of endemism (Fig. 5.4). This diversity is likewise reflected in the many cultures and languages found across and along these mountains.

Functional diversity plays a pivotal role in the provision of ecosystem services, which can also be considered as the benefit from nature for people's wellbeing (Díaz et al. 2015). Functional diversity at ecosystem, species, and genetic levels is fundamental for the lives of the majority of the rural communities living in the HKH. In many parts, $70-80 \%$ of the population live in rural areas, and the majority (60-85\%) are still directly or indirectly dependent on this diversity for their livelihoods (Sharma et al. 2015).

Human colonizers of the Himalaya over past millennia devised a wide range of foraging systems, from nomadism to shifting cultivation, from sedentary agriculture to fishery. The earliest human settlement identified on the Tibetan Plateau was established some 5,200 years before the present (Chen et al. 2015a) (see Fig. 5.5). Ecological and societal feedback shape the flow of services and may promote, reduce, or unravel such bundles during the constant 


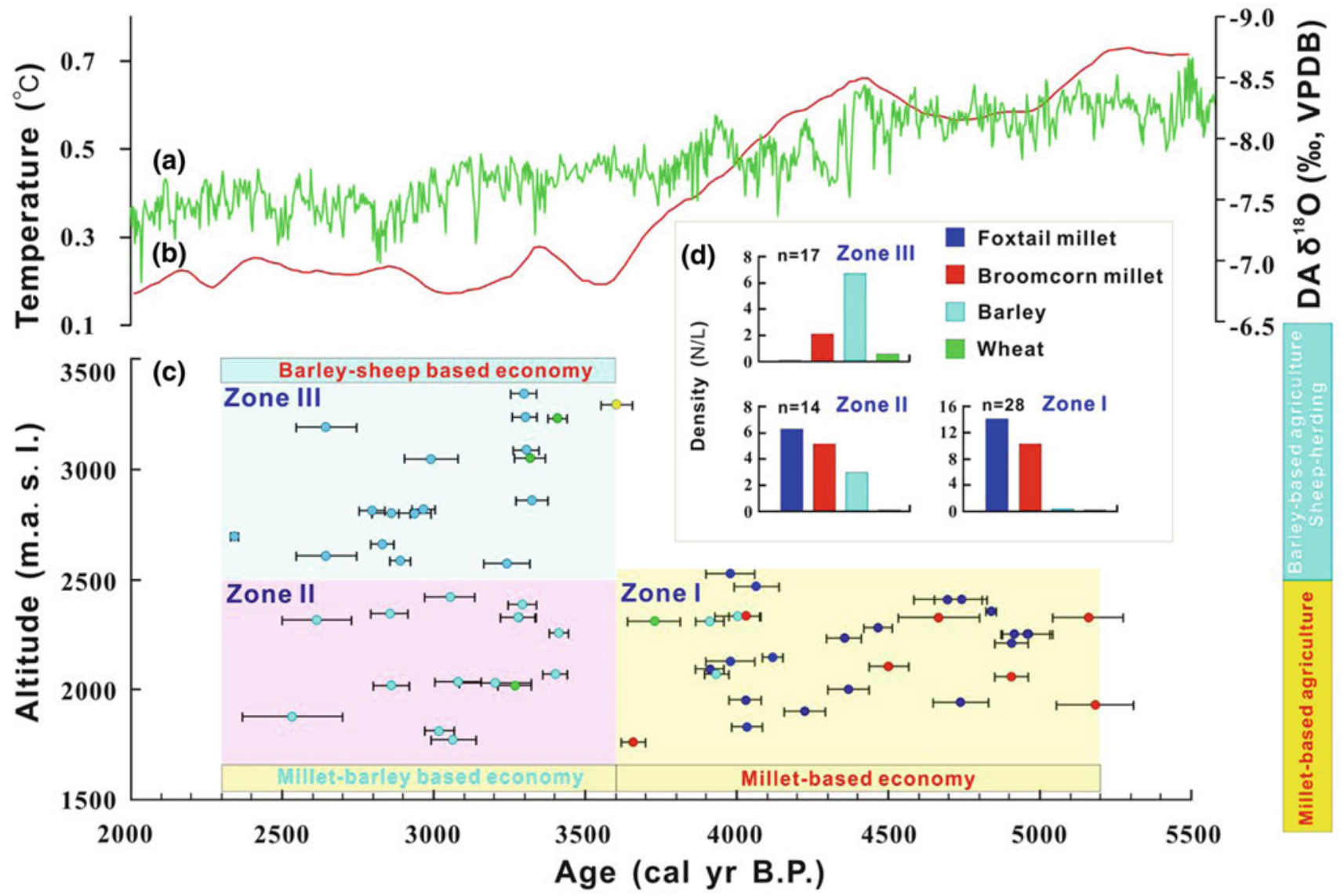

Fig. 5.5 Climatic records, radiocarbon dates, and charred cereal grain records from 53 investigated sites from different archaeological cultures on the northeastern Tibetan Plateau. a Asian summer monsoon changes indicated by Dongge Cave speleothem oxygen isotopes. b Northern Hemisphere $\left(30^{\circ}\right.$ to $\left.90^{\circ} \mathrm{N}\right)$ temperature record compared to $1961-90$ instrumental mean temperature. c Calibrated AMS radiocarbon dates of charred grains (solid symbols with $2 s$ error bar) from the 53 sites at different elevation; Zone I includes 25 sites below 2500 masl dated

negotiation of different trade-offs. In the HKH, cultural diversity is a key contributor to shaping the ecosystems and biodiversity (Turin 2005; Gorenflo et al. 2012). Both ecosystems and cultures have adapted to exist in these relatively remote habitats; for example, the villagers in the Pamir integrated the human body into the seasons and rhythms of their ecological cycle to generate 'calendars of the human body' (Kassam et al. 2011). These coupled socio-ecological systems-facilitating the material, energy, and information flows not only between natural systems and social systems but also among different social systems - may be regarded as cultural landscapes (Taylor and Lennon 2011). In them, a range of cultural beliefs and mores combine taboos, language, technical practices, knowledge transfer, and customary institutions for social consent and governance (Xu et al. 2005). The result may be called traditional ecological knowledge. between 5200 and 3600 calendar years BP; zones II and III include 12 sites below and 17 sites above 2500 masl dated between 3600 and 2300 calendar years BP. Circle colours indicate crops as in (d), with the addition of capers indicated in yellow. d Density variation of crop remains from flotation samples from zones I, II, and III; $\mathrm{N}=$ number of charred grains, $\mathrm{n}=$ number of flotation samples (Reproduced from Chen et al. 2015a)

\subsection{Ecosystem Services-The Source of Human Wellbeing}

The diverse ecosystems of the $\mathrm{HKH}$ are important natural capital and play a critical role in protecting the life-support systems in the HKH and beyond (Maharana et al. 2000; Kubiszewski et al. 2013; Sharma et al. 2015). A large proportion of the population in the region still lives in poverty (Gerlitz et al. 2012) and is highly dependent on ecosystem services for their livelihood and daily requirements (Paudyal et al. 2015; Sharma et al. 2015; Chaudhary et al. 2016a, b). Biodiversity has a great significance for the societal benefits derived from ecosystems, as manifested in a myriad customs, traditions, and sacred values (Zomer and Oli 2011), and as a result, there is an inextricable link in the $\mathrm{HKH}$ between biodiversity, livelihoods, and culture (Aase et al. 
2009; Xu et al. 2009b). Degradation of these values affects the availability and accessibility of ecosystem services for people, which ultimately increases the demand for these resources leading to more pressure on the ecosystems and human society (Badola et al. 2014; Paudyal et al. 2015; Sharma et al. 2015; Chaudhary et al. 2016a, b).

While the importance of protecting mountain ecosystems has been widely accepted (UN 1992), conventional conservation approaches have become a matter of debate and the concept of ecosystem services has risen to prominence (Singh 2002; Naidoo et al. 2008; Chaudhary et al. 2015a, b). Over the past two decades research and publications on ecosystem services have grown exponentially and the concept has been discussed and mainstreamed in many decision-making processes (Chaudhary et al. 2015a, b; Díaz et al. 2015). The idea of ecosystem services dates back to Westman (1977), who suggested that the social value of the benefits that ecosystems provide could potentially be quantifiedso that society can make more informed policy and management decisions (Grêt-Regamey et al. 2012). Many of these ecosystems are long-term premium assets, with benefits that reach far beyond their source (see, for example, Fig. 5.6). They can have multiple functions at different times and scales (Creed et al. 2016). However, one of the challenges that policy makers and managers face while addressing the threats to the ecological integrity of the Himalayas, is the fact that there is still not enough information available about ecological status and human impacts in the region to enable prediction of the losses that will occur as a result of the impacts of natural and human-induced disturbance (Chettri et al. 2010; Thompson and Warburton 1985). Globally, ecosystem values can be broadly categorized into four value systems (Körner 2004):
- Social value: both marketed and non-marketed biodiversity used for social benefits and development

- Cultural value: diverse cultures, species, and landscapes as historical treasures of society

- Ecological value: the interdependence, interaction and co-evaluation of species for maintaining ecological processes and functions

- Economic value: directly generating livelihoods from quality and quantity of desired products as well as providing insurance against failure of crops and livestock.

\subsubsection{Social Value of Ecosystem Services}

Over the past two decades, the ecosystem service conceptthe benefits that humans obtain from ecosystems (MA 2005) - has gained importance among scientists, managers, and policymakers as a way to communicate societal dependence on ecological life-support systems integrating perspectives from both the natural and social sciences (Chaudhary et al. 2015a, b). Although the methodology for ecosystem valuation is still debated, the interdependence of human wellbeing and ecosystem health and biodiversity has now been recognized (Díaz et al. 2015). Biodiversity and the ecosystem services derived from diverse ecosystems have been recognized as important sources since time immemorial of societal development in the HKH (Rai et al. 1994; Awasthi et al. 2003; Chen et al. 2015a). The social value of ecosystem services is critical, as people have relied substantially on these diverse ecosystems for food, shelter, medicine, and so on (Pei 1995; Luck et al. 2009; Joshi and Negi 2011). Transformative change has been possible in many mountain
Fig. 5.6 Forest aquatic ecosystem services affect people long after the time and far from where forest management decisions are made. The vertical axis shows the time lag in terms of multi-decadal recovery and the scale of impacts ranging from local to national and global (Source Creed et al. 2016)

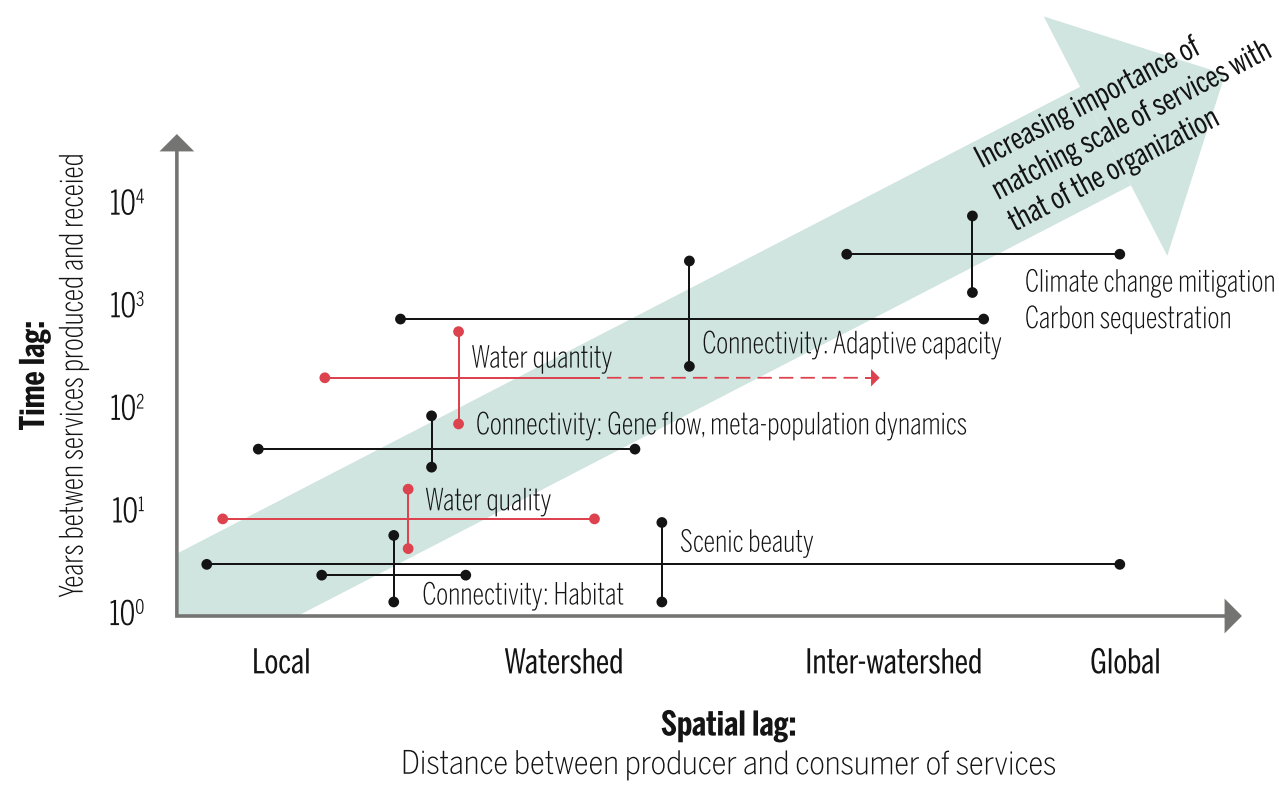


areas based on the dependence on varied ecosystems for subsistence livelihoods. For example, the community living around Koshi Tappu, a Ramsar site in Nepal, indicated 85\% dependency on various ecosystem services (Sharma et al. 2015). Similarly, rangeland and forest ecosystems have provided diverse ecosystem services in most of the rural areas in the HKH (Badola et al. 2010; Dong et al. 2010; Joshi and Negi 2011; Pant et al. 2012). Efforts have been made to understand the complexity of socio-ecological linkages in rangeland (Dong et al. 2010), wetland (Chaudhary et al. 2016a, b), and forest ecosystems (Joshi and Negi 2011). In summary, the ecosystem services derived from the various ecosystems in the HKH have a high value for social development and poverty alleviation.

\subsubsection{Cultural Value of Ecosystem Services}

Cultural services are defined as the "nonmaterial benefits people obtain from ecosystems" and include the "cultural diversity, spiritual and religious values, knowledge systems, educational values, inspiration, aesthetic values, social relations, sense of place, cultural heritage values, recreation and ecotourism" of an ecosystem (MA 2005). These services are often considered subjective, intangible, and difficult to quantify in monetary terms, and thus, are often neglected or completely excluded from valuation (Chan et al. 2012; Daniel et al. 2012). The failure to recognize and integrate cultural services into ecosystem assessment might lead to biased and misleading trade-off assessments, ecosystem management, and landscape planning (Schaich et al. 2010). The cultural linkage of an ecosystem elicits a positive attitude from the local community towards conservation; systems which have associated cultural beliefs are less disrupted and better maintained (Gao et al. 2013). Cultural services are crucial for sustaining the psychological aspects of human wellbeing and contribute significantly to the overall value of a system to societies.

The HKH is home to varied ethnic communities with vast socioeconomic and cultural diversity (Turin 2005). This cultural diversity is associated with the management of the landscape and natural resources, and has been a part of the co-evolution of society and ecosystems with inextricable links between rural livelihoods, land use, human health, and climate change (Wilkes 2008; Xu et al. 2008). Religious beliefs and rituals, traditions, and customs of local communities often have embedded conservation ethics and have influenced the biophysical conditions of an ecosystem. These landscapes include sacred groves and forest streams, holy mountain peaks, traditional agroforestry systems, and sacred lakes. Many such landscapes in the region have been well studied for their biodiversity and tourism value (for example, Maharana et al. 2000; Anthwal et al. 2010), but very few studies have assessed their cultural services (Sharma et al. 2007a, b, c).

\subsubsection{Ecological Value of Ecosystem Services}

The ecological value of the HKH is well appreciated and reported (Chettri et al. 2008; Sharma et al. 2010). Various publications rationalize the ecological value of globally significant species, diversity in ecosystems, and ecosystem functions (Myers et al. 2000; Mittermeier et al. 2004; Brooks et al. 2006). Attempts have also been made to understand the distribution of species (Acharya et al. 2011; Bhardwaj et al. 2012) and ecosystems (Chettri et al. 2012; Zomer et al. 2014). The region's ecological value cannot be overstated considering its species richness and diversity, particularly as the habitat for some of the most fascinating and globally significant species in the world. Moreover, the ecosystem of the HKH includes Mount Everest and is the highest biome in the world, unmatched by any other mountain systems. The value of this diversity has long made the $\mathrm{HKH}$ one of the most favoured destinations for naturalists, geologists, and explorers (Kandel et al. 2016). In recent years, the contribution of forest, rangeland, and wetland ecosystems to carbon sequestration and soil conservation have been widely acknowledged (Upadhyay et al. 2005; Banskota et al. 2007).

\subsubsection{Economic Value of Ecosystem Services}

In recent years, efforts have been made to rationalize the significance of ecosystem services in terms of economic value (Costanza et al. 2016). Although research on ecosystem services has progressed significantly, the proportion of research on actual valuation in economic terms is negligible. This is mainly due to limitations in the methodology and the geographical complexities prevailing in the HKH (Rasul et al. 2011a). However, the growing body of literature clearly states that the economic value of both marketed and non-marketed goods is high for rural communities who depend largely on ecosystem services. One of the most comprehensive assessments is from Bhutan, and although preliminary, is revealing. The total estimated value of ecosystem services was approximately USD 15.5 billion per year, significantly greater than the gross domestic product of USD 3.5 billion per year, while $53 \%$ of the total benefits accrue to people outside Bhutan, and $47 \%$ to those inside (Kubiszewski et al. 2013). The wetland ecosystem is critical for many local communities. For example, some wetlands provide $85 \%$ of the total household income (see Sharma et al. 2015). The forested ecosystem is equally important, contributing $80 \%$ of household income through provisioning services in some places (Pant et al. 2012). 


\subsubsection{Changing Ecosystem Services of the HKH Region}

Meta-analysis considering the available literature review, trend of research on ecosystem services in the HKH was made using search engine such as google scholar. About 400 peer review articles were collected using search word such as 'ecosystem services' and the name of the countries. The results showed, in general, knowledge base and understanding of ecosystem services is increasing (Fig. 5.7). However, despite a wide range of studies on thematic subjects such as hydropower, water, and carbon storage, there are very few qualitative or quantitative assessments of ecosystem services. Although the number of publications has increased as shown by the increasing trend, the overall ratio between numbers of publications reporting decline or an increase in the value of the ecosystem services provided by the HKH has also changed over the last decade. There is also a regional bias in the studies among the countries in the region; most are from India, followed by China, Nepal, Pakistan, Bangladesh, and Bhutan (Fig. 5.8). We did not find any mountain-specific studies from Myanmar, while studies from Afghanistan were limited to reviews. Most of the studies from India have concluded that the ecosystem services provided by the Indian Himalaya have degraded due to rapid developmental activities and population growth. However, studies from China indicate that the flow of ecosystem services has increased after implementation of the Natural Forest Conservation Programme, Sloping Land Conversion Programme, and Grain for Green Programme (Song et al. 2014). This may also be an outcome of the increased number of studies from China over the last decade and innovative programmes.

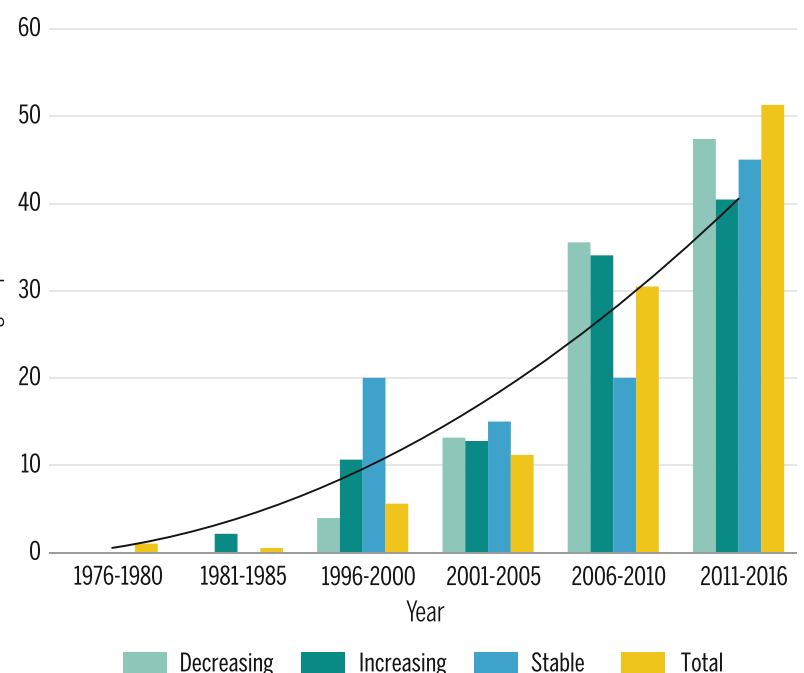

Fig. 5.7 Trend in number of publications on ecosystem services in the $\mathrm{HKH}$, and number of these that predict/suggest/report a decline, increase, or stable state of ES

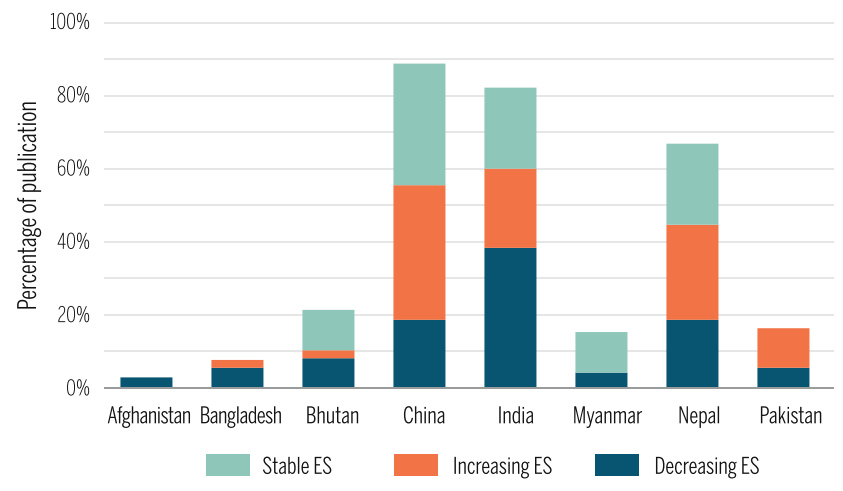

Fig. 5.8 Percentage of publications (1977-2016) and trends predicted in ecosystem services value in the HKH by country

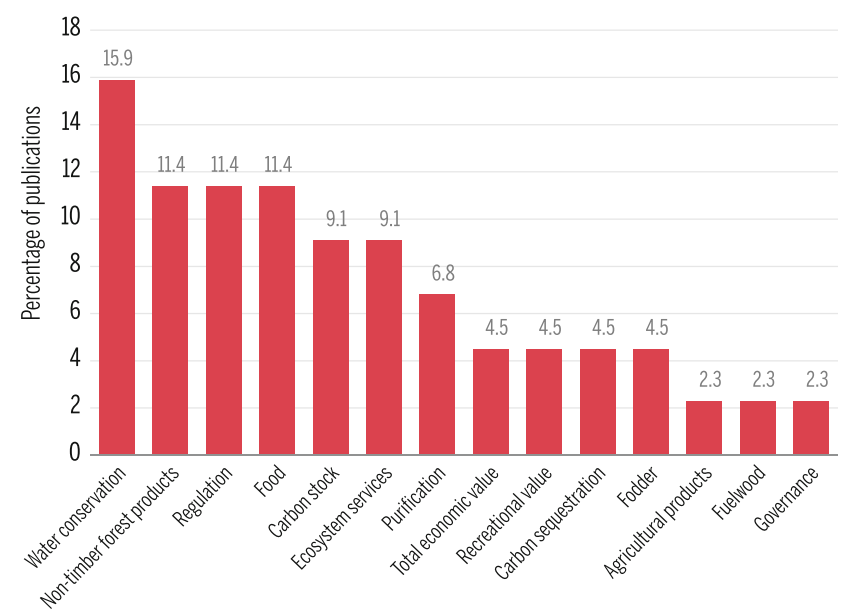

Fig. 5.9 Percentage of publications on different categories of ecosystem services in the $\mathrm{HKH}$

Most of the studies have assessed the benefits people are deriving directly from the natural ecosystems in terms of freshwater, fuelwood, fodder, non-timber forest products (NTFPs), and hydropower. The Himalaya are known as a water tower, contributing immensely to the freshwater needs of the region (Schild 2008; Molden et al. 2014a). Water conservation is the most studied ecosystem service; very few publications have focused on the governance and management of the services in the region (Fig. 5.9).

The overall trend in the provision of ecosystem services increased in recreational value and related activities in the region as most of the areas have become accessible to the visitors. The recreational value is one of the major sources of income for livelihood activities in the area (Nepal 1997; Maharana et al. 2000; Badola et al. 2010). Both NTFPs and water conservation show a stable trend, while biodiversity value and overall ecosystem services show a declining trend (Fig. 5.10). One of the relatively understudied aspects is the role of Himalayan ecosystems in health security (Xu et al. 2008; Sarkar 2011). This is important in view of the climate 


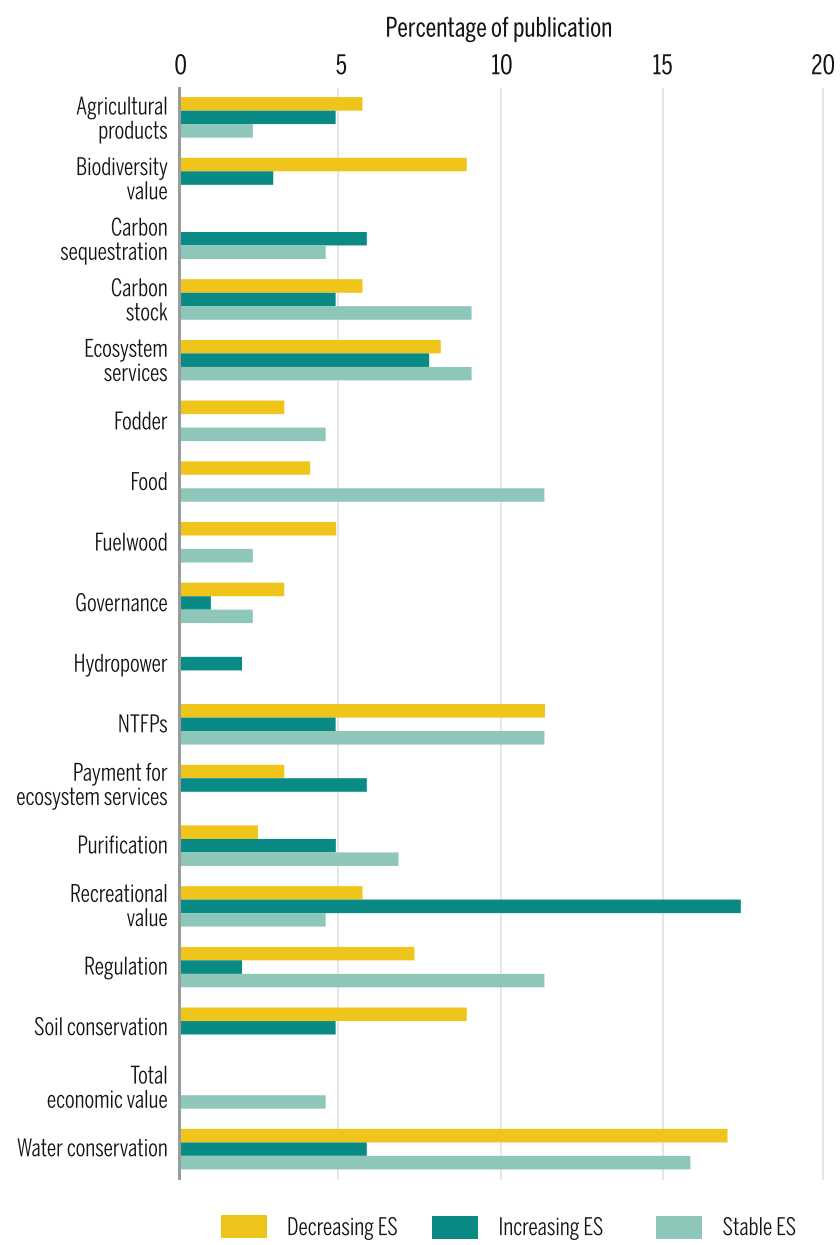

Fig. 5.10 Reported trends within different categories of ecosystem services theme in the $\mathrm{HKH}$ change-induced expansion of vector-borne diseases, as pathogens take advantage of new habitats at elevations that were formerly unsuitable, and diarrheal diseases result from changes in freshwater quality and availability (Ebi et al. 2007; Dangi et al. 2017).

A review of the studies revealed that most focused on a limited topic and lacked a holistic view that would aid better understanding of upstream-downstream linkages; thus they are of limited significance for policy decisions. Large scale studies looking at catchment and basin scales have mainly emerged from the fields of hydrology and geology. An understanding of hydrological dynamics is crucial for sustainable planning and management of water resources in the HKH. However, the lack of hydro-meteorological data in the region, especially for high elevation areas, hinders the process of understanding the system dynamics (Nepal et al. 2014a, b). A huge difference also exists between basins in the extent to which climate change is predicted to affect water availability and food security (Immerzeel et al. 2010). The issue of scale is very important for such assessments. Different issues are relevant at different scales, and the nature of the impacts varies as the scale changes.

The scenarios for the economic values of terrestrial ecosystems services in the HKH countries (Kubiszewski et al. 2016) show a discouraging trend (Table 5.4). The data analysis revealed a $34 \%$ decrease in the value under the Fortress World (FW) scenario compared to the 2011 baseline, and a $28 \%$ decrease in the Market Forces (MF) scenario; Policy Reform (PR) could reduce the trend to $-3 \%$. At the country level, Afghanistan showed the greatest losses in ecosystem services value under both the $\mathrm{FW}$ and $\mathrm{MF}$

Table 5.4 Terrestrial values for the ecosystem services in the HKH countries in 2011 (as base) and percentage change estimated under each of four future scenarios till 2050

\begin{tabular}{|c|c|c|c|c|c|c|c|c|c|c|}
\hline Country & $\begin{array}{l}\text { GDP.PPP } \\
\text { (million } \\
\text { USD) }\end{array}$ & $\begin{array}{l}\text { ESV } \\
\text { (million } \\
\text { USD/yr) }\end{array}$ & $\begin{array}{l}\text { SI-MF } \\
\text { (million } \\
\text { USD/yr) }\end{array}$ & $\begin{array}{l}\text { MF \% } \\
\text { change } \\
\text { from } 2011 \\
(\%)\end{array}$ & $\begin{array}{l}\text { S2-FW } \\
\text { (million } \\
\text { USD/yr) }\end{array}$ & $\begin{array}{l}\text { FW \% } \\
\text { change } \\
\text { from } 2011 \\
(\%)\end{array}$ & $\begin{array}{l}\text { S3-PR } \\
\text { (million } \\
\text { USD/yr) }\end{array}$ & $\begin{array}{l}\text { PR \% } \\
\text { change } \\
\text { from } 2011 \\
(\%)\end{array}$ & $\begin{array}{l}\text { S4-GT } \\
\text { (million } \\
\text { USD/yr) }\end{array}$ & $\begin{array}{l}\text { GT \% } \\
\text { change } \\
\text { from } 2011 \\
(\%)\end{array}$ \\
\hline Afghanistan & 49,338 & 198,662 & 56,919 & -71 & 45,434 & -77 & 178,554 & -10 & 271,418 & 37 \\
\hline Bangladesh & 395,684 & 145,974 & 107,655 & -26 & 69,847 & -52 & 146,427 & 0 & 175,642 & 20 \\
\hline Bhutan & 5,040 & 14,862 & 13,255 & -11 & 11,766 & -21 & 14,936 & 0 & 17,804 & 20 \\
\hline China & $13,810,256$ & $3,586,924$ & $2,596,138$ & -28 & $2,314,370$ & -35 & $3,494,582$ & -3 & $4,524,762$ & 26 \\
\hline India & $5,845,362$ & $1,825,052$ & $1,562,620$ & -14 & $1,357,683$ & -20 & $1,833,906$ & 0 & $2,203,965$ & 21 \\
\hline Myanmar & 51,920 & 369,447 & 305,517 & -17 & 261,775 & -29 & 370,543 & 0 & 443,431 & 20 \\
\hline Nepal & 55,504 & 62,749 & 54,994 & -12 & 48,631 & -22 & 63,655 & 1 & 75,404 & 20 \\
\hline Pakistan & 750,693 & 294,519 & 157,302 & -47 & 137,519 & -53 & 264,412 & -10 & 413,554 & 40 \\
\hline Total & $20,963,797$ & $6,498,189$ & $4,854,400$ & -28 & $4,247,025$ & -39 & $6,367,015$ & -0.3 & $8,125,980$ & 26 \\
\hline
\end{tabular}

Source Kubiszewski et al. (2016)

GDP.PPP = gross domestic product, purchasing power parity; ESV = ecosystem services value; Future scenarios: S1-MF = Market Forces; S2-FW = Fortress World; S3-PR = Policy Reform; S4-GT = Great Transition 
scenarios (77\% and $71 \%$, respectively), followed by Bangladesh and China. Under the PR scenario, Afghanistan and Pakistan showed considerable losses of $10 \%$ in ecosystem services values. However, these two countries also showed the greatest gains under the Great Transitions (GT) scenario with a gain of $40 \%$ in Pakistan and $37 \%$ in Afghanistan. Of the eight countries in the region, Bhutan showed the least loss in ecosystem services value under MF (11\%) and FW (21\%), a $20 \%$ gain under GT, and no change under the PR scenario.

It is undeniable that Himalayan ecosystems provide crucial and valuable ecosystem services to a large part of humanity-more than any other mountain system (GrêtRegamey et al. 2012). But the lack of data in the Himalaya is hindering understanding of the socio-ecological processes. A concerted effort should be made to fill the knowledge gaps through more focused and coordinated collection of relevant data, especially from the high mountain areas. It is important to improve scientific understanding of ecosystem structures and functioning and drivers of change as a basis for formulating comprehensive ecosystem management approaches and strategies that link to human wellbeing and poverty alleviation. Information on the status of human wellbeing and its linkages with the condition of natural resources is required at the scale where a holistic approach can be taken to address the issues. This knowledge would enable informed decision making, especially where trade-offs among conservation, livelihoods, development, and culture are involved, so that an increase in the supply of one service (such as food or fibre) at the expense of others (such as clean water and self-regulation of pests and diseases) is done with some knowledge of spatio-temporal consequences and who would face them.

\subsubsection{Trade-offs and Synergies_-Implications for Development}

The diverse landscapes of the $\mathrm{HKH}$ provide multitudinous services that interrelate in a 'complex dynamic' manner (Birch et al. 2014; Måren et al. 2013; Paudyal et al. 2015). Common drivers affecting multiple ecosystem processes and the interactions among ecosystem services can result in trade-offs and synergies between ecosystem services (Bennett et al. 2009). Trade-offs between ecosystem services arise when one service increases at the cost of another (Ziv et al. 2012), while synergies occur when both services increase or decrease in tandem (Bennett et al. 2009; Haase et al. 2012). Trade-off analysis is a key issue that must be considered when integrating ecosystem services in landscape planning, management, and decision making (de Groot et al. 2010), particularly when analysing alternate pathways leading to sustainable land use in the future (Rounsevell et al. 2012). Any ecosystem management practice that fails to take this into account when attempting to maximise the production of one or more ecosystem services can bring about substantial declines in the provision of other ecosystem services (MA 2005; Bennett et al. 2009). According to the concept of Jointness in Production, there are two different causes for interactions between ES, namely, biological interdependencies and economic interdependencies (Abler 2004; Baumgärtner and Quaas 2010). In landscapes where the provision of ecosystem services is strongly influenced by human activities and vice versa, both these interdependencies are of particular consequence.

The complexity of interactions among ecosystem services is high in managed mountain ecosystem services (GrêtRegamey et al. 2008), where marginally or periodically productive sites may be relatively more sensitive to climate and socioeconomic shifts (Sharma et al. 2009). The heterogeneity of topography and other landscape characteristics in mountain ecosystems makes spatial dynamics more important than temporal, and climate change may influence the elements of the ecosystem differently (Shrestha et al. 2012). Therefore, when managing trade-offs in the provision of mountain ES, the spatial distribution of ES, the trade-off dynamics over time, and their interaction with structural changes in agriculture and forestry must be accounted for (see Box 5.1 and Table 5.5 for examples).

\section{Box 5.1 Trade-offs: hydropower development} and ecosystems in the HKH

Perennial in nature, the Himalayan rivers are regarded as important sources of hydropower generation and have a cumulative hydropower potential that exceeds 500 gigawatts (Pandit et al. 2014). Access to energy for sustenance, agriculture, industries, and other economic activities is critical to the growing population of the HKH region. The large number of rivers that flow out of this region have the potential to fulfil the energy demand and contribute to the wellbeing of the people. There are more than 550 hydropower projects in existence or under construction in the Bhutanese, Indian, Nepalese, and Pakistani Himalayan regions (Pandit et al. 2014). However, it is imperative for hydropower generation in these fragile ecosystems to take into consideration the wide scale impacts that are known to be prevalent while altering these natural resources. For example, most of the dams and hydropower plants located/proposed in the biodiversity rich area of the Indian Himalaya have potential impacts that include forest loss, species extinction, habitat fragmentation, loss of ecosystems, and loss of species diversity (Pandit and Grumbine 2012). Elsewhere, constructing dams on rivers is known to change downstream ecological processes and set in motion complex chain reactions that transform floodplain 
Table 5.5 A few examples of synergies and trade-offs between ES

\begin{tabular}{|c|c|c|c|c|c|c|}
\hline Driver & Service A & Service B & $\begin{array}{l}\text { Shared } \\
\text { driver }\end{array}$ & $\begin{array}{l}\text { Response } \\
\text { type }\end{array}$ & $\begin{array}{l}\text { Interaction } \\
\text { type }\end{array}$ & $\begin{array}{l}\text { Synergy or } \\
\text { trade-off }\end{array}$ \\
\hline $\begin{array}{l}\text { Large-scale afforestation and short } \\
\text { rotation coppice plantations }\end{array}$ & Biodiversity & Biomass production & Yes & Opposite & None & Trade-off \\
\hline $\begin{array}{l}\text { Large-scale afforestation and short } \\
\text { rotation coppice plantations }\end{array}$ & $\begin{array}{l}\text { Biomass } \\
\text { production }\end{array}$ & Soil organic carbon & Yes & Similar & $\begin{array}{l}\text { Unidirectional } \\
\text { (Positive) }\end{array}$ & Synergy \\
\hline $\begin{array}{l}\text { Substitution of extensively used } \\
\text { grassland }\end{array}$ & Food & Biodiversity & Yes & Opposite & None & Trade-off \\
\hline Substitution of farmland with forest & $\begin{array}{l}\text { Carbon } \\
\text { sequestration }\end{array}$ & $\begin{array}{l}\text { Protection from } \\
\text { gravitational hazard }\end{array}$ & Yes & Similar & None & Synergy \\
\hline $\begin{array}{l}\text { Natural forest conversion for exotic } \\
\text { tree plantations }\end{array}$ & Biodiversity & Carbon storage & Yes & Similar & None & Synergy \\
\hline $\begin{array}{l}\text { Natural forest regeneration on } \\
\text { agricultural and grazing land }\end{array}$ & Biodiversity & Carbon storage & Yes & Similar & None & Synergy \\
\hline Agriculture expansion/Fertilizer use & $\begin{array}{l}\text { Agricultural } \\
\text { production }\end{array}$ & Water quality & Yes & Opposite & None & Trade-off \\
\hline $\begin{array}{l}\text { Maintaining forest patches close to } \\
\text { coffee plantations }\end{array}$ & Pollination & $\begin{array}{l}\text { Agricultural } \\
\text { production }\end{array}$ & No & NA & $\begin{array}{l}\text { Unidirectional } \\
\text { (Positive) }\end{array}$ & Synergy \\
\hline Trail building & $\begin{array}{l}\text { Cultural } \\
\text { tourism }\end{array}$ & $\begin{array}{l}\text { Agricultural } \\
\text { production }\end{array}$ & No & NA & None & None \\
\hline Afforestation & $\begin{array}{l}\text { Carbon } \\
\text { sequestration }\end{array}$ & Water quantity & Yes & Opposite & $\begin{array}{l}\text { Unidirectional } \\
\text { (Negative) }\end{array}$ & Trade-off \\
\hline
\end{tabular}

Source Bennett et al. (2009)

$\mathrm{NA}=$ data not available

vegetation dynamics (Wieringa and Morton 1996). With impacts ranging from changes in river geomorphology and hydrology (Brandt 2000) to impairment of the ecological integrity of rivers through the extirpation of species and loss of ecosystem services (Richter et al. 2003), river regulation is the most substantial and widespread anthropogenic effect on riverine ecosystems (Pandit and Grumbine 2012).

\subsection{Conservation and Management Practices}

In recent decades, the $\mathrm{HKH}$ has witnessed significant conceptual development in biodiversity conservation, from 'people exclusionary' and 'species-focused' to 'people-centred community-based' approaches. The United Nations Conference on Environment and Development (UNCED) in 1992 placed a premium on people's participation and promotion of this conceptual shift in both natural resources management and biodiversity conservation (UN 1992). In response, participatory approaches evolved as the accepted means in various sectors in the HKH (Sharma et al. 2010). The classical approach of biodiversity conservation, which started with an emphasis on the conservation of flagship species (Yonzon 1989; Wikramanayake et al. 1998), evolved to landscape level conservation, with the understanding that 'conservation and management of biodiversity are impossible without people's participation' (Chettri et al. 2010; Zomer and Oli 2011; Bajracharya et al. 2015). Since the 1980s, de-centralization and devolution of authority for biodiversity conservation have been evident in governments' efforts across the HKH (Desai et al. 2011; Sharma et al. 2010; Sunam et al. 2015). During the process, it was realised that biodiversity management by local people is more effective when the utility value and benefit to communities is evident (see Gurung and Seeland 2008). After the late 1990s, conservation approaches in the HKH took on a new dimension with the concept of linking the existing protected areas with biological corridors (Sherpa and Norbu 1999). This approach, while addressing the biophysical advantages of corridors for migration and habitat contiguity, also supports species refugia for restoration, and shifting of species and habitat types in response to environmental pressures such as climate change. Subsequently, the concept of landscape-level conservation approaches evolved in the region, generally adopting the ecosystem approach advocated by the Convention on Biological Diversity (CBD) (see Sharma et al. 2010). These evolutions comprised both ex situ and in situ approaches. In addition, inclusion of traditional ecological knowledge, belief, and culture also contributed substantially in addressing the conservation goal. 


\subsubsection{Flagship and Keystone Species Conservation}

As a result of its ecosystem diversity, the HKH is one of the most biodiverse areas in the world with the highest number of species and endemism (Myers et al. 2000; Mittermeier et al. 2004). Large mammal in situ conservation has a long history. It has been practised since 1950 with species like the greater one-horned rhinoceros (Rhinoceros unicornis), Asian elephant (Elephas maximus), and Bengal tiger (Panthera tigris tigris) in the tropical lowlands, red panda (Ailurus fulgens) and Asian black bear (Ursus tibetanus) in the temperate region, and snow leopard (Panthera uncia) and Himalayan musk deer (Moschus leucogaster) in the alpine region. The status of many of these species is facing additional challenges (see Table 5.6). Despite tireless efforts towards conservation, the majority of species are being driven towards extinction. The exceptions are Tibetan antelope or chiru (Pantholops hodgsonii) and the giant panda (Ailuropoda melanoleuca), which were removed from the endangered species list by the International Union for Conservation of Nature (IUCN) in 2016.

Some of the iconic species in the HKH have been researched more than others (Kandel et al. 2016). Understanding of the ecology of the greater one-horned rhinoceros has considerably improved (Dinerstein and Price 1991; Pradhan et al. 2008); the population is either stable or has increased in its present range countries (Thapa et al. 2013). However, the historical range that extended along the floodplains of the Ganges, Brahmaputra, and Sindh Rivers from Pakistan to the Indo-Burma border (Amin et al. 2006) is now restricted to nine populations in protected areas (PAs) in India and Nepal (Menon 1966). With the exception of the populations in Chitwan National Park in Nepal and Kaziranga National Park and Jaldapara Wildlife Sanctuary in India, the populations each number less than 150 individuals. Notably, Nepal has made significant progress in reversing the decreasing trend of rhinoceros (Fig. 5.11) and has also celebrated three consecutive years of zero poaching (Acharya 2015). Likewise, periodic status reports from the snow leopard home range countries have added to the limited knowledge about this elusive species (Karmacharya et al. 2011; Ale et al. 2014; Alexander et al. 2016). New dimension of species range with sub-species was recently added for now leopard (Janecka et al. 2017). However, analysis of the impact of climate change on the range of snow leopards predicts a contraction in suitable habitat and a fragmentation of distribution - both of which could cause a significant contraction in the range of the species (Forrest et al. 2012; Li et al. 2016). Red panda is another flagship species in the temperate forest, confined to three global biodiversity hotspots-Himalaya, Indo-Burma, and the mountains of southwest China (Kandel et al. 2015).
Although it is one of the most researched species in the Eastern Himalaya (Kandel et al. 2016), very little is known about its ecology and distribution (Yonzon 1989; Wei et al. 1999; Choudhary 2001; Pradhan et al. 2001; Groves 2011; Dorji et al. 2012). Red panda has been sighted in five of the eight HKH countries (Bhutan, China, India, Nepal, and Myanmar), and has an estimated habitat area $32,600 \mathrm{~km}^{2}$ within the region (Kandel et al. 2015). However, unlike snow leopard, tiger, and rhinoceros, the red panda has yet to receive global attention for conservation.

\subsubsection{Protected Areas Management}

The HKH has made significant progress in the establishment of PAs in recent decades (Chettri et al. 2008). As of 2007 , there were 488 PAs (IUCN category I-VI) within the HKH, covering more than 1.6 million $\mathrm{km}^{2}$ or about $39 \%$ of the region's terrestrial area (Table 5.7), with significant growth witnessed over the last three decades (Fig. 5.12). Although PA coverage has been identified as a key indicator for assessing progress in reaching the Aichi targets (Secretariat of CBD 2014), many scholars have pointed out that the percentage of area protected in a given country or biome is not a strong indicator of actual conservation needs or effective action (Oli et al. 2013). In particular, this indicator overlooks the fact that biodiversity is unevenly distributed across the region. For example, the Brahmaputra Basin in the Eastern Himalaya is significant for both aquatic and terrestrial biodiversity with a high level of endemic species and high proportion of rare, endangered, and threatened species compared to the western Himalaya (see Allen et al. 2010). More significant, perhaps, is the fact that actual implementation of conservation measures within PAs varies greatly across the region. In Myanmar, for example, human-induced pressure and lack of financial and skilled human resources are impinging on the effective management of PAs (Rao et al. 2002). Bawa (2006) also points out that local challenges, such as a lack of economic opportunities, interdisciplinarity in conservation actions, institutional development, skilled human resources, and large-scale conservation approaches hinder conservation. In spite of these challenges, half of the HKH countries - Bhutan, China, Nepal, and Pakistan - have either reached, crossed, or are heading towards the global target of $17 \%$ area covered by PAs by 2020 (see Table 5.7).

\subsubsection{Conservation Through Traditional Knowledge}

Management of resources to sustain the flow of ecosystem services was, and still is, widely practised by many communities in the Himalaya as part of their traditional 


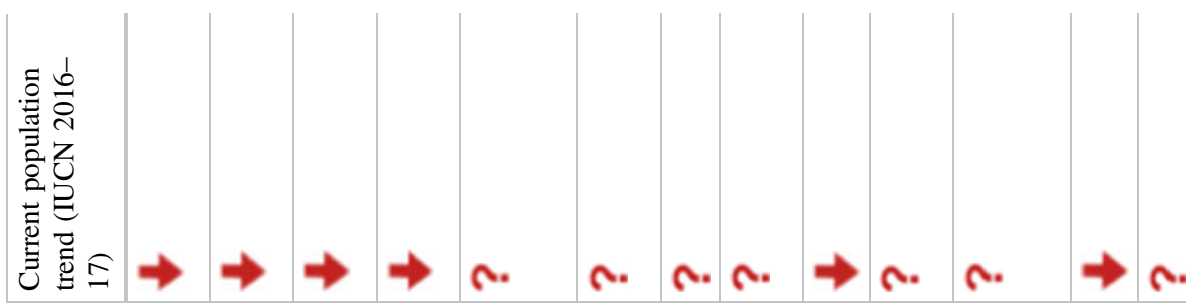

空

㞯导导至 z

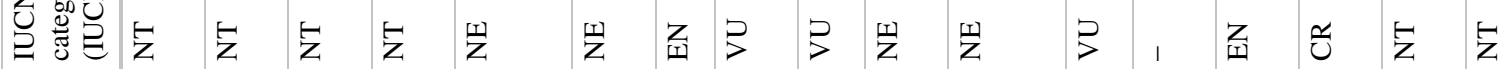

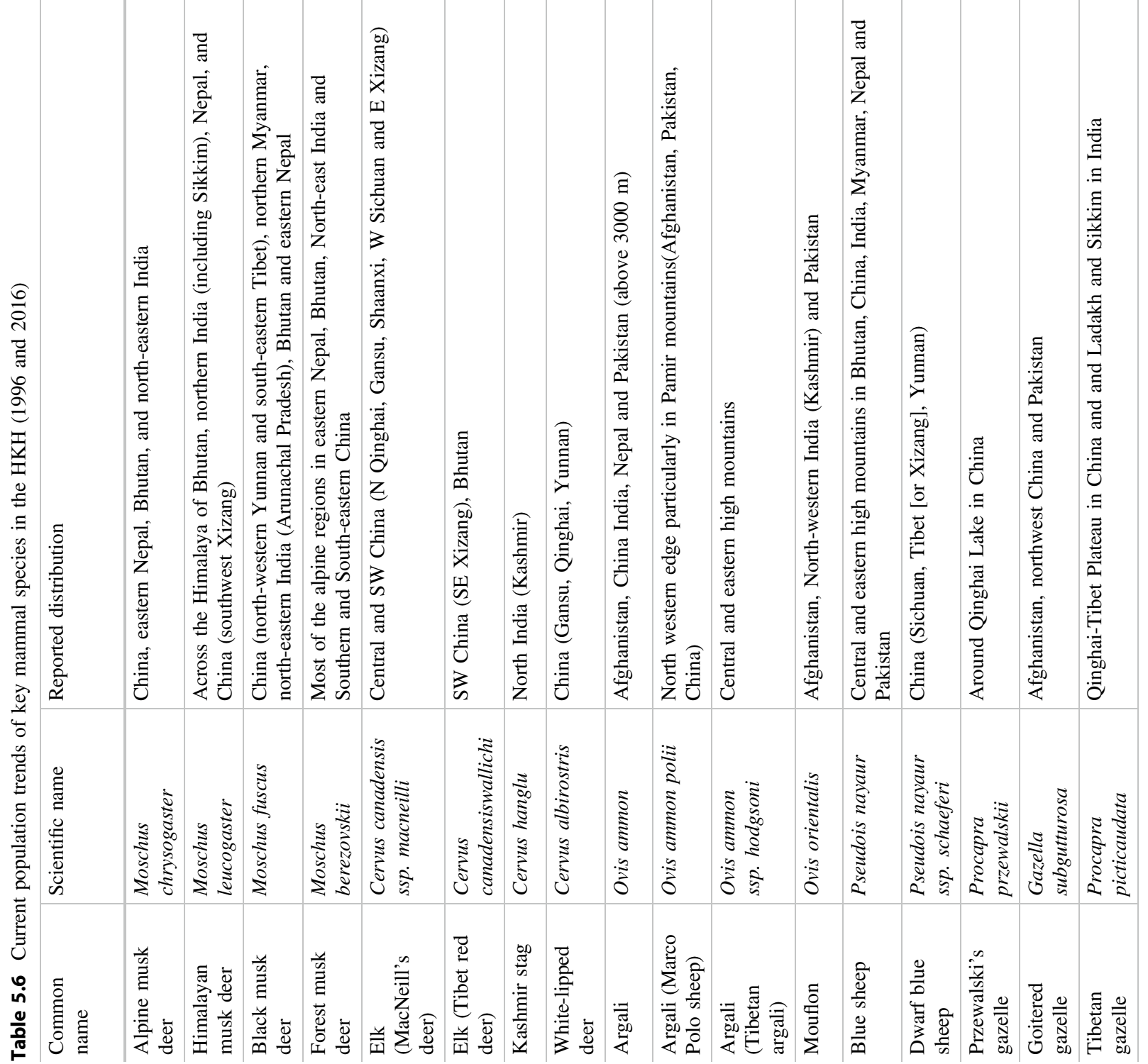




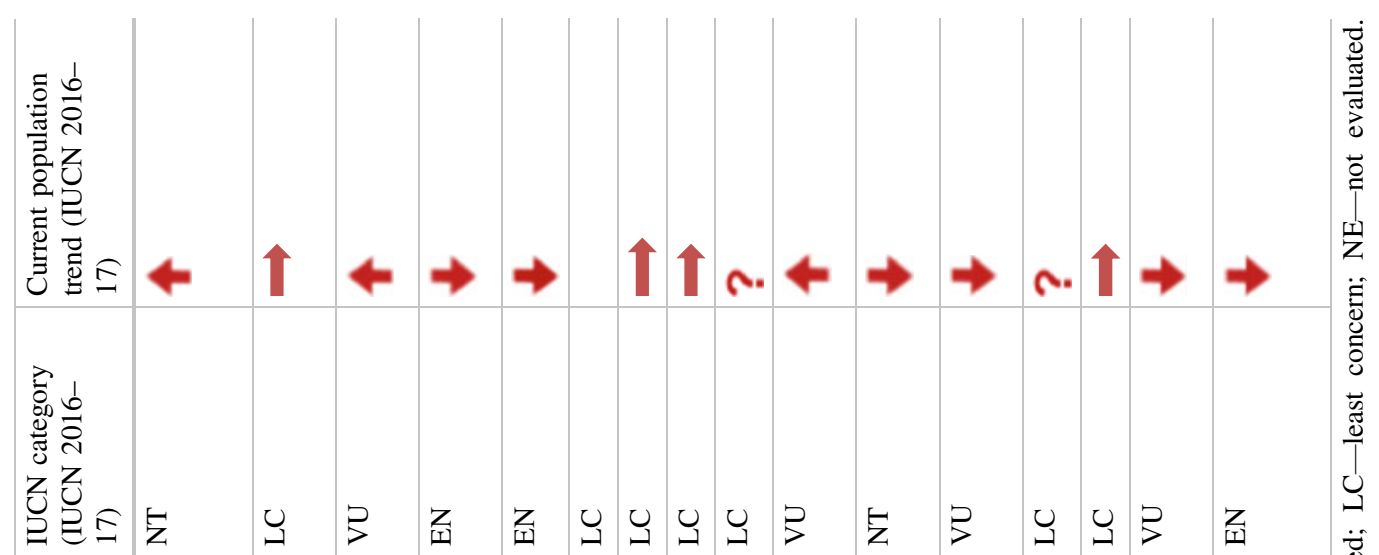

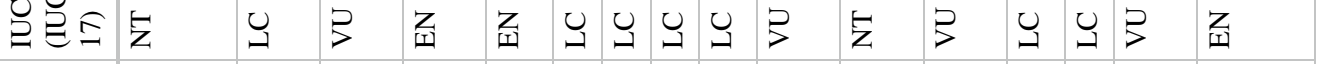

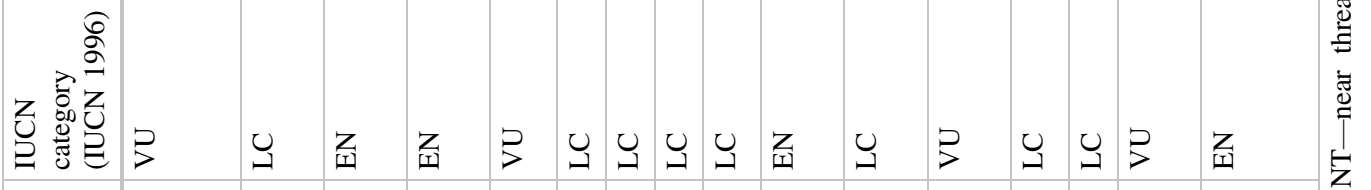

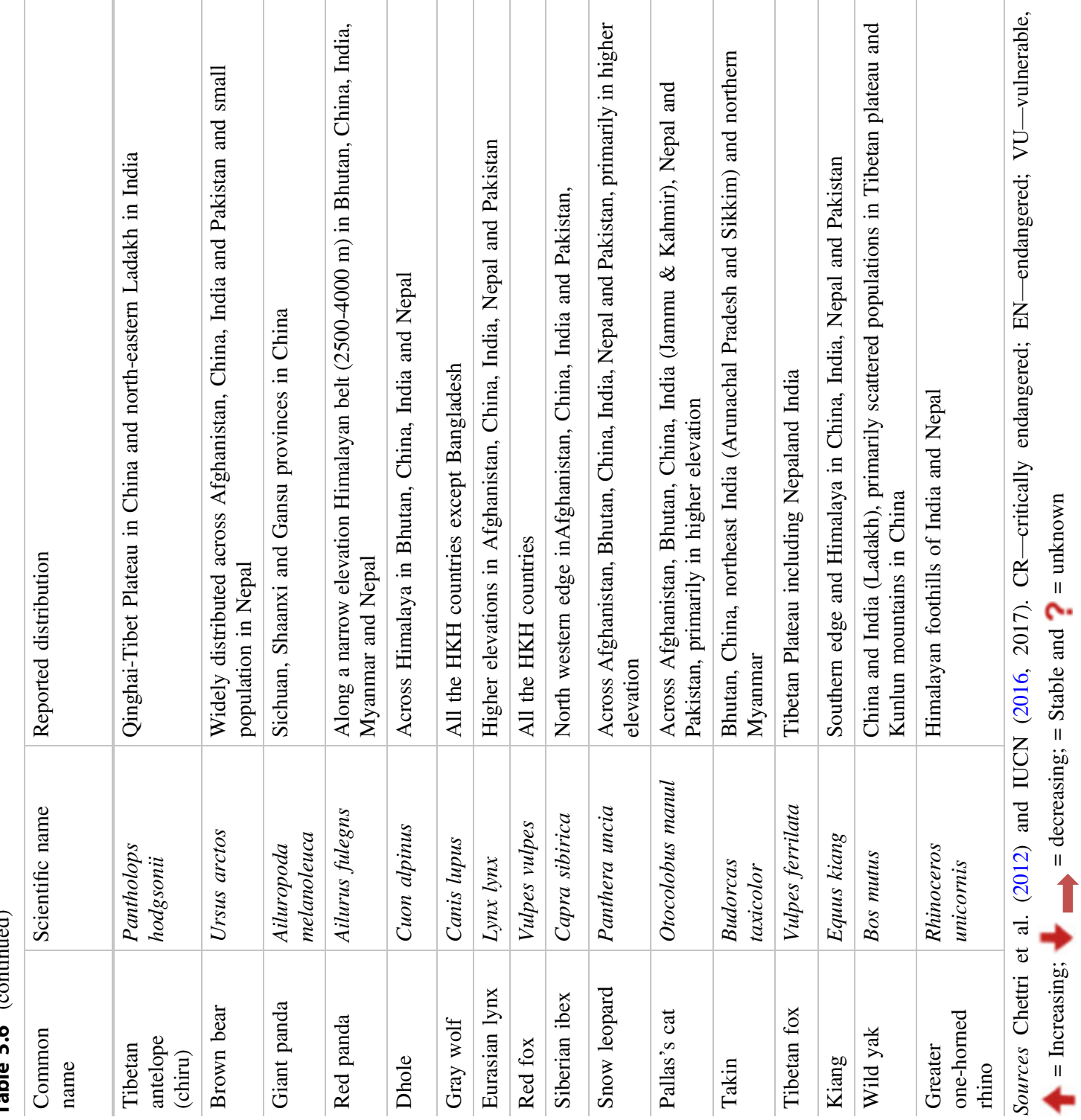




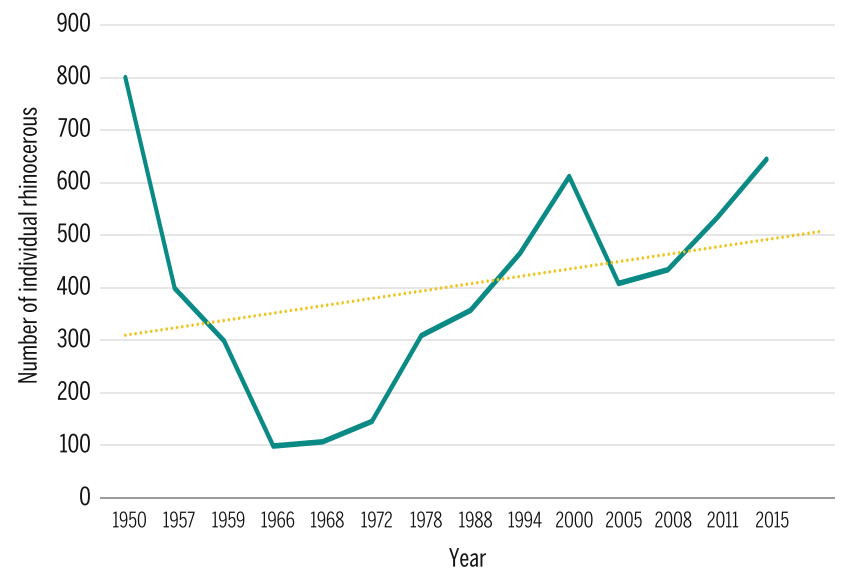

Fig. 5.11 Population of the greater one-horned rhinoceros in Nepal from 1950 to 2015 (Source Acharya 2015)

Table 5.7 Number and area of PAs in the HKH (as of 2007)

\begin{tabular}{l|l|l|l|l}
\hline Country & $\begin{array}{l}\text { Number } \\
\text { of PAs }\end{array}$ & $\begin{array}{l}\text { PA } \\
\text { coverage } \\
\left(\mathrm{km}^{2}\right)\end{array}$ & $\begin{array}{l}\text { \% of PA } \\
\text { coverage } \\
\text { with respect } \\
\text { to country }\end{array}$ & $\begin{array}{l}\text { \% of PA } \\
\text { coverage with } \\
\text { respect to total } \\
\text { area of HKH }\end{array}$ \\
\hline Afghanistan & 6 & 2,461 & 0.44 & 0.06 \\
\hline Bangladesh & 5 & 632 & 1.70 & 0.01 \\
\hline Bhutan & 10 & 16,396 & 42.71 & 0.38 \\
\hline China & 221 & $1,522,172$ & 15.15 & 35.50 \\
\hline India & 135 & 62,417 & 8.99 & 1.46 \\
\hline Myanmar & 16 & 23,967 & 5.32 & 0.56 \\
\hline Nepal & 20 & 34,357 & 23.34 & 0.80 \\
\hline Pakistan & 76 & 18,721 & 11.85 & 0.44 \\
\hline Total & 489 & $1,681,123$ & NA & 39.21 \\
\hline SOurces Sharm & & & &
\end{tabular}

Sources Sharma et al. (2010); ${ }^{\mathrm{a}} \mathrm{CBS}$ (2014)

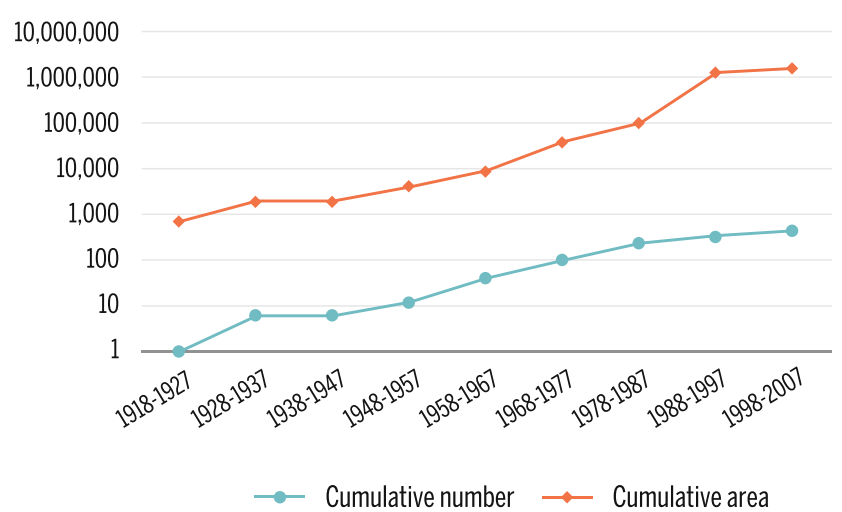

Fig. 5.12 Trend (log value) in number and coverage of protected areas in the HKH from 1918 to 2007 (Chettri et al. 2008)

ecological knowledge system (Dudley et al. 2009; Singh et al. 2011). The blending of cultural, religious, and traditional knowledge systems has contributed substantially to the overall goal of conservation of species, ecosystems, and genetic diversity (Salick et al. 2007; Anthwal et al. 2010). There are numerous plants, animals, and ecosystems (forests, ponds, rivers, mountain peaks) across the region which have been conserved effectively through traditional practices. For example, there are numerous examples in the Himalayas of conservation of sacred groves maintaining significantly higher diversity compared to other areas (Khumbongmayum et al. 2005; Arora 2006). Traditional conservation practices are also regulated by customary laws through participatory decision-making processes. This is evident, for example, in the grazing and other resource management practices regulated through Dzumsa in North Sikkim (Acharya and Sharma 2012), and in the northern part of Humla District, Nepal, in the Kailash Sacred Landscape (Zomer and Oli 2011; Basnet and Chaudhary 2017). Such practices focus on management of ecosystems (Anderson et al. 2005), species (Mehra et al. 2014), or resource use patterns (Acharya and Sharma 2012). Many of these practices are categorised as community-conserved areas (CCA) or key biodiversity areas (KBA) and are being mainstreamed in national conservation practices. These CCAs and KBAs are increasing the focus of conservation interventions outside formal PA systems.

Religious and cultural beliefs related to natural resources have also played an important role in the conservation of the resources in the Himalaya, with the use and exploitation of certain plant and animal species prohibited in many areas (Negi 2005). For example, some of the forests in Garhwal and Kumaon in Uttarakhand, such as the Hariyali Sacred Landscape and Haat Kali Sacred Grove, cannot be used by anyone because they are dedicated to a deity and the forests and streams originating from them are considered sacred (Negi 2005; Sinha and Mishra 2015). In Chhyangru village in Byas Village Development Committee in the Api Nampa Conservation Area, Nepal, people decided to establish a temple in the forest called 'Shyanchho' to prevent further deforestation and degradation and conserve the forest as sacred forest (Chaudhary et al. 2017). Buddhist beliefs have been influential in conserving natural landscapes as ecocultural landscapes, including high elevation lakes and their basins in Ladakh and Sikkim (Maharana et al. 2000; Chandola 2012). In China, there are a few examples where cultural diversity manifested in social and cultural values of natural resources has played an important role in conservation (Anderson et al. 2005; Brandt et al. 2013a). Similarly, the Apatani ecocultural landscape in Arunachal Pradesh is protected by a mix of social and religious institutions which make use of traditional ecological knowledge in sustainable resource management. Hence, there is a growing recognition of a form of environmental governance that acknowledges the role of local communities and their traditional practices to restrain unrelenting forest degeneration while ensuring ecological and economic benefits for the community (Paul and Chakrabarti 2011; MoAF 2014). 
Table 5.8 Landscape initiatives in the HKH

\begin{tabular}{|c|c|c|c|}
\hline Landscape initiative & Geographical coverage & Main themes & Source \\
\hline $\begin{array}{l}\text { Bhutan biological } \\
\text { conservation } \\
\text { complex }\end{array}$ & Bhutan & Protected areas and conservation corridors & $\begin{array}{l}\text { Sherpa and } \\
\text { Norbu (1999), } \\
\text { NCD (2004) }\end{array}$ \\
\hline Everest complex & China and Nepal & $\begin{array}{l}\text { Regional cooperation, information sharing, and } \\
\text { developing decision-making tools }\end{array}$ & $\begin{array}{l}\text { Sherpa et al. } \\
\text { (2003), } \\
\text { Bajracharya } \\
\text { et al. (2010) }\end{array}$ \\
\hline Terai arc landscape & Nepal and India & $\begin{array}{l}\text { Community-based conservation in protected areas } \\
\text { and conservation corridors }\end{array}$ & $\begin{array}{l}\text { Gurung } \\
(2004 \mathrm{~b}) \\
\text { MoFSC } \\
(2015 \mathrm{a})\end{array}$ \\
\hline $\begin{array}{l}\text { Kangchenjunga } \\
\text { landscape }\end{array}$ & $\begin{array}{l}\text { Eastern Nepal, Sikkim and north Bengal in } \\
\text { India, and western Bhutan }\end{array}$ & $\begin{array}{l}\text { Conservation and development in protected areas } \\
\text { and conservation corridors }\end{array}$ & $\begin{array}{l}\text { Sharma and } \\
\text { Chettri (2005) }\end{array}$ \\
\hline $\begin{array}{l}\text { Kailash sacred } \\
\text { landscape }\end{array}$ & $\begin{array}{l}\text { Western Nepal, Uttarakhand in India, and } \\
\text { Tibet autonomous region in China }\end{array}$ & $\begin{array}{l}\text { Conservation and development around sacred sites } \\
\text { and in protected areas }\end{array}$ & $\begin{array}{l}\text { Zomer and Oli } \\
(2011)\end{array}$ \\
\hline $\begin{array}{l}\text { Far-Eastern } \\
\text { himalaya }\end{array}$ & $\begin{array}{l}\text { Arunachal Pradesh in India, Kachin State } \\
\text { in Myanmar, and Yunnan in China }\end{array}$ & $\begin{array}{l}\text { Conservation and development in biodiversity } \\
\text { hotspots }\end{array}$ & $\begin{array}{l}\text { Guangwei } \\
(2002), \text { Shakya } \\
\text { et al. (2011) }\end{array}$ \\
\hline Karakoram pamir & $\begin{array}{l}\text { Afghanistan, China, Pakistan, and } \\
\text { Tajikistan }\end{array}$ & Conservation and development in arid ecosystems & $\begin{array}{l}\text { Ning et al. } \\
(2014)\end{array}$ \\
\hline $\begin{array}{l}\text { Chitwan-Annapurna } \\
\text { landscape }\end{array}$ & $\begin{array}{l}\text { Nepal from Chitwan national park in the } \\
\text { south to Manaslu, Langtang, and } \\
\text { Annapurna in the north covering } 19 \\
\text { districts }\end{array}$ & $\begin{array}{l}\text { Conservation and development in the Gandaki } \\
\text { river basin from tropical lowland Terai to alpine } \\
\text { high mountain and cold and dry trans-Himalaya }\end{array}$ & $\begin{array}{l}\text { MoFSC } \\
(2015 b)\end{array}$ \\
\hline $\begin{array}{l}\text { Sacred himalayan } \\
\text { landscape, Nepal }\end{array}$ & $\begin{array}{l}\text { Koshi basin covering Langtang national } \\
\text { park to Makalu Barun national park }\end{array}$ & $\begin{array}{l}\text { Protected area management, river basin } \\
\text { management, community forest and cultural } \\
\text { conservation }\end{array}$ & MoFSC (2016) \\
\hline $\begin{array}{l}\text { Western mountain } \\
\text { landscape }\end{array}$ & $\begin{array}{l}\text { Fourteen mountain districts in the } \\
\text { Mid-western and Far-western development } \\
\text { regions in Nepal }\end{array}$ & $\begin{array}{l}\text { Chure, mid-mountains, high-mountains, protected } \\
\text { area management, community forest, protection } \\
\text { forest, Karnali, Bheri and Seti river basin }\end{array}$ & MoFSC (2017) \\
\hline
\end{tabular}

Adapted and modified from Chettri and Sharma (2016)

\subsubsection{The Landscape Approach-Recognizing Complexity and Understanding Linkages}

Landscape-level biodiversity conservation is an evolving concept in the HKH. The concept has emerged primarily out of recognition that strict protection through a network of PAs (national parks, sanctuaries, wildlife reserves, and others) is an essential but insufficient strategy for biodiversity conservation (Wikramanayake et al. 2004). Now, the focus has shifted from preserving isolated patches of sustained wilderness in the form of PAs to maintaining landscape integrity (Chettri et al. 2008; Wikramanayake et al. 2011) and seeing - and conservingecosystems as part of larger agro-ecological and sociocultural landscape (Zomer and Oli 2011). These efforts, including protection through policy and practices, have resulted in an increase in population of many wildlife species (Acharya 2015). The transboundary landscape approach is also gaining prominence in many areas in the search for solutions to reconcile conservation and development trade-offs (see Sharma et al. 2007b; Zomer and Oli 2011). In addition, the approach is addressing the need for regional cooperation, knowledge and information sharing, and opportunities for cross-learning and capacity building from best practices. There are a number of landscape-level initiatives for biodiversity conservation in the HKH at different development levels (Table 5.8). The majority of these initiatives have looked at ways of reconciling conservation with development with a focus on community wellbeing. However, differences in conservation policies and practices have led to differences in reaching conservation goals (see Box 5.2). 


\section{Box 5.2 Results of diverse policies and practices}

The Kangchenjunga Landscape, a transboundary complex shared by Bhutan, India, and Nepal, has 19 protected areas (see ICIMOD, WCD, GBPNIHESD, RECAST 2017), 17 in India and one each in Bhutan and Nepal. Nine are transboundary in nature, with differences in their protected category on different sides of the border. They include the Kangchenjunga Conservation Area in Nepal which is contiguous with the Khangchendzonga National Park and Biosphere Reserve in India; the Buxa Tiger Reserve in India which is connected to unreserved areas in Bhutan; the Jigme Khesar Strict Nature Reserve in Bhutan which is connected to Neora Valley National Park and Pangolakha Wildlife Sanctuary in India; and the Singhalila National Park in India which is contiguous with unreserved areas in eastern Nepal. These variations in protected area management systems have led to variations in effectiveness in terms of performance and reaching conservation goals (Oli et al. 2013).

\subsubsection{Participatory Forest Resources Management Practices}

The rapid depletion and degradation of forest resources in the last few decades has resulted in a serious threat to rural livelihoods and environmental sustainability in the HKH. Increasing awareness of the critical situation amongst all actors has led governments to endorse a set of new forest policies and legal frameworks over the last 15-20 years that have enabled forest management practices to flourish. Different types of management system have been introduced - community forestry (CF) and leasehold forestry (LHF) in Nepal, joint forest management (JFM) in India, community-based natural resources management (CBNRM) and an integrated conservation and development programme (ICDP) in Bhutan, and others - but in all the main objective was to address the issue of degrading forest resources through decentralized governance systems. Bangladesh, Bhutan, India, and Nepal, in particular, have shifted their forestry policies from highly centralized approaches to a participatory type of forest management.

Participatory forest management (PFM) began in Bangladesh in the early 1980 s under the banner of social forestry (SF). By 2005 , more than 40,000 ha of forestland were under SF, which has now become an integral part of the country's forest management (Chowdhury and Koike 2010). In Bhutan, CBNRM, which includes SF and CF, was initiated in the early 1980s. The Ninth Five Year Plan (20022007) emphasized PFM as a primary driver of forest management; the number of community forest management groups increased from 31 in 2006 to 677 in 2016, benefiting 28,311 households (Rasul et al. 2011b; MoAF 2016). JFM in India brought an important breakthrough in the relationship between the Forest Department and the community, and is now the primary driver of forest management in India, spreading over 28 states and covering 21.44 million ha of forest (Mukerji 2006). The ecodevelopment projects of the Great Himalayan National Park, Nanda Devi Biosphere Reserve, Hemis National Park, and Rajaji National Park in the Indian Himalaya are among the best examples (Badola et al. 2014). CF was introduced in Nepal in the late 1970s; now, 18,500 community forest user groups are managing more than 1 million ha of forest, accounting for about one-third of total forest area (MoFSC 2015a). In China, the Collective Forest Reform implemented in 2004 has given complete rights to local farmers to manage forestlands $\mathrm{Xu}$ et al. 2010). Pakistan formulated the National Forest Policy (MoCC 2015) to expand, protect, and promote sustainable use of forests, protected areas, natural habitats, and watersheds in order to restore their ecological functions and improve livelihoods and human health, in line with the national priorities and international agreements. The forest-rich areas of North West Frontier Province (now Khyber Pakhtunkhwa) in Pakistan saw an improvement in natural and financial capital for local people with the

Table 5.9 Community-based forest resource management practices and their coverage in the HKH

\begin{tabular}{l|l|l|l|l}
\hline Country & Terms used to denote participatory forest management & $\begin{array}{l}\% \text { forest in total } \\
\text { area of country }\end{array}$ & \multicolumn{2}{|l}{ Area of community forestry } \\
\cline { 5 - 5 } & & 2.0 & million ha & of country's forest area \\
\hline Afghanistan & Community-based forest management & 17.5 & NA & 0.0 \\
\hline Bangladesh & Social forestry & 70.4 & 0.07 & 2.5 \\
\hline Bhutan & Community based natural resources management & NA & NA & 58.0 \\
\hline China & Community-owned forests or collective forestlands & 3 & 21.0 & 28.5 \\
\hline India & Joint forest management & 27.1 & NA & NA \\
\hline Myanmar & Community forestry & 44.7 & 1.79 & 30.3 \\
\hline Nepal & Community forestry & 0.8 & 20.0 \\
\hline Pakistan & Community-based forest management of Guzara forests & NA &
\end{tabular}

$\mathrm{NA}=$ data not available 
Forestry Sector Project that institutionalized participatory forest management in the area (Ali et al. 2007).

The outcomes of these participatory and community-based approaches have largely had positive ecological, economic, and social impacts. Ecologically, regeneration of substantial areas of degraded forests has improved and there has been a visible impact in reversing the trend towards deforestation and forest degradation (Gurung et al. 2013). Socially, they have given institutional space for local communities to make their own decisions on a range of issues related to forests, income, inclusion, social justice, and so on. Economically, they have contributed to the economic opportunities available to local rural people (Xu et al. 2010; Birch et al. 2014). Bhutan, China, India, and Nepal have made good progress and Myanmar is trying hard to move, whereas Afghanistan, Bangladesh, and Pakistan have yet to make progress to achieve a visible impact from community forestry (Table 5.9). However, some of the approaches have limitations and shortcomings, such as elite capture, social disparity, inequitable benefit-sharing, and exclusion of poor and marginalized groups (Gurung et al. 2013). Special attention is needed to make participatory forestry inclusive with equitable benefit-sharing and a pro-poor focus.

\subsubsection{National and International Policies and Legislations-Support for Biodiversity Conservation}

The HKH has witnessed a significant paradigm shift for biodiversity conservation during the last few decades. The alarming forest condition of the Himalaya (Ives and Messerli 1989; Pandit et al. 2007), increasing human population and overexploitation of biodiversity (Sandhu and Sandhu 2014; Chettri and Sharma 2016), and the increasingly changing alpine meadow of the Tibetan Plateau (Klein et al. 2004; Luo et al. 2010) have highlighted numerous conservation and management challenges for biodiversity conservation in the region (see Sharma et al. 2009; Shrestha et al. 2012). However, with adaptive management and appropriate policies, the perception of conservation has changed significantly over the pre- and post-1992 periods (see Fig. 5.9). Since the new thinking in conservation and environmental management began in 1972 at the Stockholm conference, a number of key influential global developments have taken place. The Convention on Biological Diversity of 1992 (UN 1992) was an important milestone in the history of biodiversity conservation. Although a number of conventions were already in place before 1992 (such as the Ramsar Convention, World Heritage Convention, Convention on International Trade in Endangered Species of Wild Fauna and Flora, International Treaty on Plant Genetic Resources, and others), the CBD was instrumental in focusing on conservation and sustainable use of biodiversity (see Fig. 5.13).
The founding of the International Geosphere-Biosphere Programme and Millennium Development Goal agendas during 1992-2000 brought additional support. The perspective of biodiversity conservation totally changed when the Millennium Ecosystem Assessment (MA) processes advanced and the CBD initiated supporting programmes on PAs and mountain biodiversity during 2001-2010. With advancement of the MA, global communities accepted more strongly the concept of ecosystem services as a means of rationalizing the significance of biodiversity to human wellbeing, and the Intergovernmental Science-Policy Platform on Biodiversity and Ecosystem Services (IPBES) was established. Progressive change continued in the global arena with the 2020 Aichi targets in 2010 and Sustainable Development Goals and UNFCCC Paris Agreement in 2015 (Fig. 5.13).

In the HKH, several policies were formulated and practised before 1992, beginning with the Forest Act 1927, which is still instrumental in India and Pakistan. This was followed by the Wildlife Protection Act of 1972 in India and the Islamabad Wildlife (Protection, Preservation, Conservation, and Management) Ordinance 1979 in Pakistan. In Nepal, the National Parks and Wildlife Conservation Act of 1973 was the pioneering legal instrument, while the first formal conservation instrument in China was the law on the Protection of Wildlife 1988. Since 1999, China has been addressing deforestation progressively with the 'Green for Grain' policy and practices, with commendable success (Box 5.3). The first national policy for Bhutan was the forest policy formulated in 1974; which was followed by the Forest and Nature Conservation Act 1995, which dedicates two chapters to biodiversity conservation, with several sections on PAs and conservation of wildlife.

\section{Box 5.3 Grain for green}

The Grain-for-Green policy, the largest land reforestation/afforestation program in China, was launched in 1999 to mitigate land degradation by returning steeply sloping cultivated land to forest or grassland. Although the initiative showed variations, it has contributed significantly leading to a doubling of forest cover and increased carbon sequestration (Chen et al. 2015b). The value of nutrient cycling, regulating gases, organic material provision, and soil conservation increased by $64,39,40$, and $18 \%$, respectively (Song et al. 2015). The initiative is expected to sequester $110.45 \mathrm{Tg} \mathrm{C}$ by 2020 , and $524.36 \mathrm{Tg} \mathrm{C}$ by the end of the century, with economic benefits ranging from USD 8.84-44.20 billion between 2000 and 2100, which may exceed the current total investment (USD 38.99 billion) on the program (Liu et al. 2014). The results indicate that a large-scale initiative with policy support can bring significant change towards addressing climate change. 


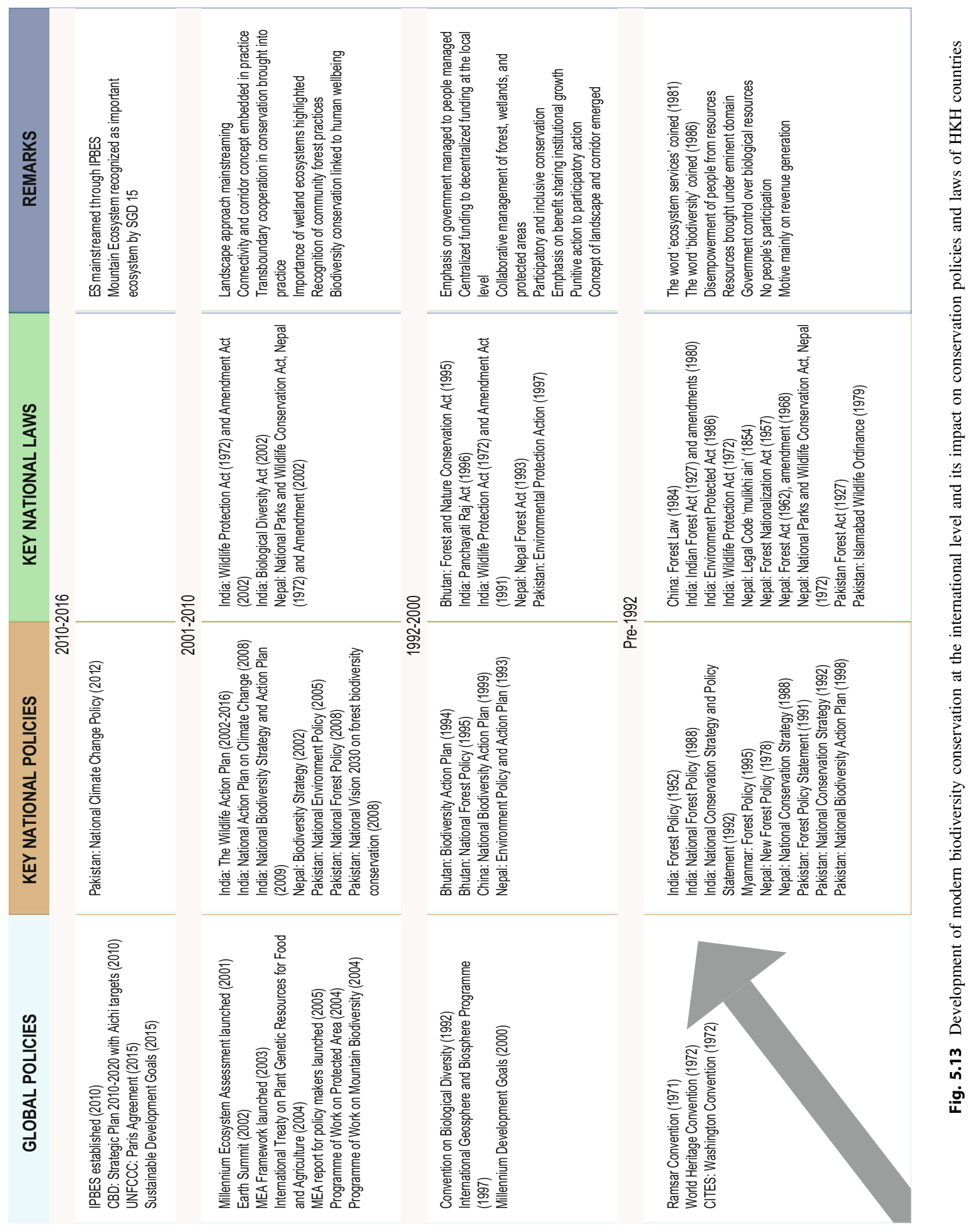


Many of the earlier versions of policies and laws prohibit human influences on an ecosystem once the area has been declared as a national park or wetland of international importance. Even areas outside PAs may be under forest or wetland law in which usufruct rights were denied to the local communities. As a result, the degradation of Himalayan ecosystem was strongly predicted during this time (Ives and Messerli 1989). To address Himalayan degradation and other conservation issues, from 1992, the policies and legislation in the Himalayan countries were amended and improved several times and new laws for local resources management were promulgated, mainly driven by the global development and establishment of numerous conventions, including the CBD. The Panchayat (Extension to Scheduled Areas) Act 1996 and Biological Diversity Act 2002 in India, and the Conservation Area Rules 1996, National Parks and Wildlife Conservation Act (1972) and its amendment (1993), Forest Act (1993), Forest Policy (2015), and Buffer Zone Management Regulation 1996 in Nepal are good examples of policy changes towards conservation. Each case represented, in several fundamental ways, a devolution of control from government authorities to local communitiesa major shift. As an adaptive social process, these moves strived to create sufficient future forest opportunity to satisfy potentially competitive/conflicting interests that would diminish the forest if left unresolved (Singh et al. 2010). The change has been further boosted by the declaration of the National Mission for Green India targeting the afforestation of 6 million hectares of degraded forest lands and expanding forest cover from 23 to $33 \%$ of India's territory through people's involvement, and enlarging the landscape under conservation (GoI 2008). The development of modern biodiversity conservation at the international level and its impact on the conservation policies and laws of $\mathrm{HKH}$ countries (Fig. 5.13) has brought about a new paradigm in conservation and sustaining ecosystem services in the HKH.

\subsection{Sustaining Ecosystems-Challenges, Opportunities, and Strategies}

The local communities in the HKH face uncertainties and challenges as they strive to use, nurture, and sustain the diverse ecosystems at landscape scale where they live and on which they depend. The most powerful contemporary forces that influence both biological and cultural diversity and livelihoods include government policies, expansion of regional and global markets, and climate change, among others. Some of these forces are positive, others are not (Xu and Grumbine 2014a). With increasing awareness of upstream and downstream linkages, biodiversity and ecosystem services have been recognized for their ecological, sociocultural, and economic values (Rasul 2014). While acknowledging that some indigenous communities are more resilient than others, the knowledge, innovations, and practices of local groups can be strengthened with appropriate assistance from partnerships with governments, non-governmental organizations, and the commercial sector to ensure equitable access and sustainable management of natural resources. These partnerships must be based on participatory processes, intercultural dialogues, and co-designing and co-production of hybrid knowledge among different stakeholders (Xu and Grumbine 2014b). They are also an important instrument for ecological restoration and poverty alleviation, especially in the upstream headwater areas (Grêt-Regamey et al. 2012; Sandhu and Sandhu 2014; Bawa and Seidler 2015; Feng et al. 2016). There are examples where increasing financial investment is being made for conservation and restoration of ecosystems. China has launched the Natural Forest Conservation Program (NFCP) and Sloping Land Conversion Program (SLCP), the largest payment for ecosystem service programs in human history (Uchida et al. 2005; Chen et al. 2015b). The cumulative total investment through the NFCP and SLCP exceeds USD 50 billion, and the SLCP alone benefits more than 120 million farmers in 32 million households (Ouyang et al. 2016). Ecosystem sustainability has been increasingly integrated into environmental, biodiversity conservation, and sustainable development agendas (Maselli 2012; Secretariat of CBD 2014; Díaz et al. 2015). The current trends of environmental degradation and the effects of projected climate change in the region necessitate the inclusion of local knowledge and institutions into environment management and conservation practices driven by cutting edge science.

This global natural capital and the Himalayan 'water tower' have been facing multiple drivers of change (see Chettri and Sharma 2016; Chap. 2). Traditional drivers such as deforestation, habitat loss, habitat degradation and fragmentation, overharvesting of biological resources, illegal hunting and poaching, monoculture plantation, agricultural intensification and loss of genetic resources, shifting cultivation with insufficient fallow period, human-wildlife conflict and livestock and crop depredation, invasive alien species, and atmospheric pollution are often recognized as having an adverse impact on conservation and sustainable use of biodiversity and ecosystem services (Aryal and Kerkhoff 2008; Zomer and Oli 2011; Chettri and Sharma 2016; ICIMOD, WCD, GBPNIHESD, RECAST 2017). However, the effects of indirect drivers related to socioeconomic and sociocultural factors, urbanization, poverty, and poor governance and weak institutional frameworks are poorly understood and managed. The HKH has become a centre of rapid and unplanned development through mining operations, urbanization, haphazard construction of dams for hydropower, and poorly planned and constructed roads 
resulting in changes in this vulnerable and fragile region (Pandit and Grumbine 2012; Pandit et al. 2014). Though at varied scales, forest degradation has been continuous across the HKH except Bhutan (Pandit et al. 2007; Uddin et al. 2015; Chakraborty et al. 2016). The impacts of climate change add to the severity of the problems in the area and have been prominently featured as one of the drivers (Xu et al. 2009a; Shrestha et al. 2012), and alien and invasive species have visibly altered the overall composition of the ecological variables (Kohli et al. 2004; Bhattarai et al. 2014). The direction and trends predicted for climate change and bioclimatic conditions generally indicate accelerated change and major disruption for the region (Shrestha et al. 2012). Rising temperatures, changes in precipitation patterns, and reduction in the volume of glaciers (Xu et al. 2009a; Panday et al. 2014) create a host of cascading effects and will have a major impact on ecosystems, biodiversity, and livelihoods throughout the region (Immerzeel et al. 2013; Zomer et al. $2014,2015,2016)$. The changes have resulted in a decrease in the resilience capacity of the natural systems which is impacting human wellbeing.

There is increasing evidence of the impacts of climate change on biodiversity and ecosystems. Instances of changes in phenology (Ranjitkar et al. 2013; Hart et al. 2014) and shifts of species towards higher elevation (Valley 2003; Joshi et al. 2012; Brandt et al. 2013b; Telwala et al. 2013) have been reported. Such changes are likely to be profound with extraordinary levels of biotic perturbation (Shrestha et al. 2012). Overall, the ability of species to respond to climate change will largely depend on their ability to 'track' the shifting climate by colonizing new territory or to modify their physiology and seasonal behaviour (such as periods of flowering or mating) to adapt to the changed conditions (Thuiller et al. 2008). The efficiency of species' responses under climate change is likely to be highly idiosyncratic and difficult to predict (La Sorte and Jetz 2010). The heterogeneity of the mountain terrain provides both biological refugia and natural dispersal corridors, but can also present a variety of challenges to the migration of species. Niches for shifting mountain species along elevational gradients decrease in size with increasing elevation, or disappear at the mountains' top (Körner 2007). Likewise, rapid changes in seasonal variations, such as the timing and length of the growing season, or warmer winter temperatures, perturb ecosystem functioning, disrupting finely tuned pollinator interactions (as when cycles between the insect and the plant it specializes on become unsynchronized), affecting emergence or migration of either predator or prey species, or allowing for the overwintering and survival of pests and pathogens.

Many of these impacts can be expected to manifest before 2050 (Mora et al. 2015; Zomer et al. 2016). The cascading effects will also impact agricultural and pastoral systems (Maikhuri et al. 2001). Agricultural systems, mountain communities, and mountain livelihoods are susceptible and will be profoundly affected. Local communities, highly dependent upon ES, may be able to adapt through the expansion of cropping systems into new areas, the introduction of new varieties or new technologies, or the modification of existing production practices, and by relying on traditional ecological knowledge for coping with variability and maintaining socio-ecological resilience. The highly diverse and environmentally fine-tuned agrobiodiversity of this region may both provide options and be threatened, including the many genetic lines and landraces of various important food crops and livestock breeds found in the HKH. Although conditions may possibly improve for production in places (e.g., warmer and wetter), erratic and highly variable patterns of rainfall, increases in extreme events, occurrence of drought, or changes in the intensity and duration of the monsoon will create major adaptation challenges (Ramesh and Goswami 2007).

The magnitude and speed of these bioclimatic changes are likely to have an impact on the conservation effectiveness of the many PAs and other conservation efforts within the HKH (La Sorte and Jetz 2010; Zomer et al. 2015). For example, ecological conditions within PAs may change beyond limits conducive for the species currently found there as species ranges shift. The ability to survive, adapt to, or benefit from the changes is species- and site-specific and depends on factors such as population dynamics, seed dispersal mechanisms, habitat availability and/or fragmentation, and physiological adaptability (Corlett and Westcott 2013). Improving our understanding of the responses of the species found in the $\mathrm{HKH}$ is imperative if conservation strategies and policies designed to meet these challenges are to be effective. This is equally true for maintaining agricultural production for food security and contributing to sustainable development in the $\mathrm{HKH}$, particularly concerning the traditional mountain agricultural systems found in the region, which are generally highly adapted to specific climatic niches within the highly heterogeneous mountainous terrain.

The challenges could be translated into opportunities through development and implementation of appropriate strategies. The core issue identified from the analysis so far indicates that transformative changes have mainly been driven by either a constantly changing climate or land use change to enhance production systems to address resource crises due to the increasing demand of a growing population. The effectiveness of governance systems and implementation of evolving policies also needs special attention. The following broad strategic direction could be useful for long-term resolution. 


\subsubsection{An Integrated Approach-The Landscape as a Socio-Ecological System}

Humans, unlike any other multicellular species in Earth's history, have emerged as a global force that is transforming the ecology of the entire planet. It is no longer possible to understand, predict, or successfully manage ecological patterns, processes, or change without understanding why and how humans reshape these over the long term. To investigate, understand, and address the ultimate causes of anthropogenic ecological change, not just the consequences, human sociocultural processes must become as much a part of ecological theory and practice as biological and geophysical processes are now. The 240 million people living in the HKH are strongly linked to the ecosystem health of the region that ensures the continuous flow of services for their subsistence livelihood (Xu et al. 2009a). This intricate linkage between ecosystem and human wellbeing has been shaping the ecosystems and helping in supporting diversity (Gorenflo et al. 2012). More important, this diversity, which also addresses poverty, needs socio-ecological understanding (Gerlitz et al. 2012).

The state of biodiversity and ecosystem services in the HKH is rapidly changing due not only to increasing synergistic effects of anthropogenic and natural drivers but also to weak governance and institutions' limited capacity to cope with such changes. An integrated, gender- and socially-inclusive, and national and inter-regional enabling policy approach can help in reforming governance policies and institutional and legal frameworks, and promote conservation and sustainable use of biodiversity and ecosystem services. The diverse ecosystems support tourism, agricultural production, water security, and clean energy development downstream. To sustain these services, and to ensure food, water, and energy security in the $\mathrm{HKH}$, management of ecosystems including forests, wetlands, and rangelands is crucial (Rasul 2014). With increasing demand for and scarcity of land, water, energy, and natural resources for competing uses, the challenge is to minimize trade-offs and maximize synergies. Though the region has long witnessed a sectorial approach for conservation and development, it is essential to address the complexity of the HKH ecosystem and people's dependency through a cross-sector coordinated approach. Mountain tourism is one example where biodiversity conservation, cultural preservation, socioeconomic development, and environmental aspects could be better linked and coordinated (Nepal 2013). The socio-ecological systems are best dealt with by using a landscape approach (Sayer 2009). Strongly grounded in transdisciplinarity, the landscape approach has the potential to maximize synergy and secure integrated actions by multiple stakeholders (MoFSC 2016; ICIMOD, WCD, GBPNIHESD, RECAST 2017). The principles of the landscape approach, including transdisciplinarity, have been widely shared and applied across the countries of the HKH with varying degrees of success (Chettri and Sharma 2016). These principles have also been endorsed by the intergovernmental process dealing with biodiversity conservation and climate change mitigation and adaptation (Sayer et al. 2013). This approach could be used at different scales considering the linkages for raising the adaptive capacity of people and resilience of ecosystems. The river basin, landscape, and ecosystem approaches practised in the region could be further strengthened for better synergy and coordination (Rasul 2014; Chettri and Sharma 2016).

\subsubsection{Building Knowledge - Science in Support of Decision-Making}

Science-based knowledge development in the HKH is currently undergoing a remarkable transformation driven by (1) new technologies for linking, producing and processing ecological information; (2) increasing economic interest in natural resources from the mountains; (3) the rising prominence of markets, even in remote villages; (4) greater awareness of ecological crises; and (5) efforts to expand the participation of communities in ecological governance (Oli et al. 2013; Molden et al. 2014b). There has been considerable work on the production of ecological knowledgelocal knowledge, indigenous knowledge, gendered knowledge, and ethno-ecological knowledge (Khadka and Verma 2012; Uprety et al. 2016). This work has identified issues of competing knowledge, access, and representation of different social groups. There has also been considerable discussion about how to integrate local knowledge, scientific knowledge, and decision sciences, especially state policies. The last decades in the HKH have seen the emergence of new technologies (information technology, geo-spatial tools, and participatory approaches), new actors (youths, academic institution), new values, new institutions (civil society, international development partners), and new territories that have come to play an integral role in ecological decision-making and participation. There is an increasing imperative to explore how diverse ecological knowledge can enter into evolving governance practice. The key question is, how does this knowledge transformation influence the varying capacities of these actors to shape their worlds through these valuations and understanding, and through ecological governance in the HKH and beyond? There is an increasing trend to bring together scientific scholars, graduate students, and community-oriented partners to mobilize ecological knowledge in the HKH. For example, the National Natural Science Foundation of China has launched a regular funding mechanism for scientific research in ecology on the edge of the Tibetan Plateau and Himalaya, 
and the National Mission for Sustaining the Himalayan Ecosystem (NMSHE) and National Mission for Himalayan Studies (NMHS) in India have been launched to broaden the scientific knowledge base in the Indian Himalayan Region to inform policy and practice (GoI 2016, 2017).

\subsubsection{Regional Cooperation for Regional Challenges and Opportunities}

The ecosystems of the HKH are diverse and the distribution among countries heterogeneous, but the majority of them are contiguous across borders (Xu et al. 2009a) and many of the globally significant ecoregions are shared by different countries (Olson and Dinerstein 2002). Even the environmental strata are contiguous across countries providing upstream and downstream linkages (Zomer et al. 2016). Many iconic species also have a wider habitat and range across different countries (Dorji et al. 2012; Forrest et al. 2012; Kandel et al. 2015). Many of the HKH countries have also developed a strong interdependence in trade, culture, and tourism (Chettri 2011). Traditional barter systems are still prevalent in remote areas of Nepal and China (Chaudhary et al. 2015a, b). There are also instances of wildlife trade and human-wildlife conflict across borders (Rao et al. 2011; Acharya et al. 2016), while numerous PAs are also transboundary in nature (IUCN 2005; Chettri et al. 2008), and many conservation issues demand regional cooperation. Pereira et al. (2010) have indicated a scenario in which biodiversity will continue to decline over the 21st century; however, the range of projected change is much broader than most studies suggest, partly because there are major opportunities to intervene through better policies, but also because of large uncertainties in projections. This strongly suggests the need to fill the gaps in research-based knowledge, and develop management and communication strategies focusing on multiple sources and approaches that lead to policy intervention. To translate this range of conservation and development challenges into opportunities for sustainable development, regional cooperation among the countries sharing such critical ecosystems will be essential.

\subsubsection{National and Global Investment- Securing Future of Biodiversity and Ecosystem Services}

Investment in conservation is a wise trade-off for sustaining the continuous flow of ES, enhancing ecosystem resilience, and ensuring a bright future for coming generations. However, the investment is not happening where it is most needed (Wilson et al. 2016). The HKH hosts four of the world's 36 biodiversity hotspots (Mittermeier et al. 2011) and is vulnerable to various drivers of change including climate change. However, the investment in conservation and management has faced disparity and been given low priority even by developing countries (Watson et al. 2016). It was observed that China and Nepal are among the top in investing on gross domestic expenditure on research and development (Katsnelson 2016). It is high time for conservation communities to plan investment based on the priority areas where biodiversity is declining at an accelerated rate (Waldron et al. 2013). Though the conservation investment by $\mathrm{HKH}$ countries is at different stages due to varying priorities and resource availability, the countries need to set aside more investment as a trade-off for sustainable development goals.

\subsection{Conclusion}

The HKH region is the source of ten major river systems and includes all or parts of four global biodiversity hotspots. The rich biodiversity and diverse ecosystems play a critical role in sustaining the wellbeing of the 240 million people of the region, and the goods and services from the mountain ecosystem are estimated to benefit a further 1.7 billion people in the downstream areas. The diverse ecosystems provide services with four values: social - for public benefit, cultural - for aesthetic and communal significance, ecological-for environmental conservation and sustainability, and economic - for livelihoods through production of goods and services. However, these services are poised for major changes in the current scenario of threats, chiefly as a result of climate change; local, regional and global market forces; and the socio-political environment prevalent in individual countries. There are other factors like cross-sectoral policies and strategies that will have a potential impact on ecosystems, while the lack of interdisciplinary understanding and knowledge, governance systems, consumption patterns of a large and growing urban population, and others have further impacted biodiversity and the functions and flow of services from ecosystems. Equally, these threats and their drivers have provide the stakeholders of the HKH with an opportunity for closer regional co-operation at all levels, especially for sharing knowledge, practice, and experience to develop robust strategies for managing the socio-ecological systems that are dependent on the sustained flow of ecosystem services. There has been an unprecedented effort made towards finding innovations and going beyond conventional approaches in managing these life-supporting systems (e.g., from a species to a landscape and ecosystem approach). Yet much remains to be done to reach a stage where we can claim that there is adequate resilience in the ecosystems and the communities to withstand the threats brought about by large local, regional, and global changes.

Regional co-operation needs further strengthening at the government, civil society, private sector, and community 
levels. Policies and their implementation have yet to reflect the integration that is required across different sectors to address some of the challenges mentioned above. Decision makers at all levels need to be empowered and equipped with information and knowledge that is holistic, interdisciplinary, and exemplified with best practices from elsewhere. Further, there need to be large-scale studies and research to enhance knowledge and information about the four values that biodiversity and ecosystem services provide for informed decision making.

One of the critical factors for achieving some of the aspirations mentioned above is to have more investment in the HKH region from donors, governments, and the private sector to ensure the sustainability of the assets while pursuing the larger goals of poverty alleviation, economic development, and overall human wellbeing.

\section{References}

Aase, T., Chaudhary, R. P., \& Vetaas, O. R. (2009). Farming flexibility and food security under climatic security: Manang, Nepal Himalaya. Area, 1-9. https://doi.org/10.1111/j.1475-4762.2009. 00911.x.

Aase, T. H., Chapagain, P. S., \& Tiwari, P. C. (2013). Innovation as an expression of adaptive capacity to change in Himalayan farming. Mountain Research and Development, 33(1), 4-10.

Abler, D. (2004). Multifunctionality, agricultural policy, and environmental policy. Agricultural and Resource Economics Review, 33, $8-17$.

Acharya. (2015). A walk to a zero poaching of Rhino. Department of National Park and Wildlife Conservation, Ministry of Forest and Soil Conservation, Government of Nepal.

Acharya, B. K., \& Sharma, G. (2012). The traditional Dzumsa system and their role in resource management in cultural landscape in North Sikkim. Cultural Landscape, 175.

Acharya, B. K., Sanders, N. J., Vijayan, L., \& Chettri, B. (2011). Elevational gradients in bird diversity in the Eastern Himalaya: An evaluation of distribution patterns and their underlying mechanisms. PLOS ONE, 6(12), e29097. https://doi.org/10.1371/journal.pone. 0029097

Acharya, K. P., Paudel, P. K., Neupane, P. R., \& Köhl, M. (2016). Human-wildlife conflicts in Nepal: Patterns of human fatalities and injuries caused by large mammals. PLOS ONE, 11(9), e0161717.

Ahmad, A., \& Nizami, S. M. (2015). Carbon stocks of different land uses in the Kumrat valley, Hindu Kush region of Pakistan. Journal of Forestry Research, 26(1), 57-64.

Ale, S. B., Shrestha, B., \& Jackson, R. (2014). On the status of snow leopard Panthera uncia (Schreber, 1775) in Annapurna, Nepal. Journal of Threatened Taxa, 6(3), 5534-5543. http://dx.doi.org/10. 11609/JoTT.03635.5534-43.

Alexander, J. S., Zhang, C., Shi, K., \& Riordan, P. (2016). A granular view of a snow leopard population using camera traps in Central China. Biological Conservation, 197, 27-31.

Ali, T., Ahmad, M., Shahbaz, B., \& Suleri, A. (2007). Impact of participatory forest management on vulnerability and livelihood assets of forest-dependent communities in Northern Pakistan. The International Journal of Sustainable Development \& World Ecology, 14(2), 211-223.
Allen, D. J., Molur, S., \& Daniel, B. A. (2010). The status and distribution of freshwater biodiversity in the Eastern Himalaya. IUCN.

Amin, R., Thomas, K., Emslie, R. H., Foose, T. J., \& Van Strien, N. (2006). An overview of the conservation status of and threats to rhinoceros species in the wild. International Zoo Yearbook, 40, 96117.

Anand, A., Chandan, P., \& Singh, R. B. (2012). Homestays at Korzok: Supplementing rural livelihoods and supporting green tourism in the Indian Himalayas. Mountain Research and Development, 32(2), $126-136$.

ANBSAP. (2013). Afghanistan's national biodiversity strategy and action plan. Government of the Islamic Republic of Afghanistan.

Anderson, D. M., Salick, J., Moseley, R. K., \& Xiaokun, O. (2005). Conserving the sacred medicine mountains: A vegetation analysis of Tibetan sacred sites in Northwest Yunnan. Biodiversity and Conservation, 14(13), 3065-3091.

Anthwal, A., Gupta, N., Sharma, A., Anthwal, S., \& Kim, K. H. (2010). Conserving biodiversity through traditional beliefs in sacred groves in Uttarakhand Himalaya, India. Resources, Conservation and Recycling, 54(11), 962-971.

Arora, V. (2006). The forest of symbols embodied in the Tholung sacred landscape of North Sikkim. India. Conservation and Society, 4(1), 55.

Aryal, K. P., \& Kerkhoff., E. E. (2008).The right to practice shifting cultivation as a traditional occupation in Nepal: A case study to apply ILO Conventions Nos. 111 (Employment and Occupation) and 169 (Indigenous and Tribal Peoples). Kathmandu: International Labour Office, 2008. ISBN 978-92-2-121452-6.

Awasthi, A., Uniyal, S. K., Rawat, G. S., \& Rajvanshi, A. (2003). Forest resource availability and its use by the migratory villages of Uttarkashi, Garhwal Himalaya (India). Forest Ecology and Management, 174(1), 13-24.

Badola, R., Hussain, S. A., Mishra, B. K., Konthoujam, B., Thapliyal, S., \& Dhakate, P. M. (2010). An assessment of ecosystem services of Corbett Tiger Reserve, India. The Environmentalist, 30(4), 320 329.

Badola, R., Hussain, S. A., Dobriyal, P., \& Barthwal, S. (2014). An integrated approach to reduce the vulnerability of local communities to environmental degradation in Western Himalayas. India: Study Report, Wildlife Institute of India.

Bajracharya, B., Uddin, K., Chettri, N., Shrestha, B., \& Siddiqui, S. A. (2010). Understanding land cover change using a harmonized classification system in the Himalaya: A case study from Sagarmatha National Park. Nepal. Mountain Research and Development, 30(2), 143-156.

Bajracharya, S. B., Chaudhary, R. P., \& Basnet, G. (2015). Biodiversity conservation and protected area management in Nepal. Nepal-An introduction to the natural history, ecology and human environment in the Himalayas: A companion to the Flora of Nepal (pp. 473486). Edinburgh, UK: Royal Botanic Garden.

Banskota, K., Karky, B., \& Skutsch, M. (2007). Reducing carbon emissions through community-managed forests in the Himalaya. International Centre for Integrated Mountain Development (ICIMOD).

Barlow, M., Wheeler, M., Lyon, B., \& Cullen, H. (2005). Modulation of daily precipitation over Southwest Asia by the Madden-Julian oscillation. Monthly Weather Review, 133(12), 3579-3594.

Basnet, G., \& Chaudhary, R. P. (2017). Indigenous system of pastureland management: A case of Limi in the Kailash sacred landscape, Nepal. In M. Karki, R. Hill, W. Alangui, K. Ichikawa, \& P. Bridgewater (Eds.), Knowing our lands and resources (pp. 8693). Paris: United Nations Educational Scientific and Cultural Organization (UNESCO). 
Baumgärtner, S., \& Quaas, M. (2010). What is sustainability economics? Ecological Economics, 69(3), 445-450.

Bawa, K. S. (2006). Globally dispersed local challenges in conservation biology. Conservation Biology, 20(3), 696-699.

Bawa, K. S., \& Seidler, R. (2015). Deforestation and sustainable mixed-use landscapes: A view from the Eastern Himalaya. Annals of the Missouri Botanical Garden, 100(3), 141-149.

Bennett, E. M., Peterson, G. D., \& Gordon, L. J. (2009). Understanding relationships among multiple ecosystem services. Ecology Letters, 12(12), 1394-1404.

Bhardwaj, M., Uniyal, V. P., Sanyal, A. K., \& Singh, A. P. (2012). Butterfly communities along an elevational gradient in the Tons valley, Western Himalayas: Implications of rapid assessment for insect conservation. Journal of Asia-Pacific Entomology, 15(2), 207-217.

Bhat, J. A., Iqbal, K., Kumar, M., Negi, A. K., \& Todaria, N. P. (2013). Carbon stock of trees along an elevational gradient in temperate forests of Kedarnath Wildlife Sanctuary. Forest Science and Practice, 15(2), 137-143.

Bhattarai, K. R., Måren, I. E., \& Subedi, S. C. (2014). Biodiversity and invasibility: Distribution patterns of invasive plant species in the Himalayas. Nepal. Journal of Mountain Science, 11(3), 688-696.

Birch, J. C., Thapa, I., Balmford, A., Bradbury, R. B., Brown, C., Butchart, S. H., et al. (2014). What benefits do community forests provide, and to whom? A rapid assessment of ecosystem services from a Himalayan forest, Nepal. Ecosystem Services, 8, 118-127.

Blaikie, P. M., \& Muldavin, J. S. (2004). Upstream, downstream, China, India: the politics of environment in the Himalayan region. Annals of the Association of American Geographers, 94(3), 520 548.

Brandt, S. A. (2000). Classification of geomorphological effects downstream of dams. CATENA, 40(4), 375-401.

Brandt, J. S., Wood, E. M., Pidgeon, A. M., Han, L. X., Fang, Z., \& Radeloff, V. C. (2013a). Sacred forests are keystone structures for forest bird conservation in southwest China's Himalayan Mountains. Biological Conservation, 166, 34-42.

Brandt, J. S., Haynes, M. A., Kuemmerle, T., Waller, D. M., \& Radeloff, V. C. (2013b). Regime shift on the roof of the world: Alpine meadows converting to shrublands in the Southern Himalayas. Biological Conservation, 158, 116-127.

Brooks, T. M., Mittermeier, R. A., da Fonseca, G. A., Gerlach, J., Hoffmann, M., Lamoreux, J. F., et al. (2006). Global biodiversity conservation priorities. Science, 313(5783), 58-61.

Brush, S. B. (1995). In situ conservation of landraces in centers of crop diversity. Crop Science, 35(2), 346-354.

Bubela, T., \& Gold, E. R. (2012). Genetic resources and traditional knowledge: Case studies and conflicting interests. Cheltenham: Edward Elgar Publishing.

Cardinale, B. J., Palmer, M. A., \& Collins, S. L. (2002). Species diversity enhances ecosystem functioning through interspecific facilitation. Nature, 415(6870), 426-429.

CBS. (2014). Environmental Statistics of Nepal-2013. Kathmandu: Central Bureau of Statistics.

CCD. (2014). Fifth national report-Pakistan. Government of Pakistan: Climate Change Division.

Chakraborty, A., Sachdeva, K., \& Joshi, P. K. (2016). Mapping long-term land use and land cover change in the central Himalayan region using a tree-based ensemble classification approach. Applied Geography, 74, 136-150.

Chan, K. M., Guerry, A. D., Balvanera, P., Klain, S., Satterfield, T., Basurto, X., et al. (2012). Where are cultural and social in ecosystem services? A framework for constructive engagement. BioScience, 62(8), 744-756.
Chandola, S. (2012). An assessment of human wildlife interaction in the Indus Valley, Ladakh, Trans-Himalaya. Doctoral dissertation, $\mathrm{Ph}$. D. thesis submitted to Saurashtra University, Rajkot (Unpublished). Chaudhary, R. P., Uprety, Y., Joshi, S. P., Shrestha, K. K., Basnet, K. B., Basnet, G., et al. (2015a). Kangchenjunga Landscape Nepal: From conservation and development perspectives. Kathmandu, Nepal: Ministry of Forests and Soil Conservation (MoFSC), Government of Nepal; Research Centre for Applied Science and Technology (RECAST), Tribhuvan University; and International Centre for Integrated Mountain Development (ICIMOD).

Chaudhary, S., McGregor, A., Houston, D., \& Chettri, N. (2015b). The evolution of ecosystem services: A time series and discoursecentered analysis. Environmental Science \& Policy, 54, 25-34.

Chaudhary, R. P., Uprety, Y., and Rimal, S. K. (2016a). Deforestation in Nepal: Causes, consequences and responses. In R. Sivanpillai \& J. F. Shroder (Eds.), Biological and environmental hazards and disasters (pp. 335-372). Elsevier Inc.

Chaudhary, S, Chettri N, Uddin, K, Khatri TB, Dhakal, M, Bajracharya, B., et al. (2016). Implications of land cover change on ecosystem services and people's dependency. A case study from the Koshi Tappu Wildlife Reserve, Nepal. Ecological Complexity. https://doi.org/10.1016/j.ecocom.2016.04.002.

Chaudhary, R. P., Bhattarai, S. H., Basnet, G., Bhatta, K. P., Uprety, Y., Bhatta, L. D., et al. (2017). Traditional practice and knowledge of indigenous and local communities in Kailash Sacred Landscape, Nepal. ICIMOD Working Paper 2017/1. Kathmandu: ICIMOD.

Chen, F. H., Dong, G. H., Zhang, D. J., Liu, X. Y., Jia, X., An, C. B., et al. (2015a). Agriculture facilitated permanent human occupation of the Tibetan Plateau after 3600 B.P. Science 345(6219), 248.

Chen, Y., Wang, K., Lin, Y., Shi, W., Song, Y., \& He, X. (2015b). Balancing green and grain trade. Nature Geoscience, 8(10), 739.

Chettri N. (2011). Role of actors and institutions in cross border tourism development. In Proceedings on integrated tourism concepts to contribute to sustainable development in mountain regions, 15-22 June 2009 (pp. 154-170). Kathmandu \& Jomsom, Nepal: ICIMOD and InWent.

Chettri, N., \& Sharma, E. (2016). Reconciling the mountain biodiversity conservation and human wellbeing: Drivers of biodiversity loss and new approaches in the Hindu-Kush Himalayas. Proceedings of the Indian National Science Academy, 82, 53-73.

Chettri, N., Shakya, B., Thapa, R., \& Sharma, E. (2008). Status of protected area system in the Hindu Kush Himalaya: an analysis of PA coverage. International Journal of Biodiversity Science and Management., 4(3), 164-178.

Chettri, N., Sharma, E., Shakya, B., Thapa, R., Bajracharya, B., Uddin, K., et al. (2010) Biodiversity in the Eastern Himalayas: Status, trends and vulnerability to climate change. Climate change impact and vulnerability in the Eastern Himalayas-Technical report 2 (p. 23). Kathmandu: ICIMOD.

Chettri, N., Sharma, E., Shrestha, A. B., Zhoali, Y., Hua, Q., \& Bajracharya, B. (2012). Real world protection for the third pole and its people. In F. Huettmann (Ed.), Protection of Polar Regions (pp. 113-133). Japan: Springer.

Choudhary, A. U. (2001). An overview of the status and conservation of the red panda in India, with reference to its global status. Oryx, $35,250-259$.

Chowdhury, M. S. H., \& Koike, M. (2010). An overview on the protected area system for forest conservation in Bangladesh. Journal of Forestry research, 21(1), 111-118.

Conservation International. (2016). Biodiversity hotspots. Retreived 22 September 2016.

Corlett, R. T., \& Westcott, D. A. (2013). Will plant movements keep up with climate change? Trends in Ecology \& Evolution, 28(8), 482488. 
Costanza, R., Howarth, R. B., Kubiszewski, I., Liu, S., Ma, C., Plumecocq, G., et al. (2016). Influential publications in ecological economics revisited. Ecological Economics, 123, 68-76.

Creed, I. F., Weber, M., Accatino, F., \& Kreutzweiser, D. P. (2016). Managing forests for water in the Anthropocene-The best kept secret services of forest ecosystems. Forests, 7(3), 60.

Dangi, M. B., Chaudhary, R. P., Rijal, K., Stahl, P. D., Belbase, S., Gerow, K. G., et al. (2017). Impacts of environmental change on agroecosystems and livelihoods in Annapurna Conservation Area. Nepal: Environmental Development (In press).

Daniel, T. C., Muhar, A., Arnberger, A., Aznar, O., Boyd, J. W., Chan, K. M., et al. (2012). Contributions of cultural services to the ecosystem services agenda. Proceedings of the National Academy of Sciences, 109(23), 8812-8819.

de Groot, R. S., Alkemade, R., Braat, L., Hein, L., \& Willemen, L. (2010). Challenges in integrating the concept of ecosystem services and values in landscape planning, management and decision making. Ecological Complexity, 7(3), 260-272.

Desai, B. H., Oli, K. P., Yang, Y., Chettri, N., \& Sharma, E. (2011). Implementation of convention on biological diversity: A retrospective analysis in the Hindu Kush Himalayan Countries (p. 33). Kathmandu, Nepal: ICIMOD.

Deterra, H. (1937). Cenozoic cycles in Asia and their bearing on human prehistory. Proceedings of the American Philosophical Society, 289-308.

Díaz, S., Demissew, S., Carabias, J., Joly, C., Lonsdale, M., Ash, N., et al. (2015). The IPBES conceptual framework-Connecting nature and people. Current Opinion in Environmental Sustainability, 14, 1-16.

Dinerstein, E., \& Price, L. (1991). Demography and habitat use by greater one-horned rhinoceros in Nepal. The Journal of Wildlife Management, 401-411.

DoE. (2015). Fifth national report of Bangladesh to the convention on biological diversity. Ministry of Environment and Forests, Government of the Peoples Republic of Bangladesh, Dhaka.

Dong, S., Wen, L., Zhu, L., \& Li, X. (2010). Implication of coupled natural and human systems in sustainable rangeland ecosystem management in HKH region. Frontiers of Earth Science in China, 4 (1), 42-50

Dorji, S., Rajaratnam, R., \& Vernes, K. (2012). The Vulnerable red panda Ailurus fulgens in Bhutan: Distribution, conservation status and management recommendations. Oryx, 46(04), 536-543.

Dudley, N., Higgins-Zogib, L. I. Z. A., \& Mansourian, S. (2009). The links between protected areas, faiths, and sacred natural sites. Conservation Biology, 23(3), 568-577.

Dunn, J. C., Buchanan, G. M., Stein, R. W., Whittingham, M. J., \& McGowan, P. J. (2016). Optimising different types of biodiversity coverage of protected areas with a case study using Himalayan Galliformes. Biological Conservation, 196, 22-30.

Ebi, K. L., Woodruff, R., von Hildebrand, A., \& Corvalan, C. (2007). Climate change-related health impacts in the Hindu Kush-Himalayas. EcoHealth, 4(3), 264-270.

Elalem, S., \& Pal, I. (2015). Mapping the vulnerability hotspots over Hindu-Kush Himalaya region to flooding disasters. Weather and Climate Extremes, 8, 46-58.

Ellis, E. C. (2015). Ecology in an anthropogenic biosphere. Ecological Monographs, 85(3), 287-331.

Esquinas-Alcázar, J. (2005). Protecting crop genetic diversity for food security: political, ethical and technical challenges. Nature Reviews Genetics, 6(12), 946-953.

Feng X., Fu B., Piao S., Wang S., Ciais P., Zeng Z., et al. (2016). Revevetation in China's Loss Plateau is approaching sustainable water resource limits. Nature Climate Change. https://doi.org/10. 1038/nclimate3092.
Foggin, M. (2012). Pastoralists and wildlife conservation in western China: Collaborative management within protected areas on the Tibetan Plateau. Pastoralism: Research, Policy and Practice, 2(1), 1.

Forrest, J., Wikramanayake, E., Shrestha, R., Areendran, G., Gyeltshen, K., Maheshwari, A., et al. (2012). Conservation and climate change: assessing the vulnerability of snow leopard habitat to tree line shift in the Himalaya. Biological Conservation (150), 129-135.

Frankham, R. (2005). Genetics and extinction. Biological Conservation, 126 (2), 131-140.

Gagic, V., Bartomeus, I., Jonsson, T., Taylor, A., Winqvist, C., Fischer, C., et al. (2015). Functional identity and diversity of animals predict ecosystem functioning better than species-based indices. Proceedings of the Royal Society of London B: Biological Sciences, 282 (1801), 20142620.

Gao, H., Ouyang, Z., Chen, S., \& van Koppen, C. S. A. (2013). Role of culturally protected forests in biodiversity conservation in Southeast China. Biodiversity and Conservation, 22(2), 531-544.

Gerlitz, J. Y., Hunzai, K., \& Hoermann, B. (2012). Mountain poverty in the Hindu-Kush Himalayas. Canadian Journal of Development Studies/Revue canadienne d'études du développement, 33(2), 250265

GoI. (2008). National action plan on climate change. Government of India, New Delhi.

GoI. (2016). National mission for sustaining the Himalayan ecosystem. Government of India, New Delhi.

GoI. (2017). National mission on Himalayan studies. Government of India, New Delhi.

Goldewijk, K. K., Beusen, A., \& Janssen, P. (2010). Long-term dynamic modeling of global population and built-up area in a spatially explicit way: HYDE 3.1. The Holocene. 1-9.

Goldewijk, K. K., Beusen, A., Van Drecht, G., \& De Vos, M. (2011). The HYDE 3.1 spatially explicit database of human-induced global land-use change over the past 12,000 years. Global Ecology and Biogeography, 20(1), 73-86.

Gorenflo, L. J., Romaine, S., Mittermeier, R. A., \& Walker-Painemilla, K. (2012). Co-occurrence of linguistic and biological diversity in biodiversity hotspots and high biodiversity wilderness areas. Proceedings of the National Academy of Sciences, 109(21), 80328037.

Grajal, A. (1999). Biodiversity and the nation state: Regulating access to genetic resources limits biodiversity research in developing countries. Conservation Biology, 13(1), 6-10.

Grêt-Regamey, A., Walz, A., \& Bebi, P. (2008). Valuing ecosystem services for sustainable landscape planning in Alpine regions. Mountain Research and Development, 28(2), 156-165.

Grêt-Regamey, A., Brunner, S. H., \& Kienast, F. (2012). Mountain ecosystem services: Who cares? Mountain Research and Development, 32(S1), S23-S34.

Groves, C. (2011). The taxonomy and phylogeny of Ailurus. In A. R. Glatston (Ed.). Red panda: Biology and conservation of the first panda (pp. 101-124). William Andrew.

Grumbine, R. E., \& Pandit, M. K. (2013). Threats from India's Himalaya dams. Science, 339(6115), 36-37.

Guangwei, C. (2002). Biodiversity in the Eastern Himalayas: Conservation through dialogue. Summary report of workshops on biodiversity conservation in the Hindu Kush-Himalayan ecoregion. International Centre for Integrated Mountain Development (ICIMOD).

Gupta, S. R., Upadhaya, M. P., \& Katsumoto, T. (1996). Status of plant genetic resources in Nepal. Paper presented at the 19th summer crops workshop, held at National Rice Research Programme, Parwanipur, Bara, Nepal, 27-29 February 1995. Parwanipur, Nepal: National Rice Research Programme. 
Gurung, H. (2004a). Mountain reflections, patterns and development. Kathmandu: Mandala Publications.

Gurung, P. C. (2004b). Terai arc landscape: A new paradigm in conservation and sustainable development. In Managing mountain protected areas: Challenges and responses for the 21st century (pp. 80-86). Andromeda, Colledara, Italy.

Gurung, D. B., \& Seeland, K. (2008). Ecotourism in Bhutan: Extending its benefits to rural communities. Annals of Tourism Research, 35 (2), 489-508.

Gurung, A., Bista, R., Karki, R., Shrestha, S., Uprety, D., \& Oh, S. E. (2013). Community-based forest management and its role in improving forest conditions in Nepal. Small-scale Forestry, 12(3), 377-388.

Haase, D., Schwarz, N., Strohbach, M., Kroll, F., \& Seppelt, R. (2012). Synergies, trade-offs, and losses of ecosystem services in urban regions: an integrated multiscale framework applied to the Leipzig-Halle Region. Germany. Ecology and Society, 17(3), 22.

Hamilton, L. S. (2015). When the sacred encounters economic development in mountains. George Wright Forum 32(2), 132-140.

Hart, R., Salick, J., Ranjitkar, S., \& Xu, J. (2014). Herbarium specimens show contrasting phenological responses to Himalayan climate. Proceedings of the National Academy of Sciences, 111(29), 10615-10619.

Hoffmann, M., Hilton-Taylor, C., Angulo, A., Böhm, M., Brooks, T. M., Butchart, S. H., et al. (2010). The impact of conservation on the status of the world's vertebrates. Science, 330(6010), 1503-1509.

Hoisington, D., Khairallah, M., Reeves, T., Ribaut, J. M., Skovmand, B., Taba, S., et al. (1999). Plant genetic resources: What can they contribute toward increased crop productivity?. Proceedings of the National Academy of Sciences, 96(11), 5937-5943.

Hoorn, C., Mosbrugger, V., Mulch, A., \& Antonelli, A. (2013). Biodiversity from mountain building. Nature Geoscience, 6(3), $154-154$.

Hua, Z. (2012). Biogeographical divergence of the Flora of Yunnan, Southwestern China initiated by the uplift of Himalaya and extrusion of Indochina block. PLoS ONE, 7(9), e45601. https:// doi.org/10.1371/journal.pone.0045601.

Hudson, A. M., Olsen, J. W., Quade, J., Lei, G., Huth, T. E., \& Zhang, H. (2016). A regional record of expanded Holocene wetlands and prehistoric human occupation from paleowetland deposits of the western Yarlung Tsangpo valley, southern Tibetan Plateau. Quaternary Research.

Hughes, C. E., \& Atchison, G. W. (2015). The ubiquity of alpine plant radiations: From the Andes to the Hengduan Mountains. New Phytologist, 207(2), 275-282.

Hughes, A. R., Inouye, B. D., Johnson, M. T., Underwood, N., \& Vellend, M. (2008). Ecological consequences of genetic diversity. Ecology Letters, 11(6), 609-623.

Hussain, A., Rasul, G., Mahapatra, B., \& Tuladhar, S. (2016). Household food security in the face of climate change in the Hindu-Kush Himalayan region. Food Security, 8(5), 921-937.

ICIMOD, WCD, GBPNIHESD, RECAST. (2017). Kangchenjunga landscape conservation and development strategy and regional cooperation framework. ICIMOD Working Paper 2017/2. Kathmandu: ICIMOD.

Immerzeel, W. W., Van Beek, L. P., \& Bierkens, M. F. (2010). Climate change will affect the Asian water towers. Science, 328(5984), 1382-1385.

Immerzeel, W. W., Pellicciotti, F., \& Bierkens, M. F. P. (2013). Rising river flows throughout the twenty-first century in two Himalayan glacierized watersheds. Nature Geoscience, 6(9), 742-745.

IUCN. (2005). Benefits beyond boundaries. In Proceeding of the Vth World Park Congress (Ix+306 pp.). Gland, Switzerland: IUCN; UK: Cambridge.
IUCN. (2016). The IUCN red list of threatened species. Version 2016-2. www.iucnredlist.org. Retrieved on 15 October 2016.

Ives, J. D., \& Messerli, B. (1989). The Himalayan dilemma: Reconciling development and conservation. Psychology Press.

Jain, A., Rai, S. C., \& Sharma, E. (2000). Hydro-ecological analysis of a sacred lake watershed system in relation to land-use/cover change from Sikkim Himalaya. CATENA, 40(3), 263-278.

Janecka, J. E., Zhang, Y., Li, D., Munkhtsog, B., Bayaraa, M., Galsandorj, N., et al. (2017). Range-wide snow leopard phylogeography supports three subspecies. Journal of Heredity, esx044.

Jantz, S. M., Barker, B., Brooks, T. M., Chini, L. P., Huang, Q., Moore, R. M., et al. (2015). Future habitat loss and extinctions driven by land-use change in biodiversity hotspots under four scenarios of climate-change mitigation. Conservation Biology, 29(4), 1122-1131.

Joshi, G., \& Negi, G. C. (2011). Quantification and valuation of forest ecosystem services in the Western Himalayan region of India. International Journal of Biodiversity Science, Ecosystem Services \& Management, 7(1), 2-11.

Joshi, P. K., Rawat, A., Narula, S., \& Sinha, V. (2012). Assessing impact of climate change on forest cover type shifts in Western Himalayan Eco-region. Journal of Forestry Research, 23(1), 75-80.

Kala, C. P. (2014). Deluge, disaster and development in Uttarakhand Himalayan region of India: Challenges and lessons for disaster management. International Journal of Disaster Risk Reduction, 8, $143-152$.

Kalita, P., Tag, H., Sarma, H. N., \& Das, A. K. (2014). Evaluation of nutritional potential of five unexplored wild edible food plants from Eastern Himalayan biodiversity hotspot region (India). International Journal of Biological, Food, Veterinary Agricultural Engineering, 8, 207-210.

Kandel, K., Huettmann, F., Suwal, M. K., Regmi, G. R., Nijman, V., Nekaris, K. A. I., et al. (2015). Rapid multi-nation distribution assessment of a charismatic conservation species using open access ensemble model GIS predictions: Red panda (Ailurus fulgens) in the Hindu-Kush Himalaya region. Biological Conservation, 181, 150 161.

Kandel, P., Gurung, J., Chettri, N., Ning, W., \& Sharma, E. (2016). Biodiversity research trends and gap analysis from a transboundary landscape. Eastern Himalayas. Journal of Asia-Pacific Biodiversity, 9(1), 1-10.

Kapos, V., Rhind, J., Edwards, M., Ravilious, C., Price, M. F., \& Butt, N. (2000). Developing a map of the world's mountain forests, Forests in sustainable mountain development: A state of knowledge report for 2000. Wallingford: Task Force on Forests in Sustainable Mountain Development; CABI Publishing. https://doi.org/10.1079/ 9780851994468.0004.

Karan, P. P. (2015). Land, Life, and Environmental Change in the Himalaya. In Spatial diversity and dynamics in resources and urban development (pp. 223-233). Netherlands: Springer.

Karmacharya, D. B., Thapa, K., Shrestha, R., Dhakal, M., \& Janecka, J. E. (2011). Noninvasive genetic population survey of snow leopards (Panthera uncia) in Kangchenjunga conservation area, Shey Phoksundo National Park and surrounding buffer zones of Nepal. BMC Research Notes, 4(1), 1.

Kassam, K. A., Bulbulshoev, U., \& Ruelle, M. (2011). Ecology of time: Calendar of the human body in the Pamir Mountains. Journal of Persianate Studies, 4(2), 146-170.

Katsnelson, A. (2016). Big science spenders. Nature, 537, S2.

Khadka, M., \& Verma, R. (2012). Gender and biodiversity management in the Greater Himalayas: Towards equitable mountain development. International Centre for Integrated Mountain Development (ICIMOD).

Khumbongmayum, A. D., Khan, M. L., \& Tripathi, R. S. (2005). Sacred groves of Manipur, northeast India: Biodiversity value, 
status and strategies for their conservation. Biodiversity and Conservation, 14(7), 1541-1582.

Klein, J. A., Harte, J., \& Zhao, X. Q. (2004). Experimental warming causes large and rapid species loss, dampened by simulated grazing, on the Tibetan Plateau. Ecology Letters, 7(12), 1170-1179.

Kohli, R. K., Dogra, K. S., Batish, D. R., \& Singh, H. P. (2004). Impact of invasive plants on the structure and composition of natural vegetation of northwestern Indian Himalayas. Weed Technology, $18,1296-1300$.

Körner, C. (2004). Mountain biodiversity, its causes and function. Ambio, 11-17.

Körner, C. (2007). Climatic treelines: Conventions, global patterns, causes. Erdkunde, 61, 316-324.

Körner, C., \& Ohsawa, M. (2005). Mountain system. Ecosystems and human well being, current states and trends. In Millennium ecosystem assessment. Washington, DC: Island.

Kubiszewski, I., Costanza, R., Dorji, L., Thoennes, P., \& Tshering, K. (2013). An initial estimate of the value of ecosystem services in Bhutan. Ecosystem Services, 3, e11-e21.

Kubiszewski, I., Anderson, S. J., Costanza, R., \& Sutton, P. C. (2016). The future of ecosystem services in Asia and the Pacific. Asia \& the Pacific Policy Studies, 3(3), 389-404.

La Sorte, F. A., \& Jetz, W. (2010). Projected range contractions of montane biodiversity under global warming. Proceedings of the Royal Society of London B: Biological Sciences, rspb20100612.

Li, J., McCarthy, T. M., Wang, H., Weckworth, B. V., Schaller, G. B., Mishra, C., et al. (2016). Climate refugia of snow leopards in High Asia. Biological Conservation, 203, 188-196.

Liu, Y. P., Wu, G. S., Yao, Y. G., Miao, Y. W., Luikart, G., Baig, M., et al. (2006). Multiple maternal origins of chickens: out of the Asian jungles. Molecular Phylogenetics and Evolution, 38(1), 12-19.

Liu, D., Chen, Y., Cai, W., Dong, W., Xiao, J., Chen, J., et al. (2014). The contribution of China's grain to green program to carbon sequestration. Landscape Ecology, 29(10), 1675-1688.

Luck, G. W., Kai, C., \& Fay, J. P. (2009). Protecting ecosystem services and biodiversity in the world's watersheds. Conservation Letters, 179-188.

Luo, C., Xu, G., Chao, Z., Wang, S., Lin, X., Hu, Y., et al. (2010). Effect of warming and grazing on litter mass loss and temperature sensitivity of litter and dung mass loss on the Tibetan plateau. Global Change Biology, 16(5), 1606-1617.

MA. (2005). Millennium ecosystem assessment findings. Millennium Ecosystem Assessment

Maharana, I., Rai, S. C., \& Sharma, E. (2000). Environmental economics of the Khangchendzonga National Park in the Sikkim Himalaya, India. GeoJournal, 50(4), 329-337.

Maikhuri, R. K., Rao, K. S., \& Semwal, R. L. (2001). Changing scenario of Himalayan agroecosystems: Loss of agrobiodiversity, an indicator of environmental change in Central Himalaya, India. The Environmentalist, 21(1), 23-39.

Mandel, J. R., Dechaine, J. M., Marek, L. F., \& Burke, J. M. (2011). Genetic diversity and population structure in cultivated sunflower and a comparison to its wild progenitor. Helianthus Annuus $L$ Theoretical and Applied Genetics, 123(5), 693-704.

Måren, I., Bhattarai, K. R., \& Chaudhary, R. P. (2013). Forest ecosystem services and biodiversity: The resource flux from forests to farm in the Himalayas. Environmental Conservation, 41(1), 7383. https://doi.org/10.1017/s0376892913000258.

Maselli, D. (2012). Promoting sustainable mountain development at the global level: The Swiss development cooperation's involvement. Mountain Research and Development, 32(S1), S64-S70.

Maxwell, S. L., Fuller, R. A., Brooks, T. M., \& Watson, J. E. (2016) Biodiversity: The ravages of guns, nets and bulldozers. Nature, 536, 143-145.
Mehra, A., Bajpai, O., \& Joshi, H. (2014). Diversity, utilization and sacred values of ethno-medicinal plants of Kumaun Himalaya. Tropical Plant Research, 1, 80-86.

Menon, V. (1996). Under Siege: Poaching and protection of greater one-horned rhinoceroses in India. Cambridge, UK: Traffic International.

Menon, S., Latif Khan, M., Paul, A., \& Peterson, A. T. (2012). Rhododendron species in the Indian Eastern Himalayas: New approaches to understanding rare plant species distributions.

Metzger, M. J., Bunce, R. G., Jongman, R. H., Sayre, R., Trabucco, A., \& Zomer, R. (2013). A high-resolution bioclimate map of the world: a unifying framework for global biodiversity research and monitoring. Global Ecology and Biogeography, 22(5), 630-638.

Miehe, G., Miehe, S., \& Schlütz, F. (2009). Early human impact in the forest ecotone of southern High Asia (Hindu Kush, Himalaya). Quaternary Research, 71(3), 255-265.

Miehe, G., Miehe, S., Böhner, J., Kaiser, K., Hensen, I., Madsen, D., et al. (2014). How old is the human footprint in the world's largest alpine ecosystem? A review of multiproxy records from the Tibetan Plateau from the ecologists' viewpoint. Quaternary Science Reviews, 86, 190-209.

Miehe, G., Pendry, C., \& Chaudhary, R. P. (2015a). Nepal-An introduction to the natural history, ecology and human environment in the Himalayas: A companion to the Flora of Nepal. Edinburgh, UK: Royal Botanic Garden.

Miehe, G., Miehe, S., Bohner, J., Baumler, R., Ghimire, S. K. Bhattarai, K., et al. (2015b). Vegetation ecology. Nepal-An introduction to the natural history, ecology and human environment in the Himalayas: A companion to the Flora of Nepal (pp. 385472). Edinburgh, UK: Royal Botanic Garden.

Milleville, R. D. (2002). The Rhododendrons of Nepal (p. 136). Lalitpur: Himal Books.

Mittermeier, R. A., Gil, R. P., Hoffman, M., et al. (2004). Hotspots revisited. Earth's biologically richest and most endangered terrestrial ecoregions. Mexico City: CEMEX/Agrupación Sierra Madre.

Mittermeier, R. A., Turner, W. R., Larsen, F. W., Brooks, T. M., \& Gascon, C. (2011). Global biodiversity conservation: the critical role of hotspots. In Biodiversity Hotspots (pp. 3-22). Berlin, Heidelberg: Springer.

Mittermeier, R. A., van Dijk, P. P., Rhodin, A. G., \& Nash, S. D. (2015). Turtle hotspots: an analysis of the occurrence of tortoises and freshwater turtles in biodiversity hotspots, high-biodiversity wilderness areas, and turtle priority areas. Chelonian Conservation and Biology, 14(1), 2-10.

MoAF. (2014). National biodiversity strategies and action plan, Bhutan 2014. Ministry of Agriculture and Forest, Royal Government of Bhutan, Thimphu, Bhutan.

MoAF. (2016). Forest facts and figures. Ministry of Agriculture and Forest, Royal Government of Bhutan, Thimphu, Bhutan.

MoCC. (2015). National forest policy 2015. Ministry of Climate Change, Government of Pakistan, Islamabad, Pakistan.

MoECF. (2011). National biodiversity strategy and action planMyanmar. Ministry of Environmental Conservation and Forestry, Myanmar.

MoEF. (2004). National biodiversity strategy and action plan for Bangladesh. Ministry of Environment and Forests, Government of the People's Republic of Bangladesh, Dhaka.

MoEF. (2008). National biodiversity action plan. Ministry of Environment and Forests, Government of India.

MoEF. (2014). India's fifth national report to the convention on biological diversity. Ministry of Environment and Forests, Government of India.

MoEPC. (2014). China's fifth national report on the implementation of the convention on biological diversity. The Ministry of Environmental Protection of Cal Protection of China. 
MoFSC. (2014). Nepal's 5th national report to convention on biological diversity. Ministry of Forests and Soil Conservation, Government of Nepal.

MoFSC. (2015a). Strategy and action plan 2015-2025, Terai Arc Landscape, Nepal. Ministry of Forests and Soil Conservation, Singha Durbar, Kathmandu, Nepal.

MoFSC. (2015b). Strategy and action plan 2016-2025, Chitwan-Annapurna Landscape, Nepal. Ministry of Forests and Soil Conservation, Singha Durbar, Kathmandu, Nepal.

MoFSC. (2016). Conservation landscapes of Nepal. Ministry of Forest and Soil Conservation. Government of Nepal, Kathmandu, Nepal.

MoFSC. (2017). Western mountain landscape level programme's feasibility study and strategic plan. Department of Forests, Ministry of Forests and Soil Conservation, Nepal.

Molden, D. J., Vaidya, R. A., Shrestha, A. B., Rasul, G., \& Shrestha, M. S. (2014a). Water infrastructure for the Hindu Kush Himalayas. International Journal of Water Resources Development, 30(1), 60-77.

Molden, D., Verma, R., \& Sharma, E. (2014b). Gender equality as a key strategy for achieving equitable and sustainable development in mountains: The case of the Hindu Kush-Himalayas. Mountain Research and Development, 34(3), 297-300.

Molden, D. J., Shrestha, A. B., Nepal, S., \& Immerzeel, W. W. (2016). Downstream implications of climate change in the Himalayas. In Water security, climate change and sustainable development (pp. 65-82). Singapore: Springer.

Mora, C., Caldwell, I. R., Caldwell, J. M., Fisher, M. R., Genco, B. M., \& Running, S. W. (2015). Suitable days for plant growth disappear under projected climate change: potential human and biotic vulnerability. PLoS Biology, 13(6), e1002167.

Mukerji, A. K. (2006). Evolution of good governance through forest policy reform in India. In P. Bhattacharya, A. K. Kandya, \& K. N. Krishna Kumar (Eds.), JFM at crossroads: Future strategy and action programme for institutionalizing community forestry, Workshop PrePrints (pp. 17-24).

Mukherji, A., Molden, D., Nepal, S., Rasul, G., \& Wagnon, P. (2015). Himalayan waters at the crossroads: Issues and challenges. International Journal of Water Resources Development, 31(2), 151-160.

Myers, N., Mittermeier, R. A., Mittermeier, C. G., Da Fonseca, G. A., $\&$ Kent, J. (2000). Biodiversity hotspots for conservation priorities. Nature, 403(6772), 853-858.

Naidoo, R., Balmford, A., Costanza, R., Fisher, B., Green, R. E., Lehner, B., et al. (2008). Global mapping of ecosystem services and conservation priorities. Proceedings of the National Academy of Sciences, 105(28), 9495-9500.

NCD. (2004) Bhutan biological conservation complex: A landscape conservation plan-Way forward. Bhutan: Nature Conservation Division (NCD) and WWF.

Negi, C. S. (2005). Socio-cultural and ethnobotanical value of a sacred forest, Thal Ke Dhar, central Himalaya. Indian Journal of Traditional Knowledge, 4(2), 190-198.

Nepal, S. K. (1997). Sustainable tourism, protected areas and livelihood needs of local communities in developing countries. The International Journal of Sustainable Development \& World Ecology, 4(2), 123-135.

Nepal, S. K. (2013). Mountain tourism and climate change: Implications for the Nepal Himalaya. Nepal Tourism and Development Review, 1(1), 1-14.

Nepal, S., Flügel, W. A., \& Shrestha, A. B. (2014a). Upstream-downstream linkages of hydrological processes in the Himalayan region. Ecological Processes, 3(1), 1.

Nepal, S., Krause, P., Flügel, W. A., Fink, M., \& Fischer, C. (2014b). Understanding the hydrological system dynamics of a glaciated alpine catchment in the Himalayan region using the J2000 hydrological model. Hydrological Processes, 28(3), 1329-1344.
Ning, W., Ismail, M., Joshi, S., Qamar, F. M., Phuntsho, K., Weikang, Y., et al. (2014). Understanding the transboundary Karakoram-Pamir landscape. Kathmandu, Nepal: ICIMOD.

Notter, D. R. (1999). The importance of genetic diversity in livestock populations of the future. Journal of animal science, 77(1), 61-69.

Oli, K. P., Chaudhary, S., \& Sharma, U. R. (2013). Are governance and management effective within protected areas of the Kanchenjunga landscape (Bhutan, India and Nepal). Parks, 19(1), 25-36.

Olson, D. M., \& Dinerstein, E. (2002). The Global 200: Priority ecoregions for global conservation. Annals of the Missouri Botanical Garden, 199-224.

Ouyang, Z., Zheng, H., Xiao, Y., Polasky, S., Liu, J., Xu, W., et al. (2016). Improvements in ecosystem services from investments in natural capital. Science, 352(6292), 1455-1459.

Pai, R., \& Datta, S. (2006). Measuring milestones. In Proceedings of the National Workshop on Joint Forest Management (JFM), 17 October 2006, New Delhi.

Panday, P. K., Williams, C. A., Frey, K. E., \& Brown, M. E. (2014). Application and evaluation of a snowmelt runoff model in the Tamor River basin, Eastern Himalaya using a Markov Chain Monte Carlo (MCMC) data assimilation approach. Hydrological Processes, 28(21), 5337-5353.

Pandit, M. K., \& Grumbine, R. E. (2012). Potential effects of ongoing and proposed hydropower development on terrestrial biological diversity in the Indian Himalaya. Conservation Biology, 26(6), 1061-1071.

Pandit, M. K., Sodhi, N. S., Koh, L. P., Bhaskar, A., \& Brook, B. W. (2007). Unreported yet massive deforestation driving loss of endemic biodiversity in Indian Himalaya. Biodiversity and Conservation, 16(1), 153-163.

Pandit, M. K., Manish, K., \& Koh, L. P. (2014). Dancing on the roof of the world: ecological transformation of the Himalayan landscape. BioScience, 64(11), 980-992.

Pant, K. P., Rasul, G., Chettri, N., Rai, K. R., \& Sharma, E. (2012). Value of forest ecosystem services: a quantitative estimation from the Kangchenjunga landscape in eastern Nepal. ICIMOD Working Paper, (2012/5).

Paudyal, K., Baral, H., Burkhard, B., Bhandari, S. P., \& Keenan, R. J. (2015). Participatory assessment and mapping of ecosystem services in a data-poor region: case study of community-managed forests in central Nepal. Ecosystem Services, 13, 81-92.

Paul, S., \& Chakrabarti, S. (2011). Socio-economic issues in forest management in India. Forest Policy and Economics, 13(1), 55-60.

Pei, S. (1995). Banking on biodiversity. Report on the regional consultations on biodiversity assessment in the Hindu Kush Himalaya. Kathmandu, Nepal: ICIMOD.

Pereira, H. M., Leadley, P. W., Proenca, V., Alkemade, R., et al. (2010). Scenarios for global biodiversity in the 21 st century. Science, 330, 1496-1501.

Posch, E., Bell, R., Weidinger, J. T., \& Glade, T. (2015). Geomorphic processes, rock quality and solid waste management-examples from the Mt. Everest region of Nepal. Journal of Water Resource and Protection, 7(16), 1291.

Pradhan, S., Saha, G. K., \& Khan, J. A. (2001). Ecology of the red panda Ailurus fulgens in the Singhalila National Park, Darjeeling, India. Biological Conservation, 98(1), 11-18.

Pradhan, R., Argent, G., \& McFarlane, M. (2003). Wild rhododendrons of Bhutan. In Rhododendrons in horticulture and science. Papers presented at the International Rhododendron Conference, Edinburgh, UK, 17-19 May 2002. (pp. 37-41). Edinburgh: Royal Botanic Garden.

Pradhan, N. M., Wegge, P., Moe, S. R., \& Shrestha, A. K. (2008). Feeding ecology of two endangered sympatric megaherbivores: Asian elephant Elephas maximus and greater one-horned rhinoceros 
Rhinoceros unicornis in lowland Nepal. Wildlife Biology, 14(1), $147-154$.

Quyang, H. (2009). The Himalayas-Water storage under threat. Sustainable Mountain Development, 56, 3-5.

Rai, S. C., Sharma, E., \& Sundriyal, R. C. (1994). Conservation in the Sikkim Himalaya: traditional knowledge and land-use of the Mamlay watershed. Environmental Conservation, 21(01), 30-34.

Ramesh, K. V., \& Goswami, P. (2007). Reduction in temporal and spatial extent of the Indian summer monsoon. Geophysical Research Letters, 34(23).

Ranjitkar, S., Luedeling, E., Shrestha, K. K., Guan, K., \& Xu, J. (2013). Flowering phenology of tree rhododendron along an elevation gradient in two sites in the Eastern Himalayas. International Journal of Biometeorology, 57(2), 225-240.

Rao, M., Rabinowitz, A., \& Khaing, S. T. (2002). Status review of the protected-area system in Myanmar, with recommendations for conservation planning. Conservation Biology, 16(2), 360-368.

Rao, M., Zaw, T., Htun, S., \& Myint, T. (2011). Hunting for a living: Wildlife trade, rural livelihoods and declining wildlife in the Hkakaborazi National Park, North Myanmar. Environmental Management, 48(1), 158-167.

Rasul, G. (2014). Food, water, and energy security in South Asia: A nexus perspective from the Hindu Kush Himalayan region. Environmental Science \& Policy, 39, 35-48.

Rasul, G., \& Sharma, B. (2015). The nexus approach to water-energyfood security: An option for adaptation to climate change. Climate Policy, 1-21.

Rasul, G., Chettri, N., \& Sharma, E. (2011a). Framework for valuing ecosystem services in the Himalayas. ICIMOD.

Rasul, G., Thapa, G. B., \& Karki, M. B. (2011b). Comparative analysis of evolution of participatory forest management institutions in South Asia. Society \& Natural Resources, 24(12), 1322-1334.

Richter, B., Matthews, R., Harrison, D., \& Wigington, R. (2003). Ecologically sustainable water management: Managing river flows for ecological integrity. Ecological Applications, 13, 206-224.

Rodríguez-Rodríguez, D., Bomhard, B., Butchart, S. H., \& Foster, M. N. (2011). Progress towards international targets for protected area coverage in mountains: A multi-scale assessment. Biological Conservation, 144(12), 2978-2983.

Rounsevell, M. D., Pedroli, B., Erb, K. H., Gramberger, M., Busck, A. G., Haberl, H., et al. (2012). Challenges for land system science. Land Use Policy, 29(4), 899-910.

Salgotra, R. K., Gupta, B. B., Bhat, J. A., \& Sharma, S. (2015). Genetic diversity and population structure of basmati rice (Oryza sativa L.) germplasm collected from North Western Himalayas using trait linked SSR markers. PloS ONE, 10(7), e0131858.

Salick, J., Amend, A., Anderson, D., Hoffmeister, K., Gunn, B., \& Zhendong, F. (2007). Tibetan sacred sites conserve old growth trees and cover in the eastern Himalayas. Biodiversity and Conservation, 16(3), 693-706.

Sandhu, H., \& Sandhu, S. (2014). Linking ecosystem services with the constituents of human well-being for poverty alleviation in eastern Himalayas. Ecological Economics, 107, 65-75.

Sarkar, S. (2011). Climate change and disease risk in the Himalayas. Himalayan Journal of Sciences, 6(8), 7-8.

Savillo, I. T. (2009). Present status of Ramsar sites in Nepal. International Journal of Biodiversity and Conservation, 1(5), 146-150.

Sayer, J. (2009). Reconciling conservation and development: Are landscapes the answer? Biotropica, 41(6), 649-652.

Sayer, J., Sunderland, T., Ghazoul, J., Pfund, J. L., Sheil, D., Meijaard, E., et al. (2013). Ten principles for a landscape approach to reconciling agriculture, conservation, and other competing land uses. Proceedings of the National Academy of Sciences, 110(21), 8349-8356.
Schaich, H., Bieling, C., \& Plieninger, T. (2010). Linking ecosystem services with cultural landscape research. Gaia-Ecological Perspectives for Science and Society, 19(4), 269-277.

Schaller, G. B. (1998). Wildlife of the Tibetan steppe. Chicago: University of Chicago Press.

Schild, A. (2008). The case of the Hindu Kush-Himalayas: ICIMOD's position on climate change and mountain systems. Mountain Research and Develpment, 28(3/4), 328-331.

Secretariat of the Convention on Biological Diversity. (2014) Global Biodiversity Outlook 4 (155 pp.). Montréal.

Shakya, B., Uddin, K., Chettri, N., Bajracharya, B., \& Sharma, E. (2011) Use of geo-spatial tools in the management of potential habitats outside the protected areas in the transboundary Brahmaputra Salween landscape. In Contribution of ecosystem restoration to the objectives of the CBD and a healthy planet for all people, Abstracts of posters presented at the 15th meeting of the Subsidiary Body on Scientific, Technical and Technological Advice of the Convention on Biological Diversity, 7-11 November 2011, Montreal, Canada, Technical Series No. 62, pp 98-100. Montreal, Canada: Secretariat of the Convention on Biological Diversity.

Sharma, E., \& Chettri, N. (2005). ICIMOD's transboundary biodiversity management initiative in the Hindu Kush-Himalayas. Mountain Research and Development, 25(3), 280-283.

Sharma, E., Bhuchar, S., Xing, M., \& Kothyari, B. P. (2007a). Land use change and its impact on hydro ecological linkages in Himalayan watersheds. Tropical Ecology, 48(2), 151-161.

Sharma, R., Xu, J., \& Sharma, G. (2007b). Traditional agroforestry in the Eastern Himalayan region: Land management system supporting ecosystem services. Tropical Ecology, 48(2), 189.

Sharma, E., Chettri, N., Gurung, J., \& Shakya, B. (2007c). Landscape approach in biodiversity conservation: A regional cooperation framework for implementation of the convention on biological diversity in Kangchenjunga landscape (p. 29). Kathmandu, Nepal: ICIMOD.

Sharma E., Chettri N., Tse-ring K., Shrestha A. B., Jing F., Mool P., et al. (2009). Climate change impacts and vulnerability in the Eastern Himalayas (p. 27). Kathmandu, Nepal: ICIMOD.

Sharma, E., Chettri, N., \& Oli, K. P. (2010). Mountain biodiversity conservation and management: A paradigm shift in policies and practices in the Hindu Kush-Himalayas. Ecological Research, 25 (5), 909-923.

Sharma, B., Rasul, G., \& Chettri, N. (2015). The economic value of wetland ecosystem services: Evidence from Koshi Tappu wildlife reserve. Nepal. Ecosystem Services., 12, 84-93.

Sharma, B. K., Haokip, T. P., \& Sharma, S. (2016). Loktak Lake, Manipur, northeast India: a Ramsar site with rich rotifer (Rotifera: Eurotatoria) diversity and its meta-analysis. International Journal of Aquatic Biology, 4(2).

Sherpa, M., \& Norbu, U. P. (1999). Linking protected areas for ecosystem conservation: A case study from Bhutan. Parks, 9, 35-45.

Sherpa, L. N., Peniston, B., Lama, W., \& Richard, C. (2003). Hands around Everest: Transboundary cooperation for conservation and sustainable livelihoods. Kathmandu, Nepal: International Centre for Integrated Mountain Development (ICIMOD).

Shrestha, U. B., Gautam, S., \& Bawa, K. S. (2012). Widespread climate change in the Himalayas and associated changes in local ecosystems. PLoS ONE, 7(5), e36741.

Shu D. J. (2005). Flora of China. Rhododendron. Vol 15-260-445. http://flora.huh.harvard.edu/china/PDF/PDF14/Rhododendron.pdf. Retrieved 21 September 2016.

Simpson, B. B., \& Ogorzaly, M. C. (1986). Economic botany: Plants in our world. New York: McGraw-Hill.

Singh, S. P. (2002). Balancing the approaches of environmental conservation by considering ecosystem services as well as biodiversity. Current Science, 82(11), 1331-1335. 
Singh, K. K. (2009). Notes on the Sikkim Himalayan rhododendrons: A taxa of great conservation importance. Turkish Journal of Botany, 33(4), 305-310.

Singh, B., \& Borthakur, S. K. (2015). Phenology and geographic extension of lycophyta and fern flora in nokrek biosphere reserve of Eastern Himalaya. Proceedings of the National Academy of Sciences, India Section B: Biological Sciences, 85(1), 291-301.

Singh, S. P., Singh, V., \& Skutsch, M. (2010). Rapid warming in the Himalayas: Ecosystem responses and development options. Climate and Development, 2(3), 221-232.

Singh, S. P., Bassignana-Khadka, I., Karky, B. S., \& Sharma, E. (2011).Climate change in the Hindu Kush-Himalayas: the state of current knowledge. International Centre for Integrated Mountain Development (ICIMOD).

Sinha, B., \& Mishra, S. (2015). Ecosystem services valuation for enhancing conservation and livelihoods in a sacred landscape of the Indian Himalayas. International Journal of Biodiversity Science, Ecosystem Services \& Management, 11(2), 156-167.

Song, X., Peng, C., Zhou, G., Jiang, H., \& Wang, W. (2014). Chinese grain for green program led to highly increased soil organic carbon levels: A meta-analysis. Scientific Reports, 4, 4460.

Song, W., Deng, X., Liu, B., Li, Z., \& Jin, G. (2015). Impacts of grain-for-green and grain-for-blue policies on valued ecosystem services in Shandong Province, China. Advances in Meteorology, 2015, 1-10.

Sunam, R. K., Bishwokarma, D., \& Darjee, K. B. (2015). Conservation Policy Making in Nepal: Problematising the Politics of Civic Resistance. Conservation and Society, 13(2), 179.

Taylor, K., \& Lennon, J. (2011). Cultural landscapes: a bridge between culture and nature? International Journal of Heritage Studies, 17 (6), 537-554.

Telwala, Y., Brook, B. W., Manish, K., \& Pandit, M. K. (2f013). Climate-induced elevational range shifts and increase in plant species richness in a Himalayan biodiversity epicentre. PLoS One, 8 (2), e57103.

Tesfaye, M., Dufault, N. S., Dornbusch, M. R., Allan, D. L., Vance, C. P., \& Samac, D. A. (2003). Influence of enhanced malate dehydrogenase expression by alfalfa on diversity of rhizobacteria and soil nutrient availability. Soil Biology \& Biochemistry, 35(8), 1103-1113.

Tews, J., Brose, U., Grimm, V., Tielbörger, K., Wichmann, M. C., Schwager, M., et al. (2004). Animal species diversity driven by habitat heterogeneity/diversity: the importance of keystone structures. Journal of Biogeography, 31(1), 79-92.

Thapa, K., Nepal, S., Thapa, G., Bhatta, S. R., \& Wikramanayake, E. (2013). Past, present and future conservation of the greater one-horned rhinoceros Rhinoceros unicornis in Nepal. Oryx, 47 (03), 345-351.

Thompson, C. (2009). New Species Discoveries-the Eastern Himalayas where Worlds Collide.

Thompson, M., \& Warburton, M. (1985). Decision making under contradictory certainties: how to save the Himalayas when you can't find out what's wrong with them. Journal of Applied Systems Analysis, 12(1), 3-34.

Thuiller, W., Albert, C., Araújo, M. B., Berry, P. M., Cabeza, M., Guisan, A., et al. (2008). Predicting global change impacts on plant species' distributions: future challenges. Perspectives in Plant Ecology, Evolution and Systematics, 9(3), 137-152.

Tilman, D., Fargione, J., Wolff, B., D'Antonio, C., Dobson, A., Howarth, R., et al. (2001). Forecasting agriculturally driven global environmental change. Science, 292(5515), 281-284.

Tremblay, M. M., Fox, M., Schmidt, J. L., Tripathy-Lang, A., Wielicki, M. M., Harrison, T. M., et al. (2015). Erosion in southern Tibet shut down at $\sim 10 \mathrm{Ma}$ due to enhanced rock uplift within the
Himalaya. Proceedings of the National Academy of Sciences, 112 (39), 12030-12035.

Turin, M. (2005). Language endangerment and linguistic rights in the Himalayas: A case study from Nepal. Mountain Research and Development, 25(1), 4-9.

Uchida, E., Xu, J., \& Rozelle, S. (2005). Grain for green: cost-effectiveness and sustainability of China's conservation set-aside program. Land Economics, 81(2), 247-264.

Uddin, K., Chaudhary, S., Chettri, N., Kotru, R., Murthy, M., Chaudhary, R. P., et al. (2015). The changing land cover and fragmenting forest on the Roof of the World: A case study in Nepal's Kailash Sacred Landscape. Landscape and Urban Planning, 141, 1-10.

UN. (1992). Report of the United Nations Conference on Environment and Development. Rio de Janeiro 3-14 June 1992. A/CONF.151/26 (Vol. 1).

Upadhaya, S., Chalise, L., \& Pandel, R. P. (2009). High altitude Ramsar sites of Nepal. The Initiation, 3, 135-148.

Upadhyay, T. P., Sankhayan, P. L., \& Solberg, B. (2005). A review of carbon sequestration dynamics in the Himalayan region as a function of land-use change and forest/soil degradation with special reference to Nepal. Agriculture, Ecosystems \& Environment, 105 (3), 449-465.

Uprety, Y., Poudel, R. C., Gurung, J., Chettri, N., \& Chaudhary, R. P. (2016). Traditional use and management of NTFPs in Kangchenjunga Landscape: implications for conservation and livelihoods. Journal of Ethnobiology and Ethnomedicine, 12(1), 1.

Valley, H. P. (2003). Upward shift of Himalayan pine in western Himalaya. India. Current Science, 85(1), 135.

Waldron, A., Mooers, A. O., Miller, D. C., Nibbelink, N., Redding, D., Kuhn, T. S., et al. (2013). Targeting global conservation funding to limit immediate biodiversity declines. Proceedings of the National Academy of Sciences, 110(29), 12144-12148.

Wang, L., Young, S. S., Wang, W., Ren, G., Xiao, W., Long, Y., et al. (2016). Conservation priorities of forest ecosystems with evaluations of connectivity and future threats: Implications in the Eastern Himalaya of China. Biological Conservation, 195, 128-135.

Watson, J. E., Jones, K. R., Fuller, R. A., Marco, M. D., Segan, D. B., Butchart, S. H., et al. (2016). Persistent disparities between recent rates of habitat conversion and protection and implications for future global conservation targets. Conservation Letters, 9(6), 413421.

WCMC-UNEP. (2002). Mountains of the World-Dataset. World Conservation Monitoring Center-UNEP. Cambridge, U.K. https:// www.arcgis.com/home/item.html?id= a068913914cd4fecb302b9207a532d1a.

Wei, F., Feng, Z., Wang, Z., \& Hu, J. (1999). Current distribution, status and conservation of wild red pandas Ailurus fulgens in China. Biological Conservation, 89(3), 285-291.

Westman, W. E. (1977). How much are nature's services worth? Science, 197(4307), 960-964.

Wieringa, M. J., \& Morton, A. G. (1996). Hydropower, adaptive management, and biodiversity. Environmental Management, 20(6), 831-840.

Wikramanayake, E. D., Dinerstein, E., Robinson, J. G., Karanth, U., Rabinowitz, A., Olson, D., et al. (1998). An Ecology-Based Method for Defining Priorities for Large Mammal Conservation: The Tiger as Case Study. Conservation Biology, 12(4), 865-878.

Wikramanayake, E. D., McKnight, M., Dinerstein, E., Joshi, A., Gurung, B., \& Smith, J. L. D. (2004). Designing a conservation landscape for tigers in human-dominated environments. Conservation Biology, 18, 839-844.

Wikramanayake, E., Dinerstein, E., Seidensticker, J., Lumpkin, S., Pandav, B., Shrestha, M., et al. (2011). A landscape-based 
conservation strategy to double the wild tiger population. Conservation Letters, 4(3), 219-227.

Wilkes, A. (2008). Towards mainstreaming climate change in grassland management policies and practices on the Tibetan Plateau (No. 67). Working paper.

Wilson, K. A., Auerbach, N. A., Sam, K., Magini, A. G., Moss, A. S. L., Langhans, S. D., et al. (2016). Conservation Research Is Not Happening Where It Is Most Needed. PLoS Biology, 14(3), e1002413.

Xu, J., \& Grumbine, R. E. (2014a). Building ecosystem resilience for climate change adaptation in the Asian highlands. Wiley Interdisciplinary Reviews: Climate Change, 5(6), 709-718.

Xu, J., \& Grumbine, R. E. (2014b). Integrating local hybrid knowledge and state support for climate change adaptation in the Asian highlands. Climatic Change, 124, 93-104.

Xu, J., Yang, Y., Ayad, W. G., \& Eyzaguirre, P. B. (2001). Genetic Diversity in Taro (Colocasia esculenta Schott, Araceae) in China: An Ethnobotanical and Genetic Approach. Economic Botany, 55(1), $14-31$.

Xu, J., Ma, E., Tashi, D., Fu, Y., Lu, Z., \& Melick, D. (2005). Integrating Sacred Knowledge for Conservation: Cultures and Landscapes in Southwest China. Ecology and Society, 10(2), 7.

Xu, J., Sharma, R., Fang, J., \& Xu, Y. (2008). Critical linkages between land-use transition and human health in the Himalayan region. Environment International, 34(2), 239-247.

$\mathrm{Xu}$, J., Grumbine, R. E., Shrestha, A., Eriksson, M., Yang, X., Wang, Y. U. N., et al. (2009a). The melting Himalayas: cascading effects of climate change on water, biodiversity, and livelihoods. Conservation Biology, 23(3), 520-530.
Xu, J. C., Lebel, L., \& Sturgeon, J. (2009b). Functional links between biodiversity, livelihoods and culture in a Hani swidden landscape in Southwest China. Ecology and Society, 14(2), 20.

$\mathrm{Xu}$, J., White, A., \& Lele, U. J. (2010). China's forest tenure reforms: Impacts and implications for choice, conservation, and climate change. Rights and Resources Initiative.

Yonzon, P. B. (1989). Ecology and conservation of the red panda in the Nepal-Himalayas (Doctoral dissertation, University of Maine).

Ziv, G., Baran, E., Nam, S., Rodríguez-Iturbe, I., \& Levin, S. A. (2012). Trading-off fish biodiversity, food security, and hydropower in the Mekong River Basin. Proceedings of the National Academy of Sciences, 109(15), 5609-5614.

Zomer, R., \& Oli, K. P. (Eds.). (2011). Kailash Sacred Landscape Conservation Initiative- Feasibility assessment report. Kathmandu: ICIMOD.

Zomer, R. J., Trabucco, A., Metzger, M. J., Wang, M., Oli, K. P., \& $\mathrm{Xu}$, J. (2014). Projected climate change impacts on spatial distribution of bioclimatic zones and ecoregions within the Kailash Sacred Landscape of China, India. Nepal. Climatic change, 125(34), 445-460.

Zomer, R. J., Xu, J., Wang, M., Trabucco, A., \& Li, Z. (2015). Projected impact of climate change on the effectiveness of the existing protected area network for biodiversity conservation within Yunnan Province, China. Biological Conservation, 184, 335-345.

Zomer, R. J., Wang, M., Trabucco, A., \& Xu, J. C. (2016). Projected climate change impact on hydrology, bioclimatic conditions and terrestrial ecosystems in the Asian highlands. (ICRAF Working Paper 222). World Agroforestry Centre East and Central Asia, Kunming, China. 56 pp.
Open Access This chapter is licensed under the terms of the Creative Commons Attribution 4.0 International License (http:// creativecommons.org/licenses/by/4.0/), which permits use, sharing, adaptation, distribution and reproduction in any medium or format, as long as you give appropriate credit to the original author(s) and the source, provide a link to the Creative Commons license and indicate if changes were made.
The images or other third party material in this chapter are included in the chapter's Creative Commons license, unless indicated otherwise in a credit line to the material. If material is not included in the chapter's Creative Commons license and your intended use is not permitted by statutory regulation or exceeds the permitted use, you will need to obtain permission directly from the copyright holder. 